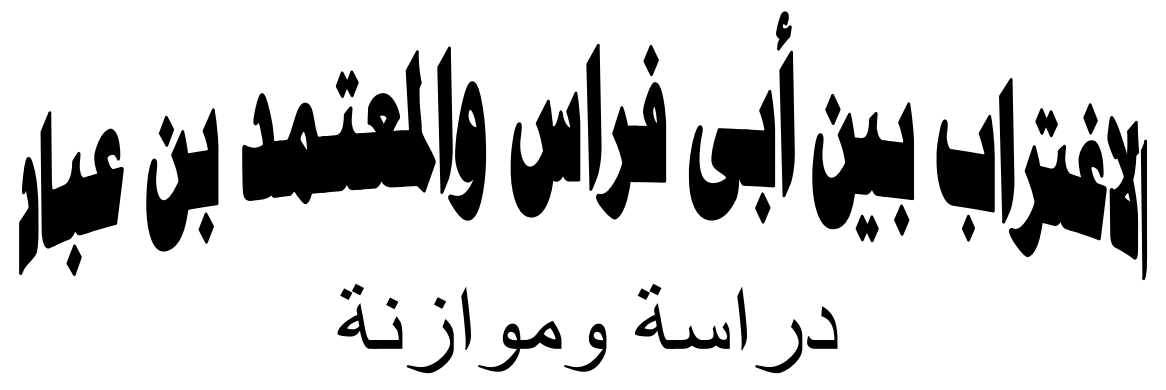

$$
\begin{aligned}
& \text { دكــتور } \\
& \text { عمر عبد العزيز الحسينى } \\
& \text { مدرس الأدب و النقا } \\
& \text { بجامعة الأز هر }
\end{aligned}
$$


الاغتراب بين أبى فراس والمعتمد بن عباد - دراسة وموازنة

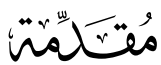

الحمد الله رب العـالمين.... والصـلاة والسـلام على رسـول الله... وعلى آلـه

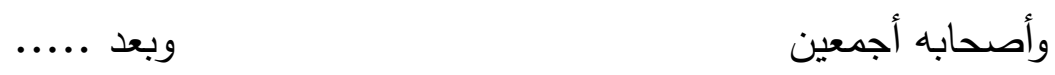

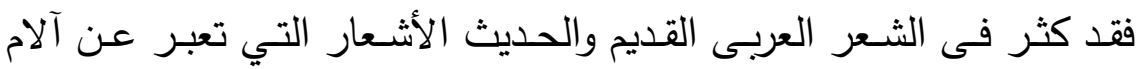

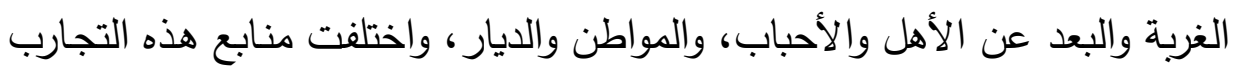

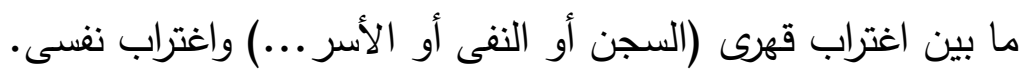

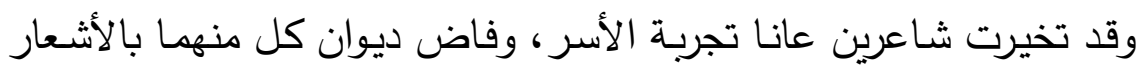

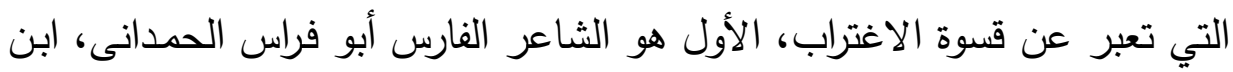
عم سيف الدولـة الحمدانى أمير دولة بنى حمدان في حلب الب والمولى هوصل، والآخر :

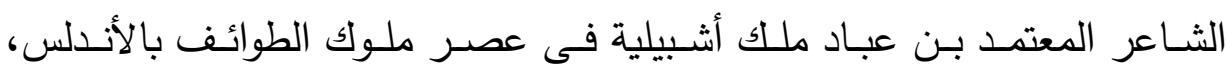

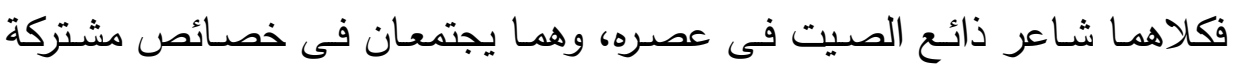

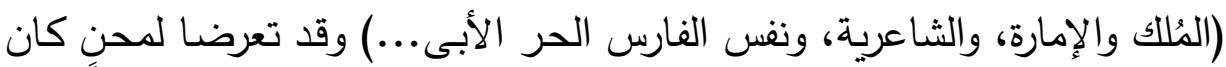

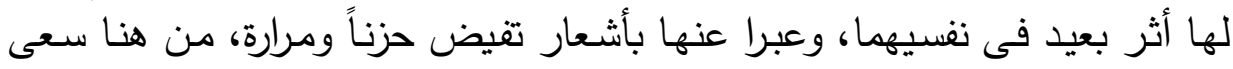

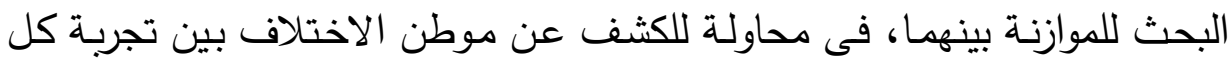

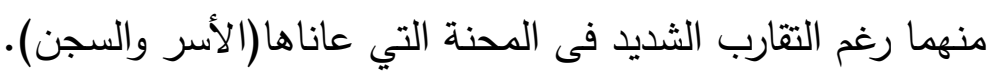

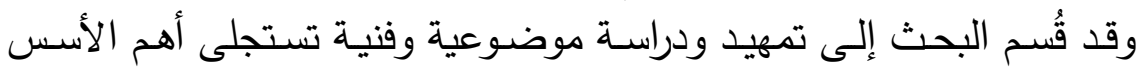
والظواهر والعناصر الموضوعية لشعر الاغتراب عندهما وكان أهم هذه الأسس: الفخر ، والصبر والتحمل، والشكوى، والاستتجاد.

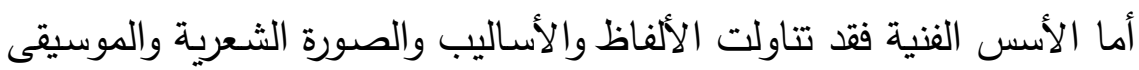

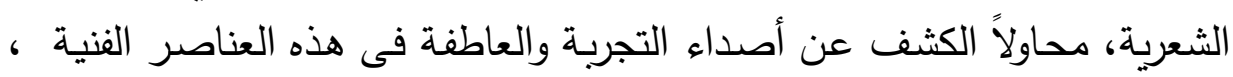

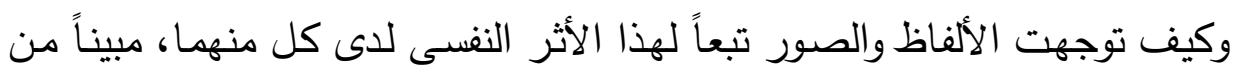
خلال ذلك ملامح الاتفاق والاختلاف بينهما، ومواطن تفوق أحدهما على الآخر . ثم أعقبت ذلك بخاتمة تتضمن أهم نتائج البحث وثبتاً للمراجع.

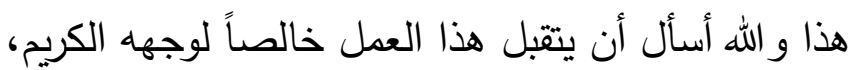

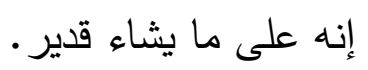


الاغتراب بين أبى فراس والمعتمد بن عباد - دراسة وموازنة

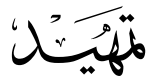

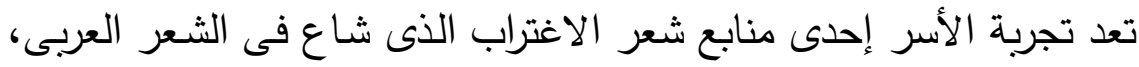

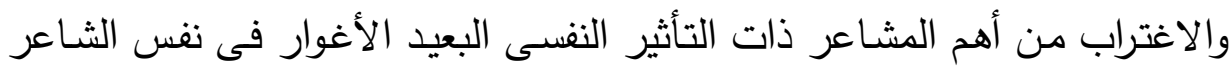
والقارئ على حد سواء ؛وذلك لأنسه ينبع من عاطفة ملتهبة وتجربـة صـادقة فنيا وواقعياً، وهذا هو سر التواصل النفسى الذى ينبع من المعانى الإنسانية.

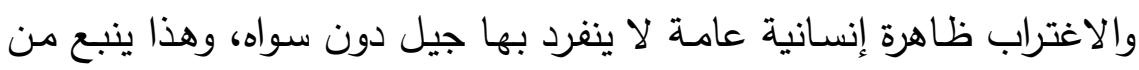

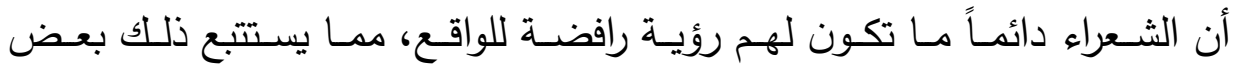

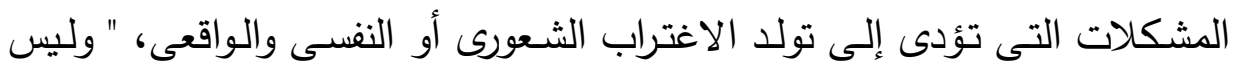

كالاغتراب شىء يزيد من حنين الإنسان إلى وطنه وتعلقه به" (').

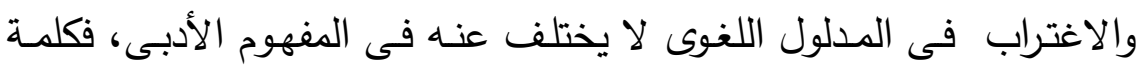

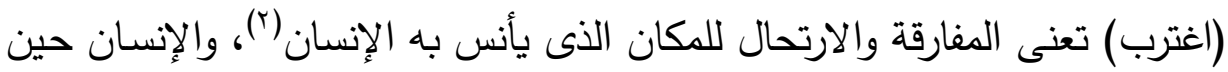
يتعرض للاغتراب تتعرض نفسه لحالة من الانقطاع عن العالم حوله.

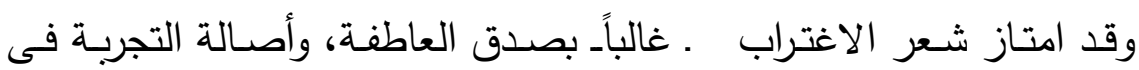

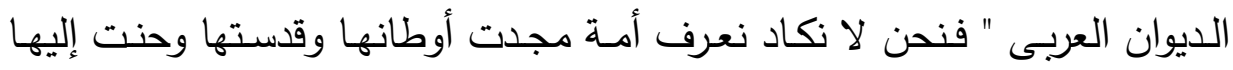

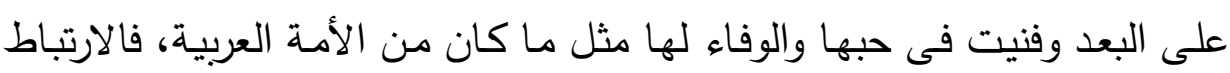
بالأرض عندها هو ارتباط التاريخ والمصير ، وعاطفة الوطنية فى وجدانها عاطفة وله

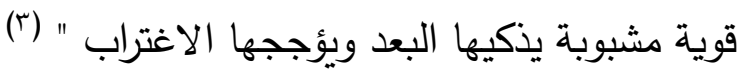

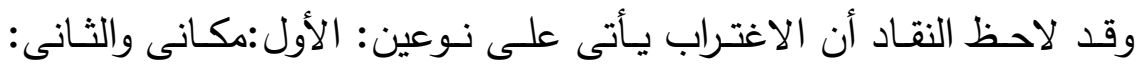

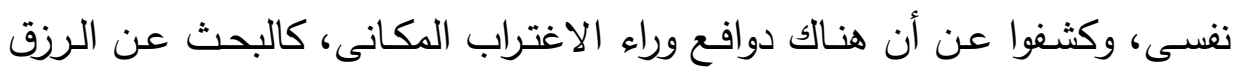
مثلما يفد الشعراء إلى الملوك لطلب العطايا كما هو الحال عند أبى تمام والبحترى

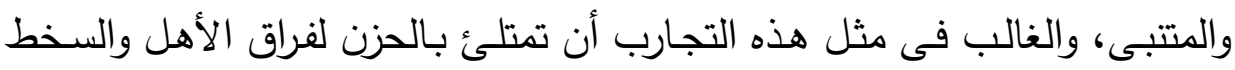
على الدهر الذى دفعه لمفارقة أهله، فها هو المتنبى يقول:

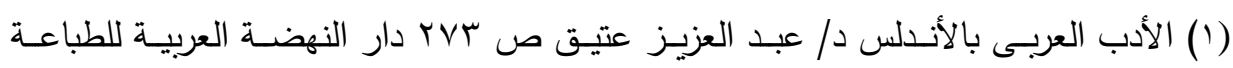
والنشر

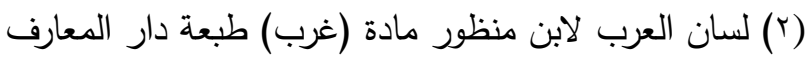

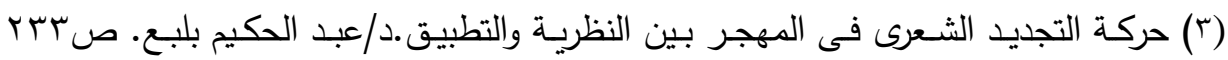

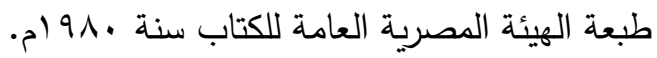


الاغتراب بين أبى فراس والمعتمد بن عباد - دراسة وموازنة

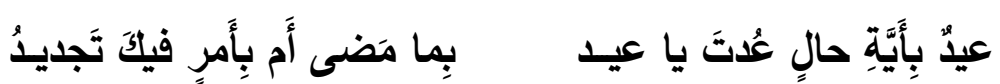

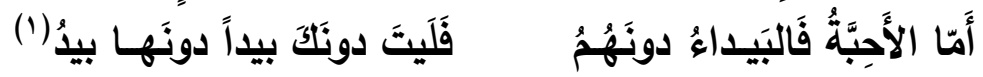

$$
\text { وها هو ابن الرومى يقول: }
$$

وألا أرى غيري لله الاهرَ مالكا(؟)

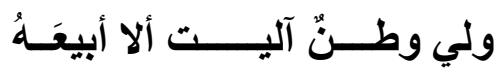

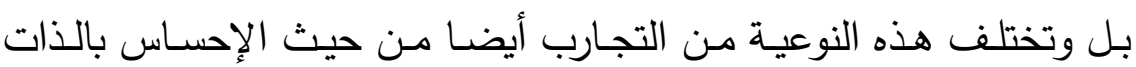

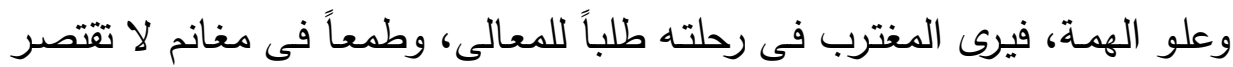

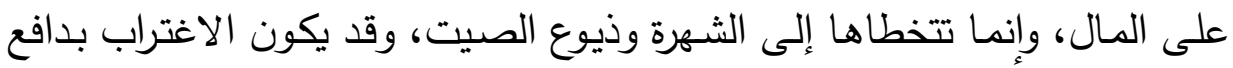
التعلم، وهنا تسمو الغايـة بالتجربـة فتدفعها لأن تكون ذات بُعد جليل القدر التهات عظيم

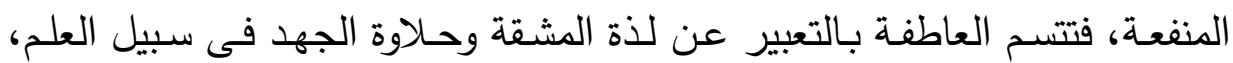

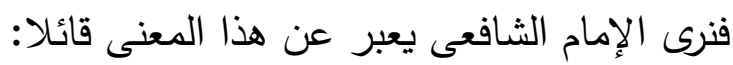

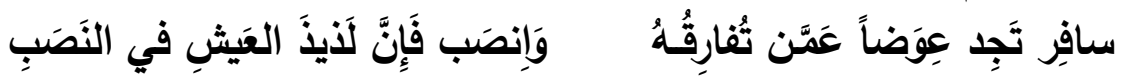

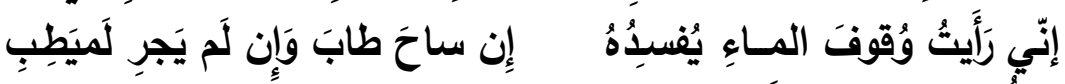

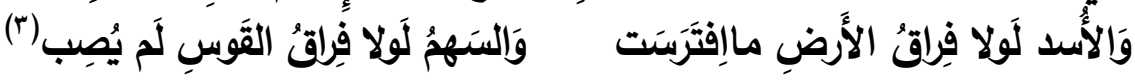

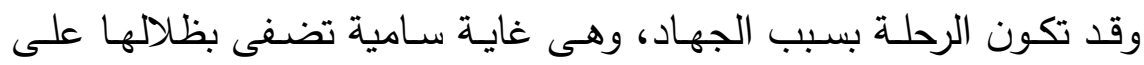
عاطفة الثـاعر، فالحنين إلى الوطن فيها يكون تشوقا إلى ذكريات سعيدة ومرابع

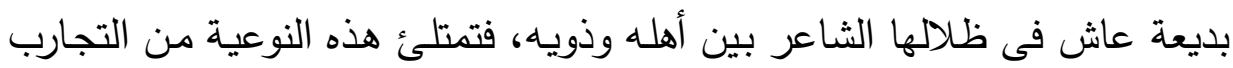

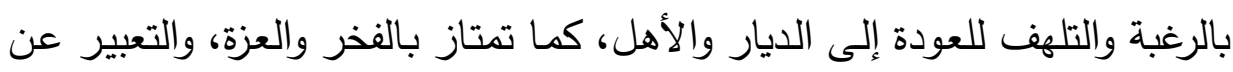

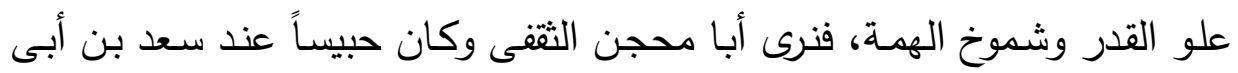

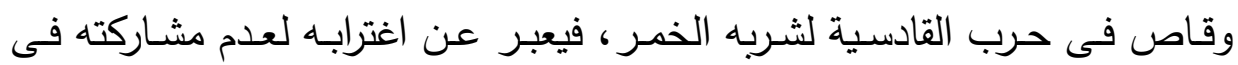

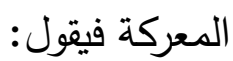

وأُصبِحَ مَثدوداً علـيَّ وَثَّاقِيا

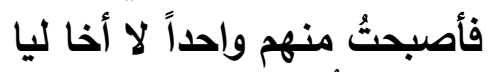

وتذهلُ عني أُسرتي ورجاليا (؛) واهُ
كفى حَزَناً أن تُطعَنَ الخيلُ بالقَنَا

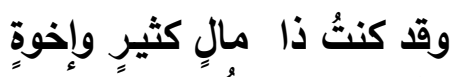

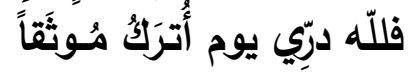

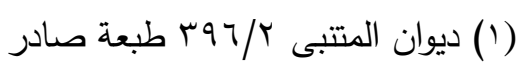

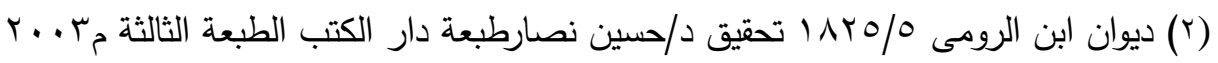

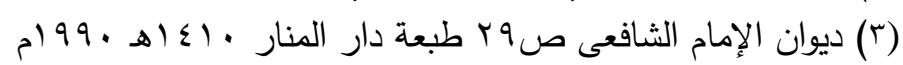

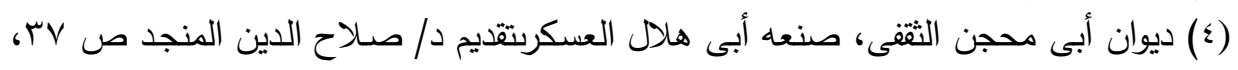

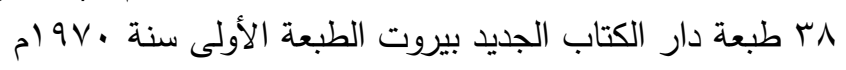


الاغتراب بين أبى فراس والمعتمد بن عباد - دراسة وموازنة

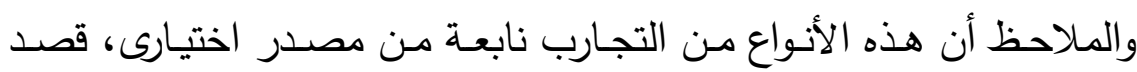

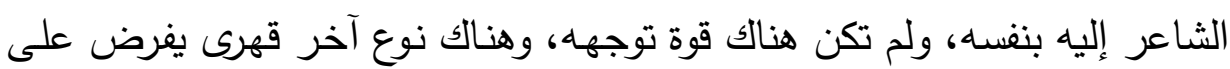

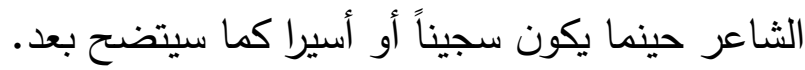

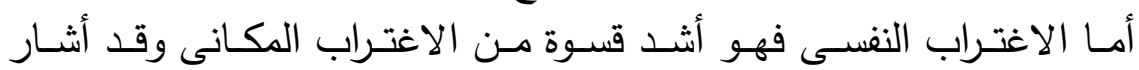

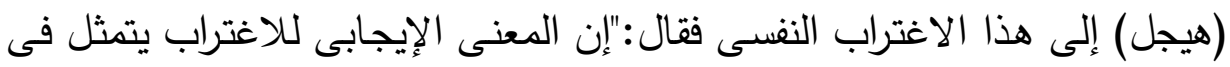

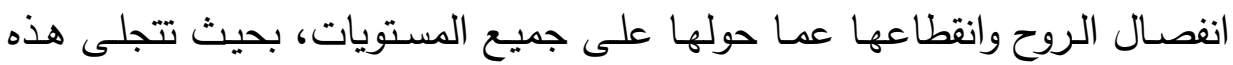

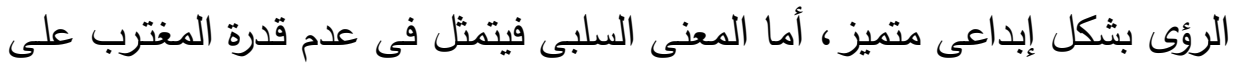

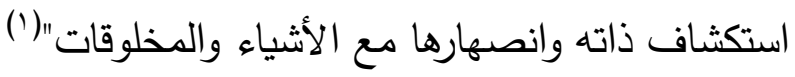

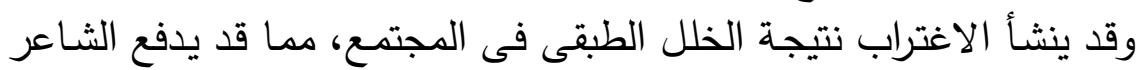

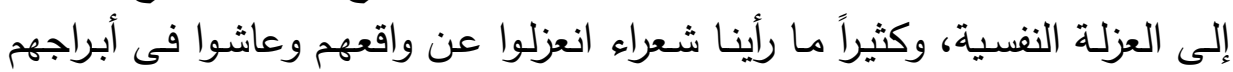

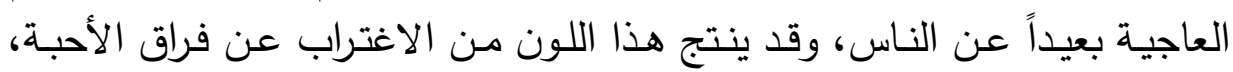

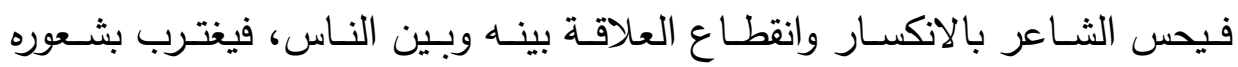
ووجدانه عن الناس، فها هو مجنون ليلى يعانى آلام الهجر فيقول:

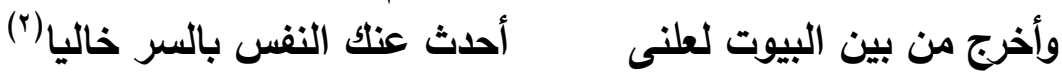

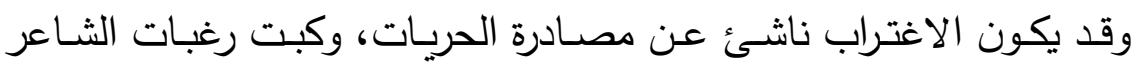
فياتى شعره زفرة حارقة فى سماء هذه الحياة الخانقة.

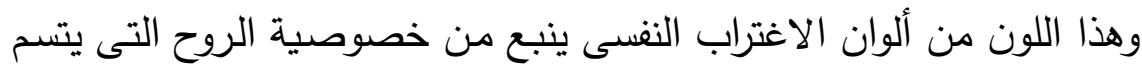

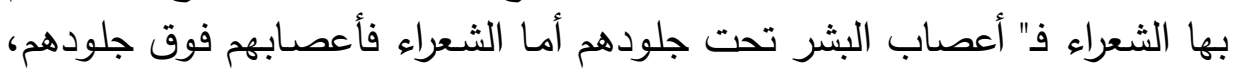

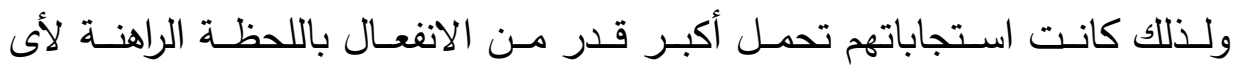

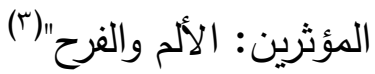

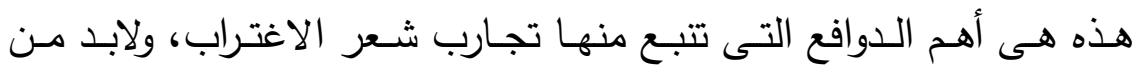

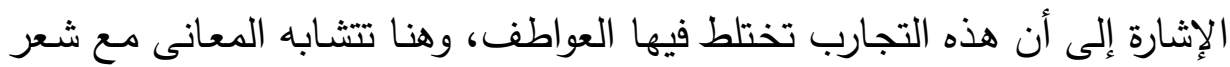

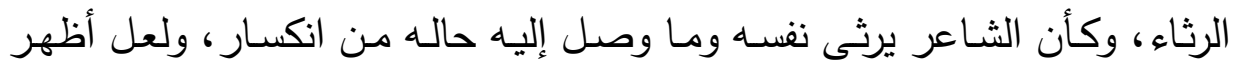

( ) الاغتراب سـيرة ومصـطلح. محمـود رجب. ص |ل طبعـة دار المعـارف سـنة 919 ام بتصرف.

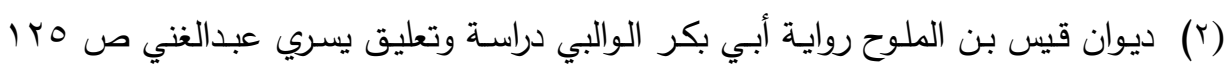

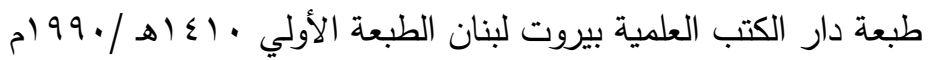

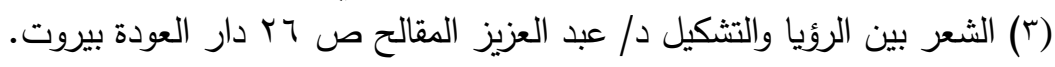


الاغتراب بين أبى فراس والمعتمد بن عباد - دراسة وموازنة

صورة لهذا مراثى الشعراء لأنفسهم فهذه المراثى صسورة من شـعر الاغتراب وإن بدت رثاءًً.

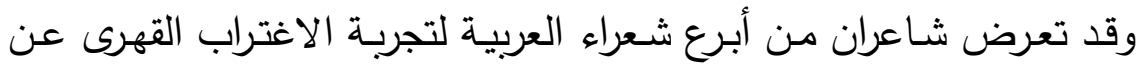

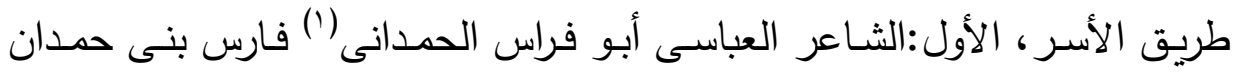
وشاعرهم المقدم وابن عم وصهر الملك سيف الدولة الحمدانى صاحب الدئ المتبى.

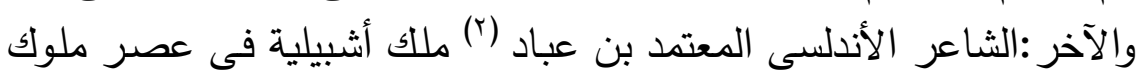

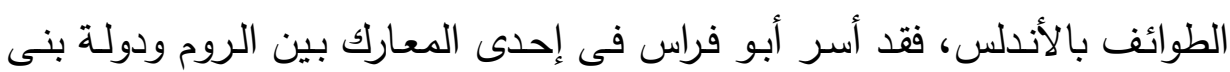

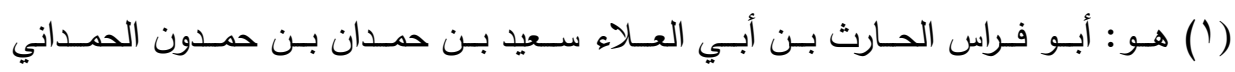

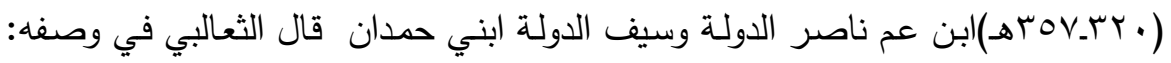

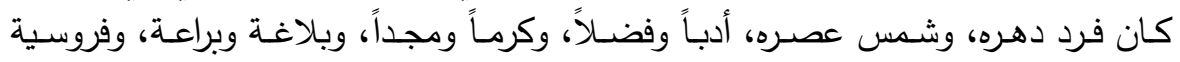

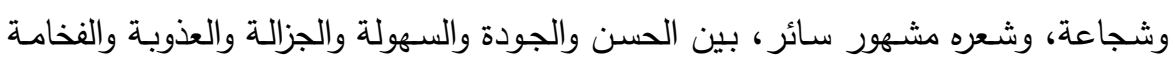

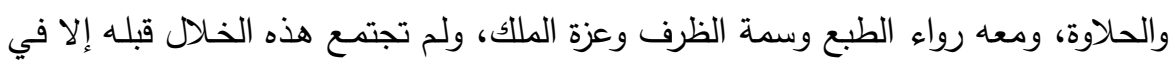

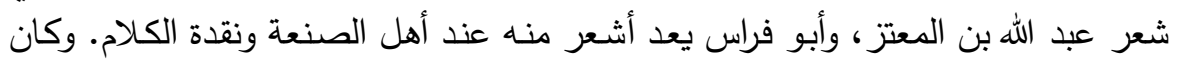

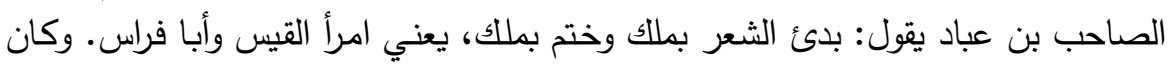

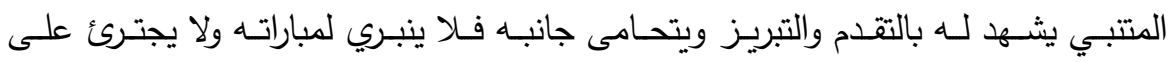

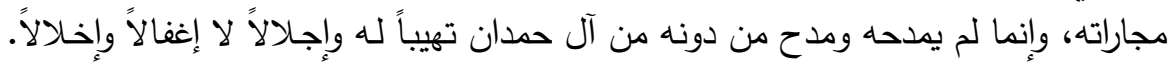

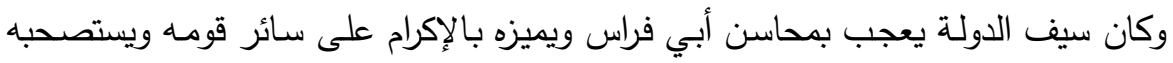

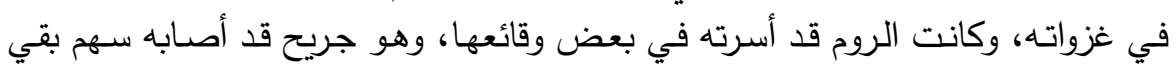

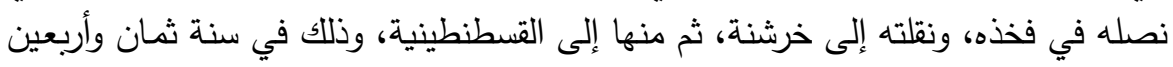

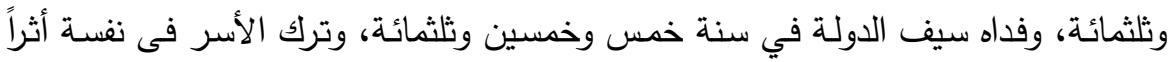

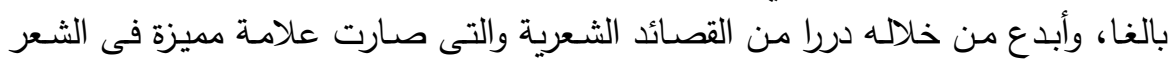

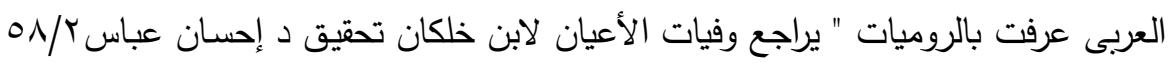

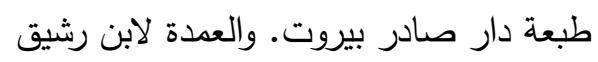

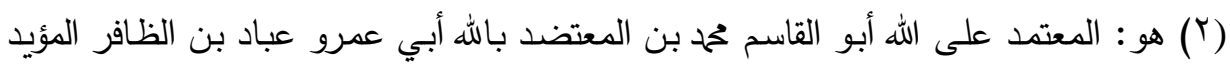

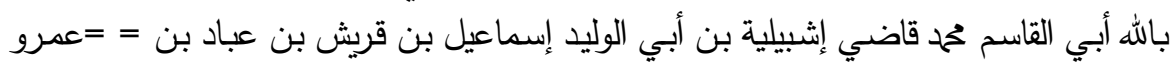

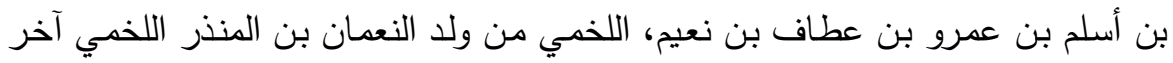

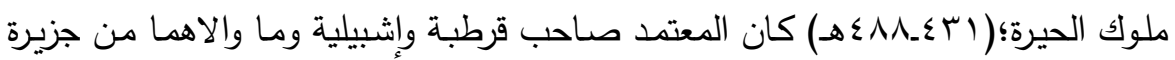

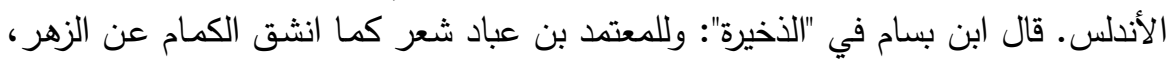

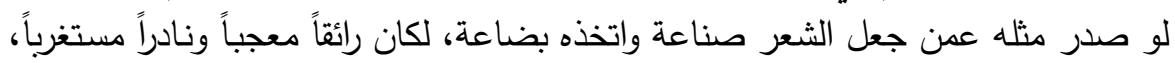

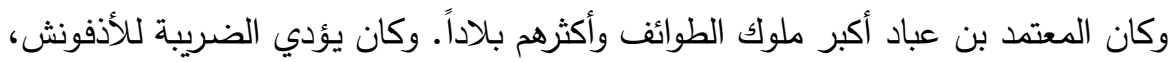

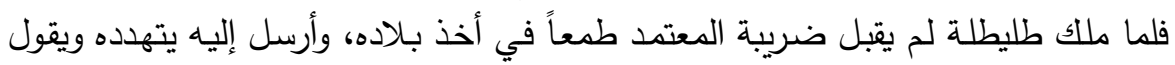




\section{الاغتراب بين أبى فراس والمعتمد بن عباد - دراسة وموازنة}

حمدان ممن كانوا يقومون على حدود الدولة الإسـلامية ضد الروم، وظل يعانى

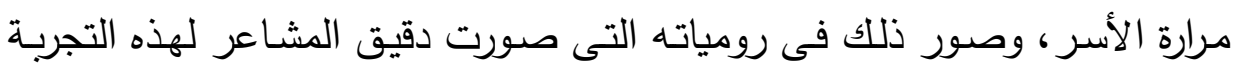

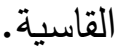

أما الآخر :فقد عاش مفارقات الزمن، وتضادات الواقع بين حياة المُلك الرغيد

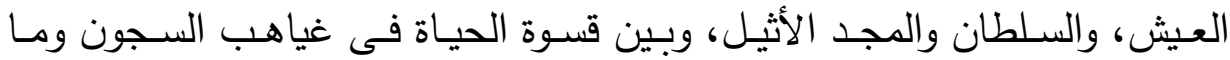

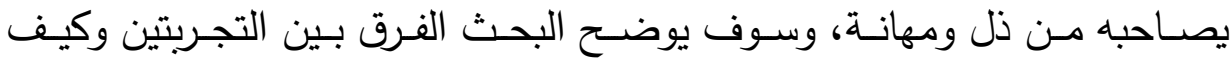
عالجاها حسب تصورهما كملكين من ملوك العرب.

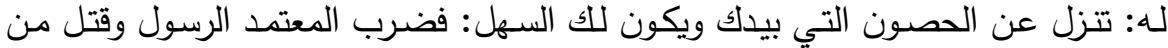
كان معه، فبلغ الخبر للأذفونش وهو متوجه لحصار قرطبة فرجع إلى طليطلة لأخذ آلات

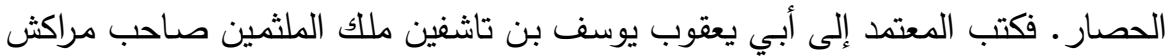
يستجده، فلما وصله خرج مسرعاً لقتالهم وانتصر المسلمون وهرب الأذفونش بعد استئصال

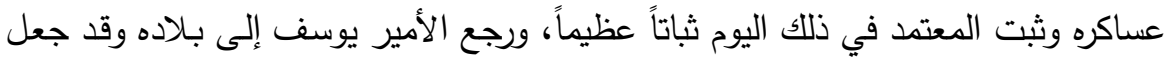

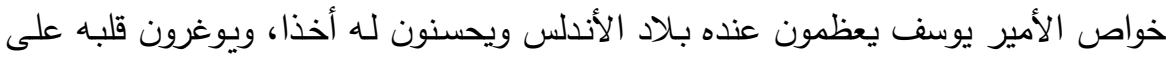

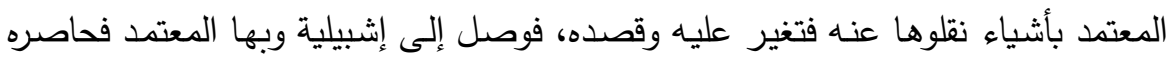

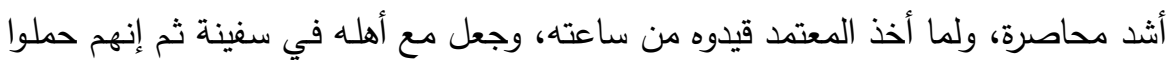

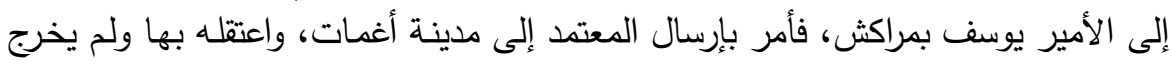

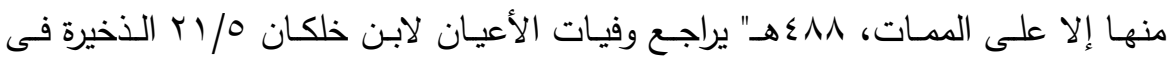

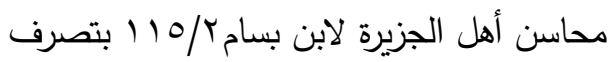


الاغتراب بين أبى فراس والمعتمد بن عباد - دراسة وموازنة

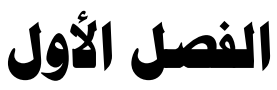

\section{الاغتراب بين أبى نراس والمعتمد رؤية هوضوعية}

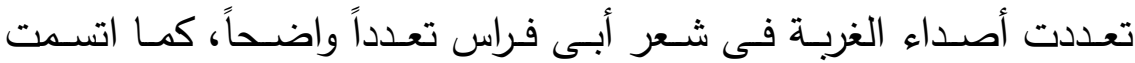

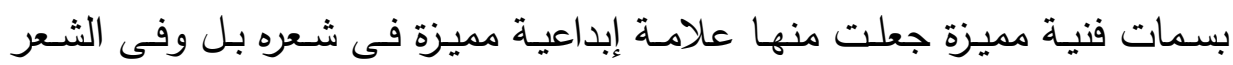
العباسـى والعربى بأكمله، حتى سميت بالروميات، ففى هذه التسمية تتجلى لنـا

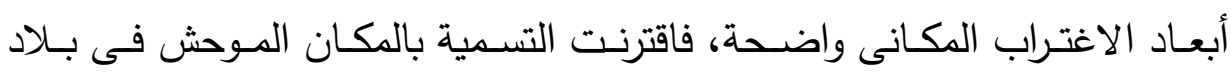

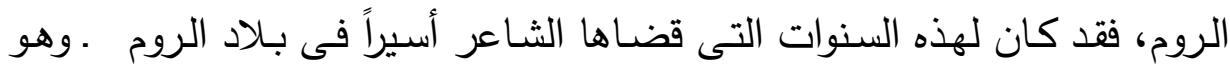

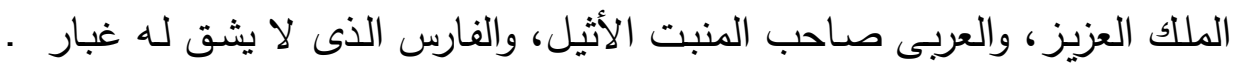

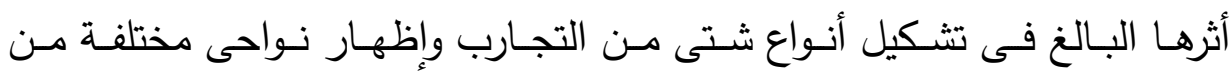

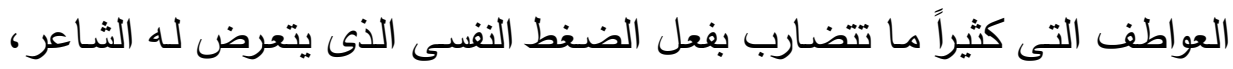

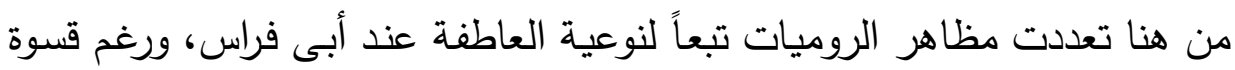

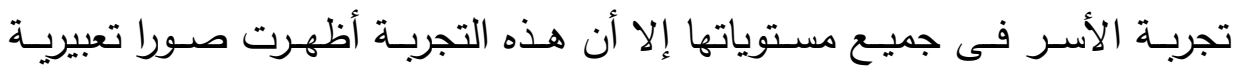

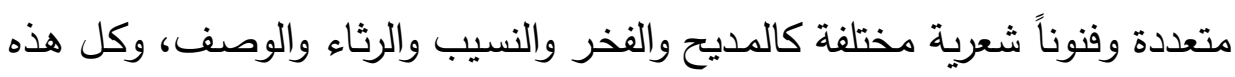
الأغراض اصطبغت بروح التجربة القاسية التى يعانيها، فأعطت هذه الروح لهذه وله الفنون صبغة خاصة عما كان مألوفا فى الشعر العربى. أما المعتمد فقد كانت تجربته قاسية مؤلمة لا تتعلق بنفسه الأسيرة ولا ملكه فئه

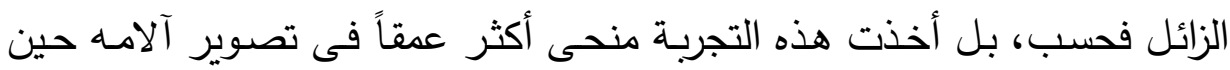

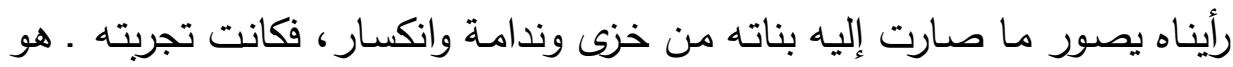

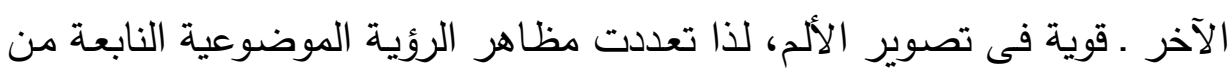

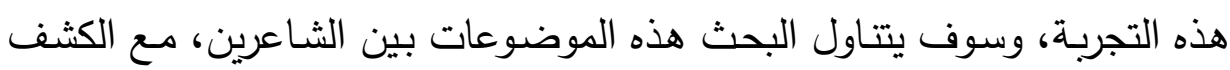

\section{أولاً:الفخر} عن مواطن الاتفاق والاختلاف بينهما.

\section{أ. عند أبى فراس}

يختلف الأثر الناشئ عن تجربة الأسر فى نفس كل إنسان حسب طبيعته النفسية والاجتماعية، ونحن الآن أمسام ملك عرف بأصله الثربفة الأفر ومنبته الرفيع

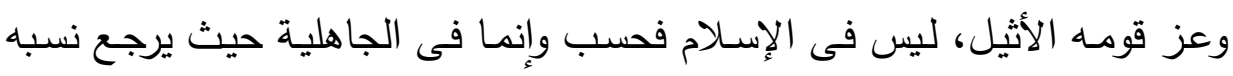


الاغتراب بين أبى فراس والمعتمد بن عباد - دراسة وموازنة

إلى قبيلة تغلب وهم الذين قيل فيهم:" كانت بنو تغلب ابن وائل من أشد الناس في

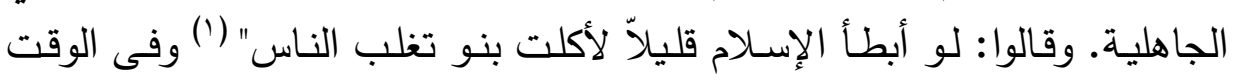

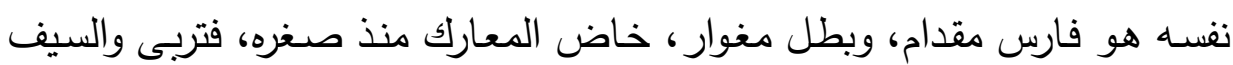

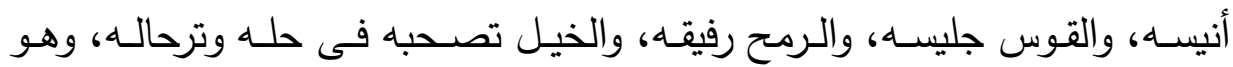

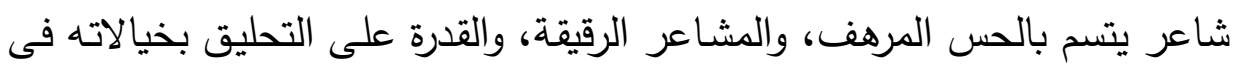

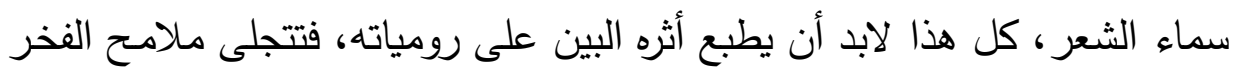

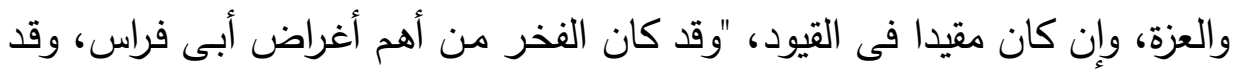

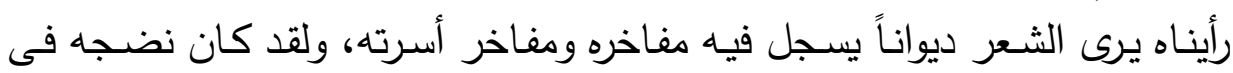
هذا اللون من القول مبكراً مما يدل على شعوره بمكانة أسرته ومكانته" (؟)، فنراه

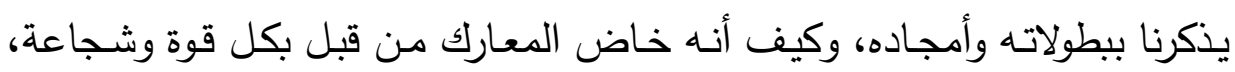
فيقول:

مَقامي يَومَ ذَلَلَكَ أَو مَقـالي

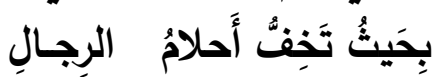

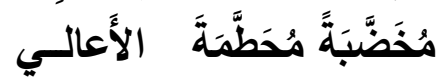

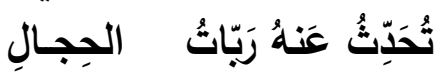

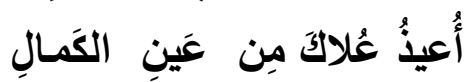

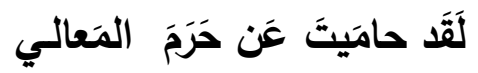

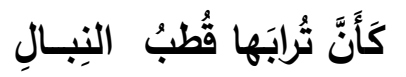
فَفَي بَعضٍ غَلى بَّضٍ تُعَالي

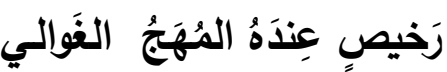

وَإِن مُتنا فَمَوتاتُ الرِجِالِ

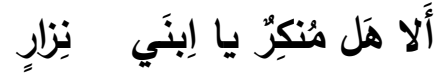

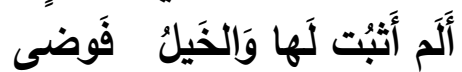

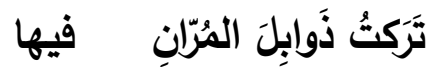

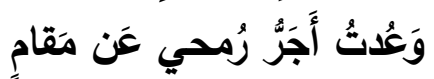

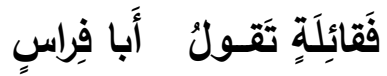

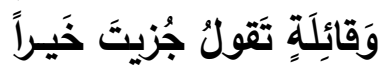
وَمُهري لايَمَسُّ الأَرَضَ زَهَهواً

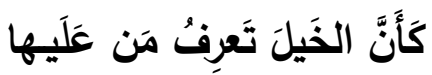

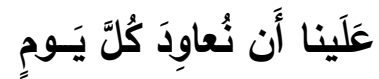

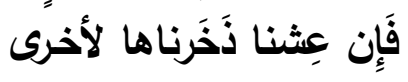

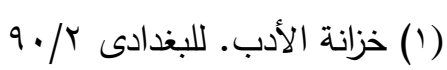

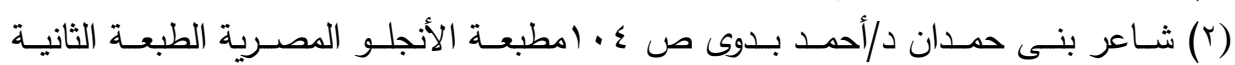
سنة 90 أم

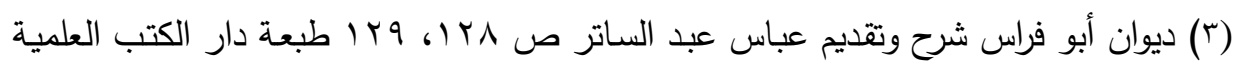

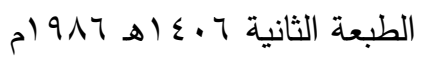


الاغتراب بين أبى فراس والمعتمد بن عباد - دراسة وموازنة

إنه يذكرنا بيوم من أيام بنى حمدان على الروم، وكانوا قد أغاروا على

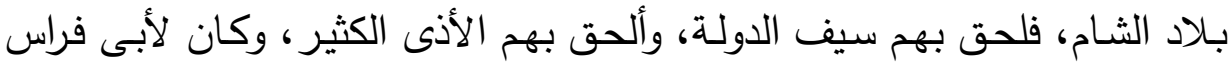

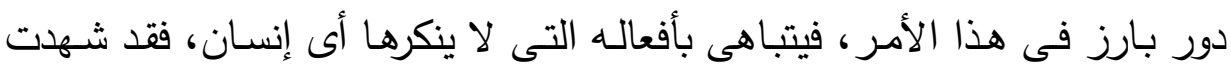

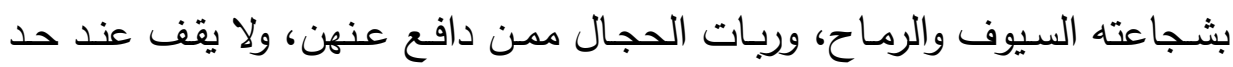
وصف نفسه بالقوة، وإنما نرى صورة مصاحبة لهذا المعنى حين نرى الخيل تزهو ولئ

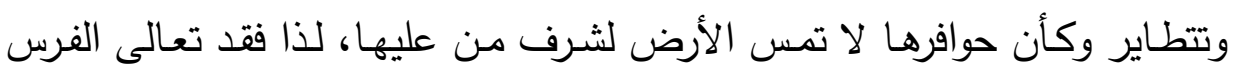
على بنى جنسـه لعلمه بقدر فارسـه، ثم يعبر عن شجاعته وصـموده، فهو ينتظر الموت فى هذه المعركة، فإن لم ياته اليوم فسيأتيه فى المعركة القادمة.

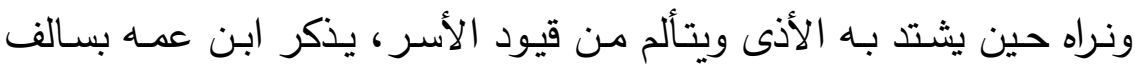
عهده وبطولاته التى تستحق أن يسعى سيف الدولة لافتدائه، فيقول:

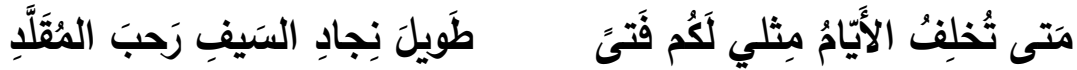

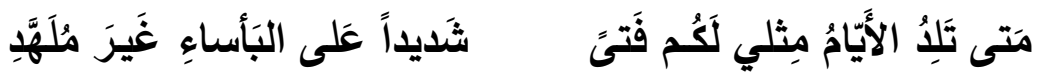

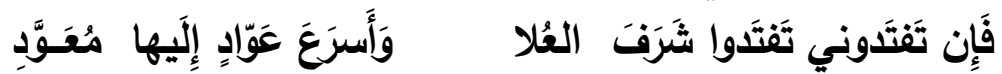

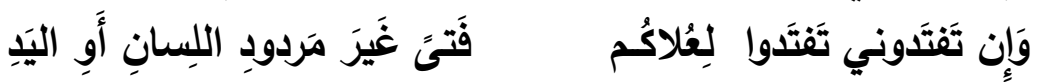

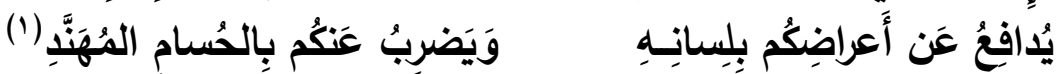

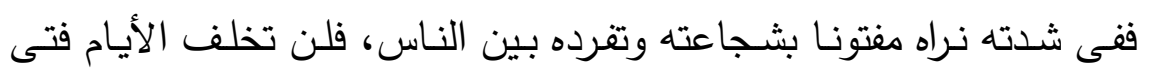
مثله يدافع عن قومه بيده ولسانه.

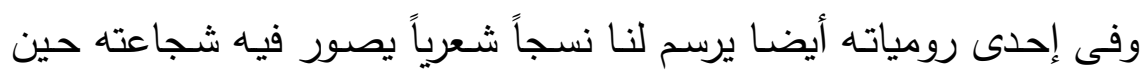

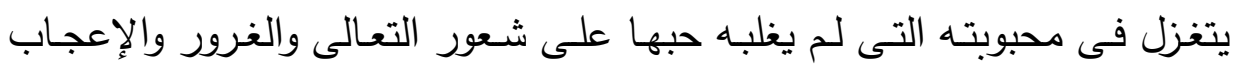

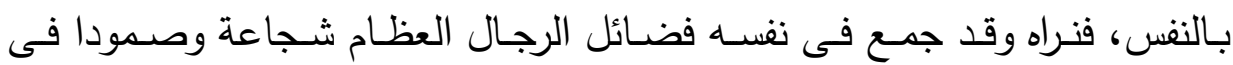
المعارك، فلا ينزل على أعدائه دون أن يسبقه إنذار لهم، مما يدل على فئل قوته وثقته

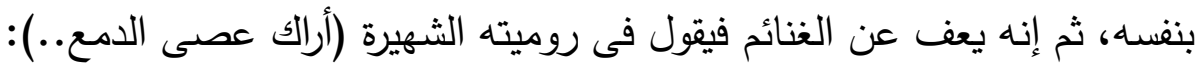

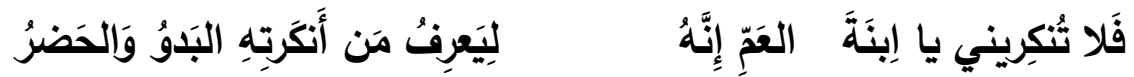

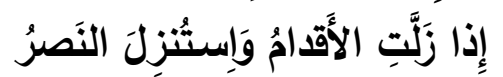

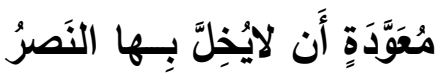

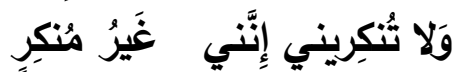

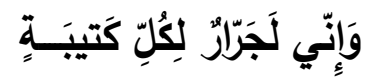
(1) (1) ديوان أبو فراس ص 0 0)، 
الاغتراب بين أبى فراس والمعتمد بن عباد - دراسة وموازنة -

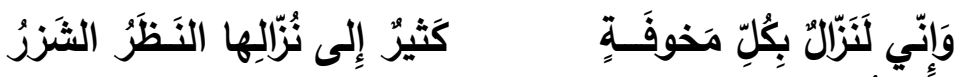

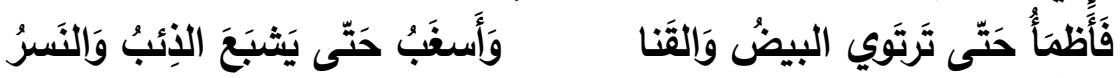

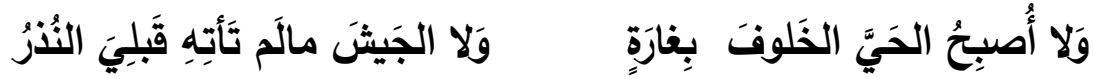

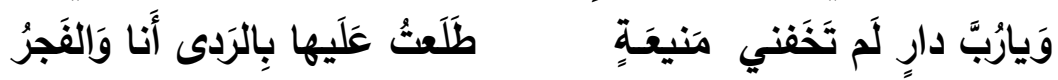

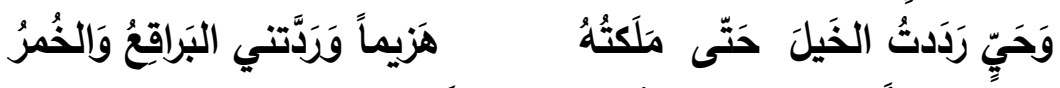

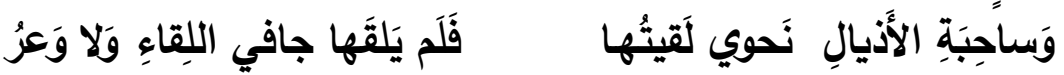

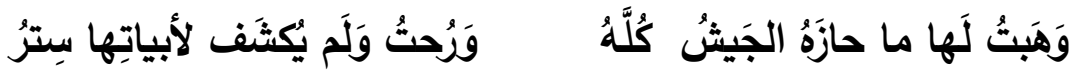

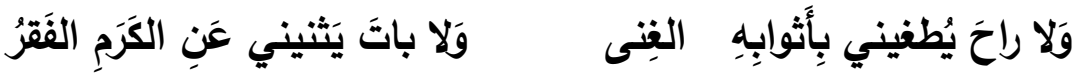

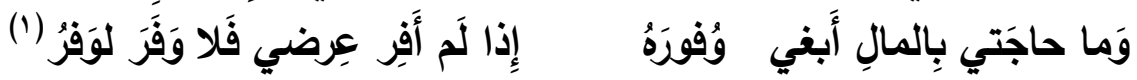

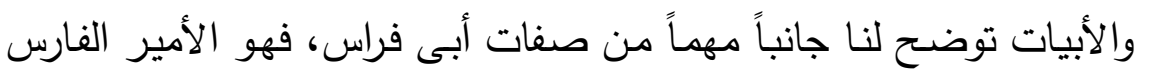

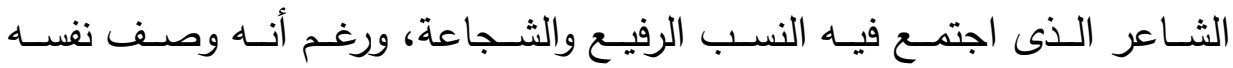
بالشجاعة على عادة السابقين فلا يختلف عنهم كثيراً فى عباراته حين يقول:

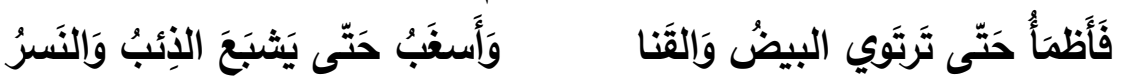
وهو من قول عنترة:

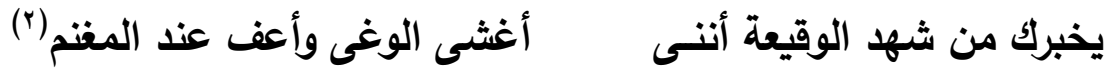

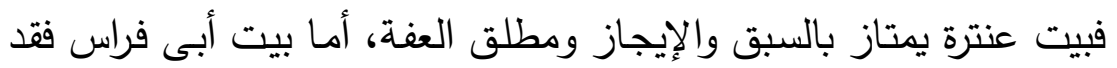

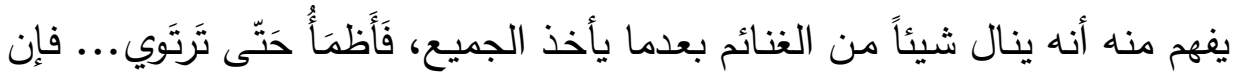

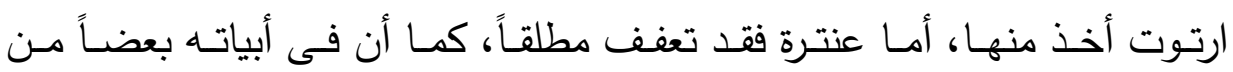
التناقض فيقول:

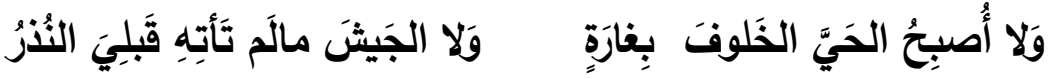

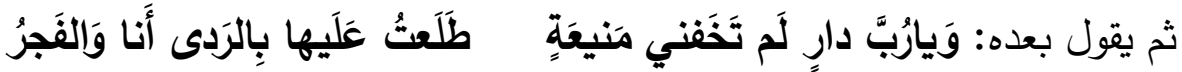

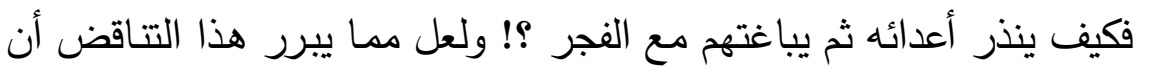

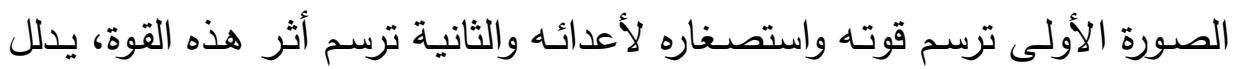

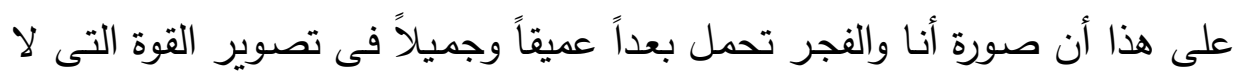

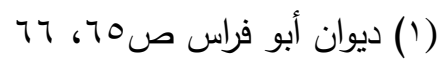

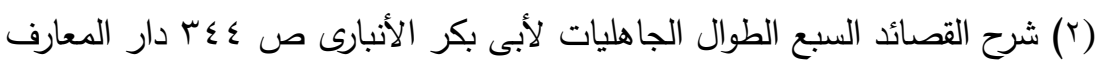


الاغتراب بين أبى فراس والمعتمد بن عباد - دراسة وموازنة

تقهر ، وأنه قد غدا لهم نوراً بعدما عاشوا فى ظلماتهم التى هى أشبه بظلمات الليل

ورغم أنه فى أسره يعانى ذل الحبس وقسوة الحرمان، إلا أنه دائم الذكر لعز

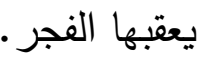

قومه، والفخر بهم وبمجدهم الباذخ ونسبهم العريق، يقول:

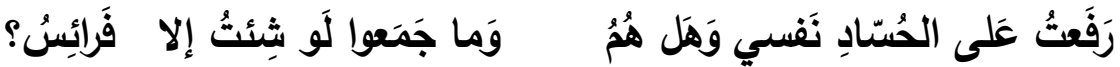

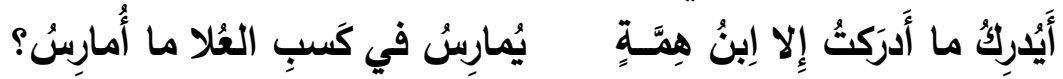

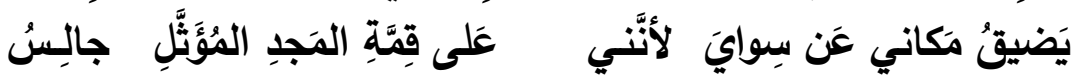

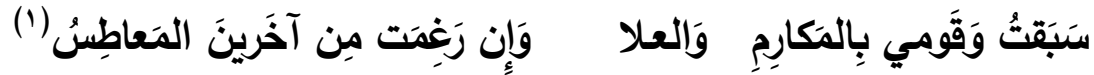

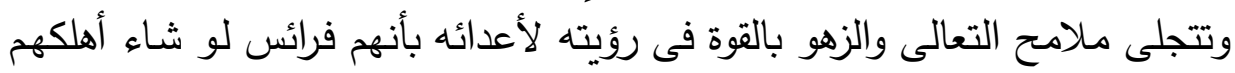

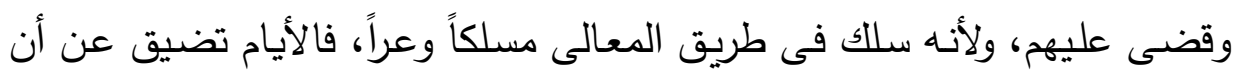

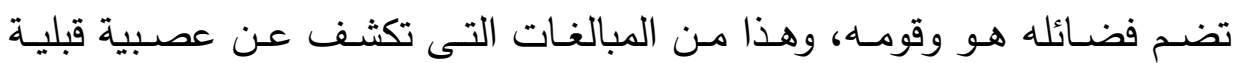
جاهلية، لذا فهو يرى أن سلطان بنى حمدان إرثاً يتوارثه الأبناء، يقول:

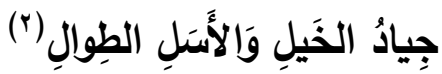

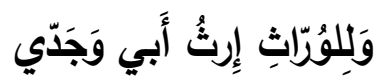

وإحساس الشاعر بالتقرد يملأ فكره ويشخل كل أحاديثه، فيقول:

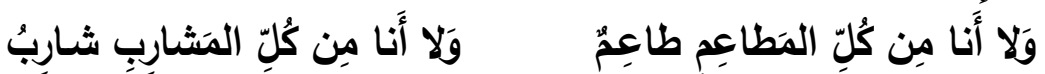

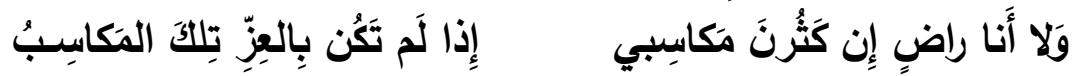

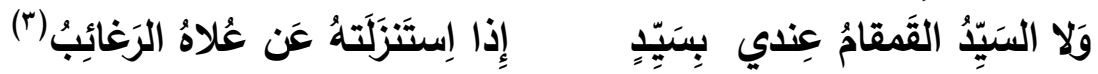

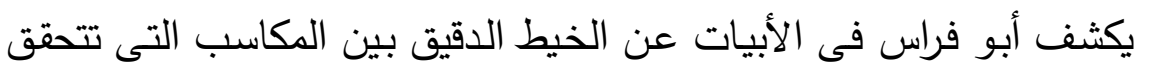
عن طريق السلب والنهب مما يفعله قطاع الطريق وصـعاليك البادية، ومـا يفعله السادة من بناء الحضارات والملك، فشتان بينها وبين أفعال السفلة.

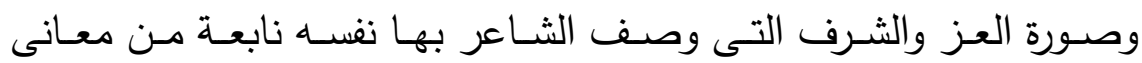

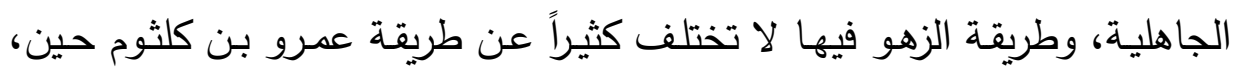
يقول:

$$
\begin{aligned}
& \text { (1) ديوان أبو فراس صـ1 ـ }
\end{aligned}
$$

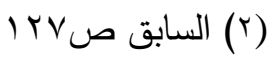

$$
\begin{aligned}
& \text { ro r) السابق ص r) }
\end{aligned}
$$


الاغتراب بين أبى فراس والمعتمد بن عباد - دراسة وموازنة

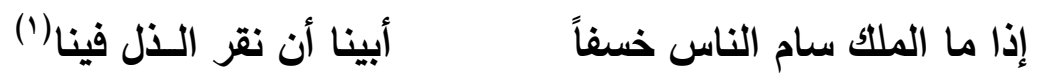
وتتبدى لنا ملامح فخر الثاعر بنفسه حين يجمع الصفات التى تجعله أعلى التى قدماً وأرقى نسبا من هؤلاء السفلة من الروم الذين أسروه، فيقول:

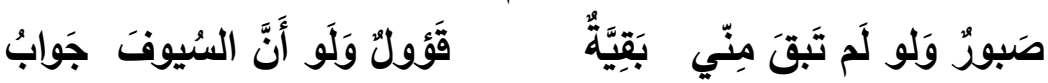

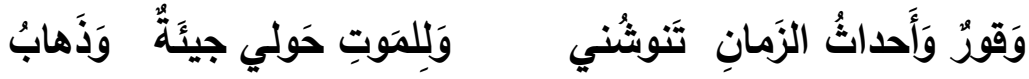

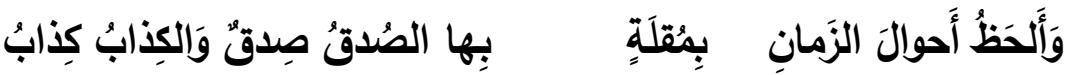

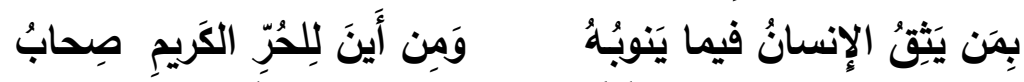

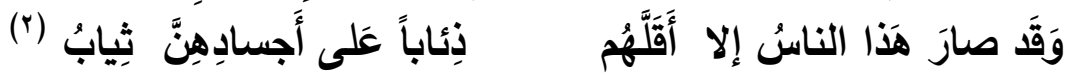

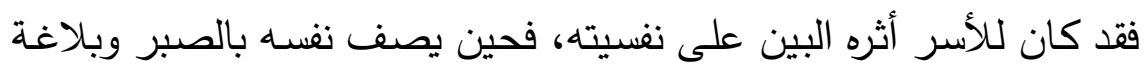

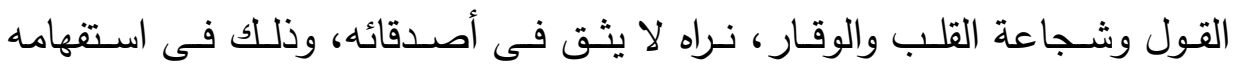

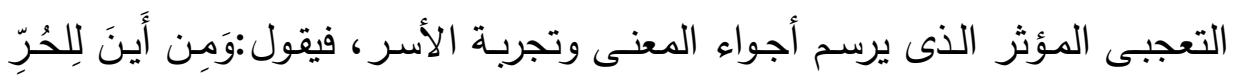

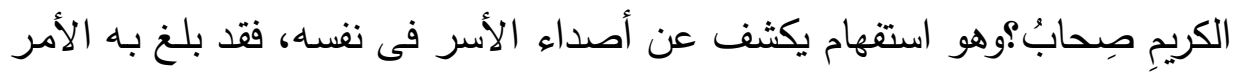
إلى الدرجة التى رأى من أسروه كلاباً، والعجب أنها تتحكم فى الأسود. يقصد نفسـ التهـ

وروافد الفخر عند أبسى فراس ليست روافد شخصية بقدر مـا هـى روافد

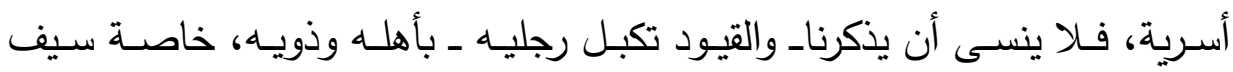
الدولة، وهو استعطاف مستتر لا تقوى عليه إلا عاطفة ملك تفيض حتى منتهاها

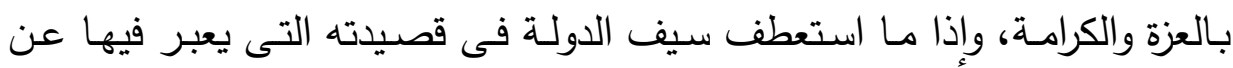

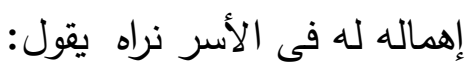

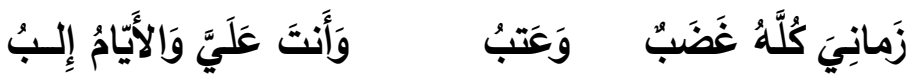

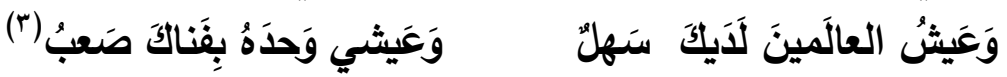
فهو يستعطف ابن عمـه بأسلوب يغلب عليه التعالى والترفح، ثم يتلو هذا بأبياته التى تتسم بالفخر ، فلا تتفصل فيه ذاته عن ذات سيف الدولة، فيقول:

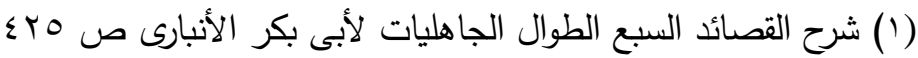

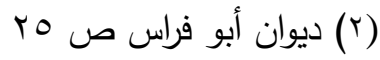

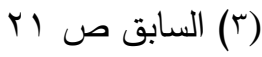


الاغتراب بين أبى فراس والمعتمد بن عباد - دراسة وموازنة

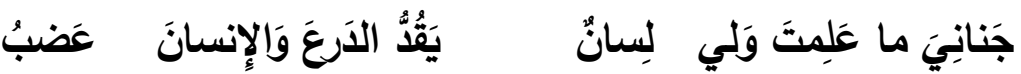

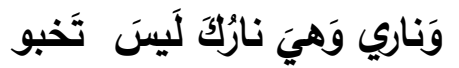

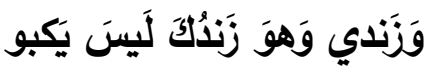

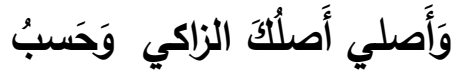

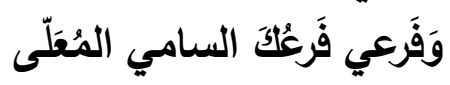

وَفَي إِسحَقَ بي وَبَنيِِ

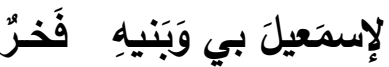

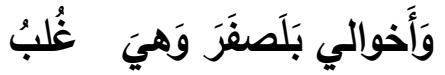

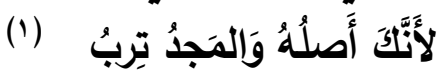

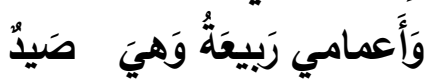

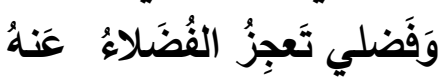

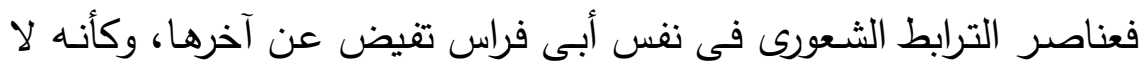

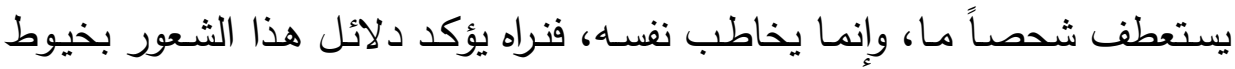
نسيج شـعرى مشرق بالفخر فى موقف الاستعطاف حين يقول: "زندى زندكلك...

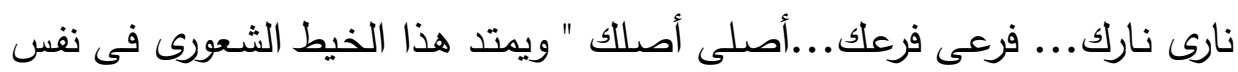
أبى فراس حين يزهو بنفسه وبنسبه الرفيع هو وسيف الدولة.

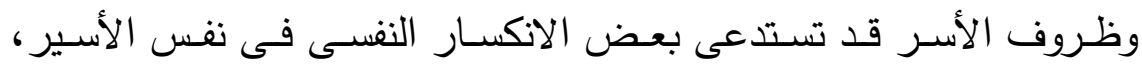

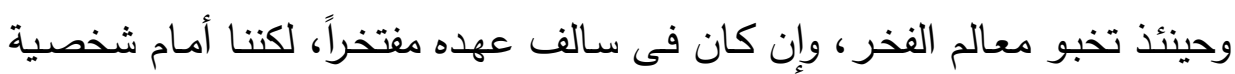
صامدة جديرة بأن تتحدى المصاعب، ولا يخطر ببال أحد أنها تستسلم حتى ولو

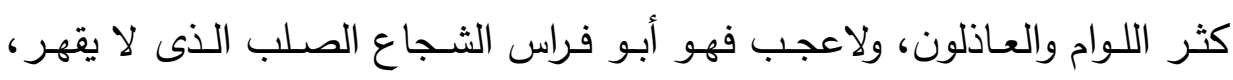
يقول:

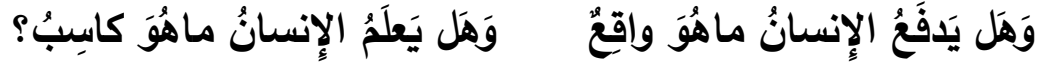

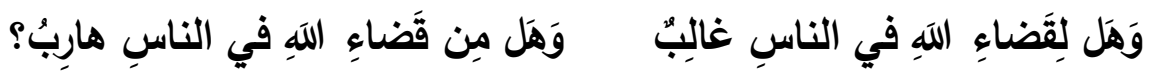

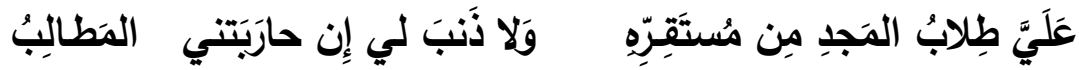

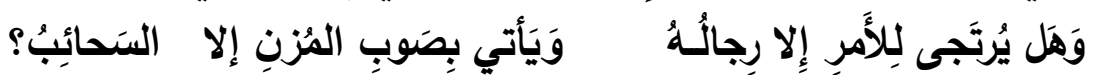

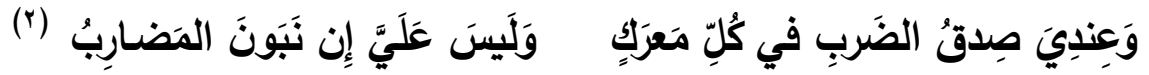

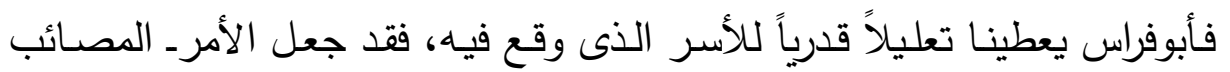

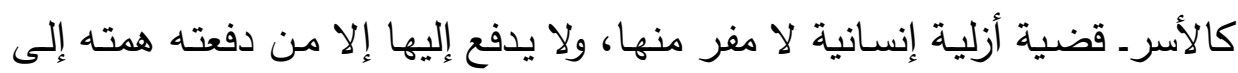

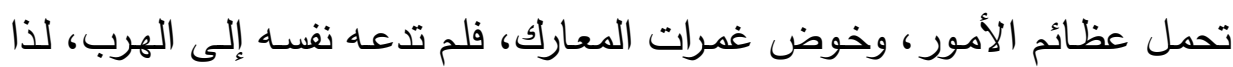

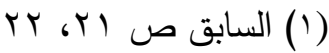

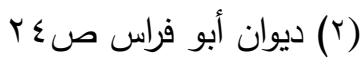


الاغتراب بين أبى فراس والمعتمد بن عباد - دراسة وموازنة

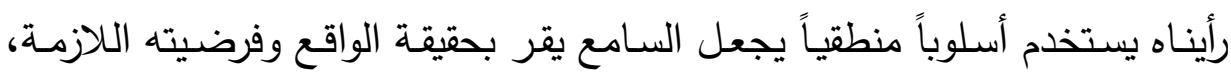

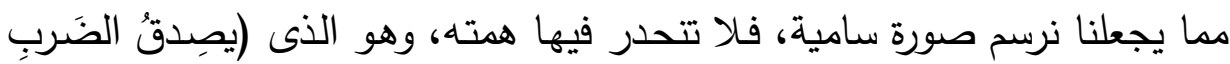

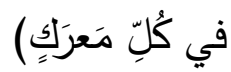

وتتعدد مظاهر الفخر عند أبى فراس رغم شدة البلوى وقسوة الألم وامتداد

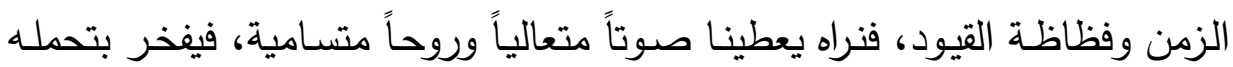
وصبره الذى يكثف عن همة فارس شجاع، يقول:

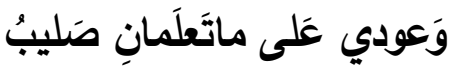

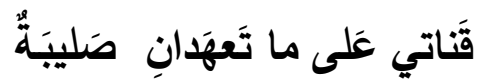

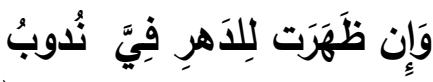

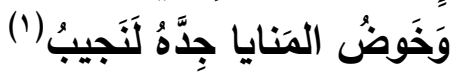

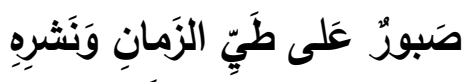

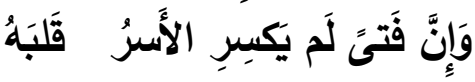
فنراه يقدم لنا مؤثرات تصـويرية رمزيـة تكشف عنف عن شعوره، فقناته (صليبة) مصلوبة، وجسده شد بالأغلال وكأنه فى وضع المصلوب، وجمعه بينه وبين التناة

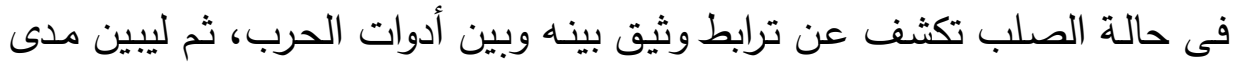

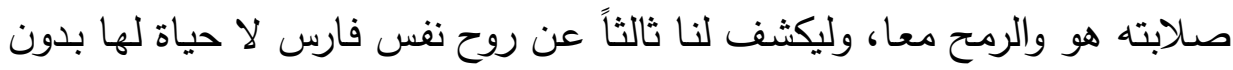
قتال، ولأن الصبر على هذا القيد قد ينبع مـن روافد متعددة فقد يكون انكسـاراً

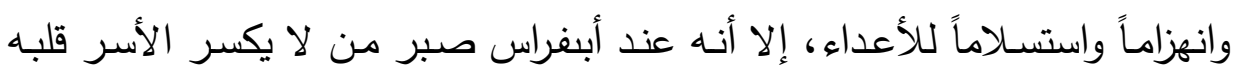
لذا فهو حقاً (نجيب)، هكذا يرى أبو فراس الصبر فخراً، والتحمل فضيلة، ونراه يؤكد هذا المعنى فى قصيدة أخرى، فيقول:

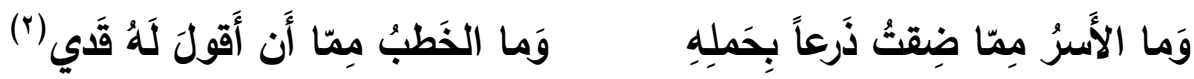

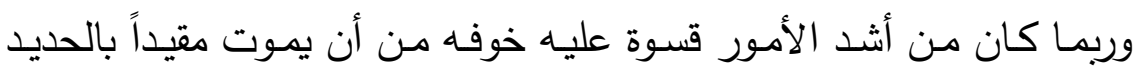
بأيدى أعدائه، فقد كان يرجو أن يموت على النى صهوات الجياد، يقول: عَلى صَهَواتِ الخَيلِِ غَيَرِ مُوَسََّّدِ بِأَيدي النَصارى مَوتَ أَكَمُدَ أَكَبَّ وَلَكَنَّنَي أَختارُ مَوتَّ بَنَي أَبَي

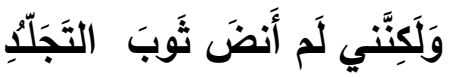

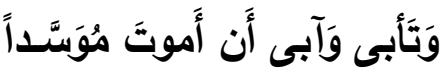

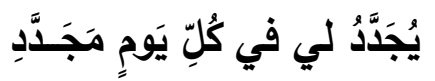

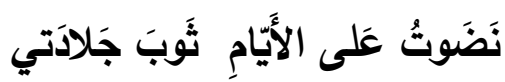

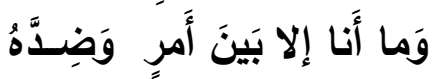

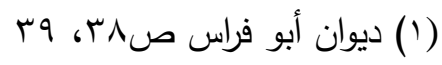

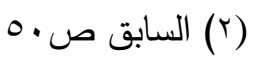


الاغتراب بين أبى فراس والمعتمد بن عباد - دراسة وموازنة

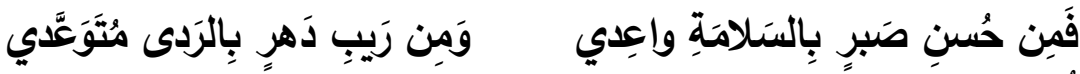

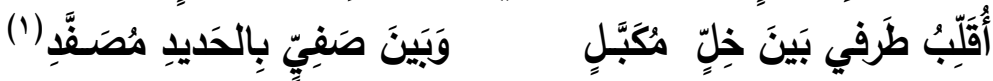

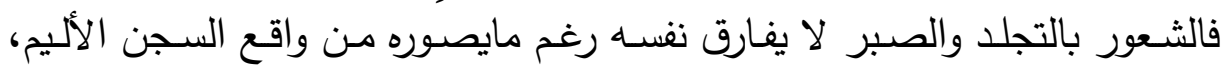

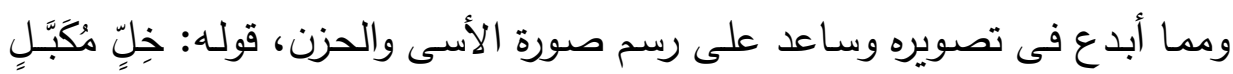

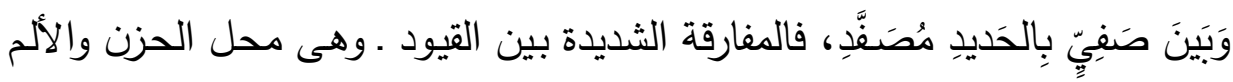

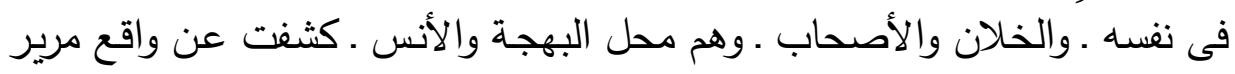
يعيشة الثاعر فى أسره.

ولعل مـن أهم ملامـح فخره تعاليه على أعدائه، وهذا ممـا يضـيف بعداً جديداً لمفهوم الفخر الذى تفيض به نفس أبى فراس، فالأعداء من الروم هم أعداؤه

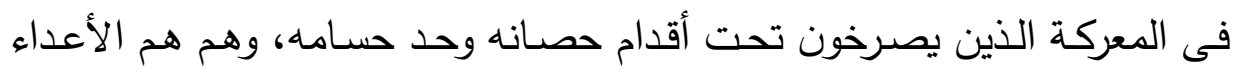
بذلهم وحقارتهم رغم مـا يظنون من قوتهم اليوم، ومن تكبيلهم لـه بالقيود، فيقول مصوراً قوته وعلو شأنه فى مقابل تفاهتهم وضعفهر:

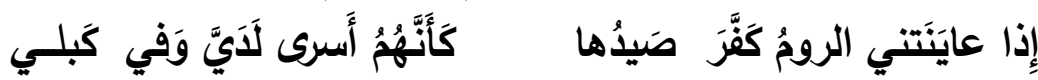

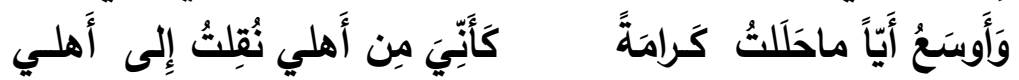

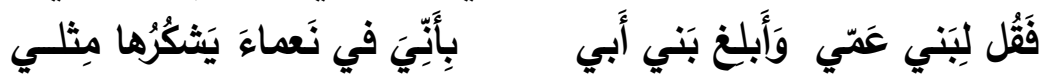

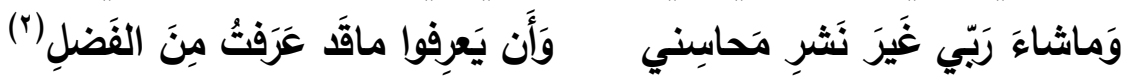
فلنظظر كيف كانت نفسه عالية الهمة شامخة الإحساس إلى الحد الذئى يرى

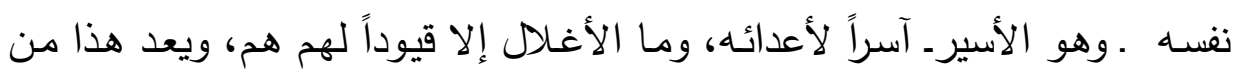

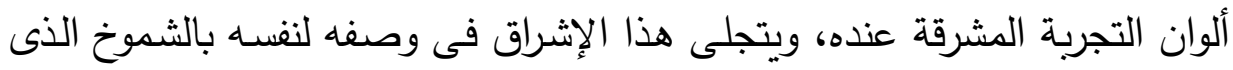

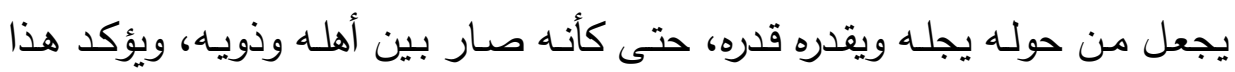

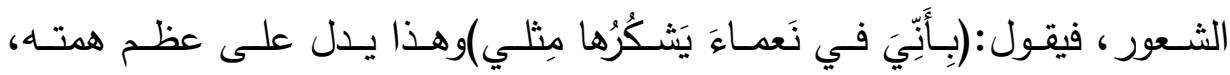

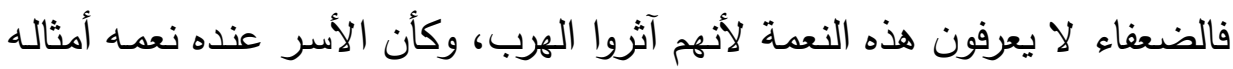

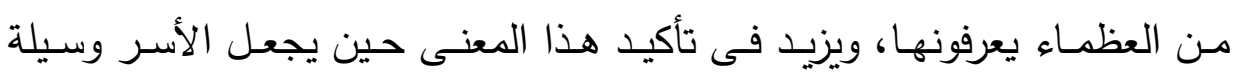
ليتعرف الروم على خلال وفضائل هذا الفارس المقدام.

$$
\begin{aligned}
& \text { (1) السابق ص.0.0، } 01
\end{aligned}
$$

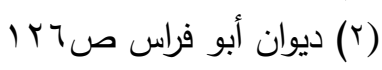


الاغتراب بين أبى فراس والمعتمد بن عباد - دراسة وموازنة

وقد بلغ الأمر بأبى فراس أن يحتقر الأمستق (ملك الروم) فيكيل لله السباب

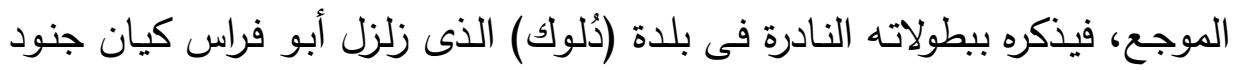

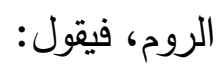

فَأَبصَرَ صيغَةَّة اللَيثِ الهُمـامِ

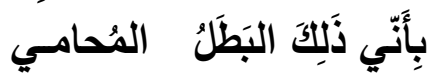

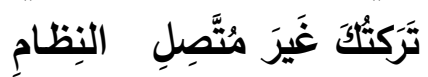

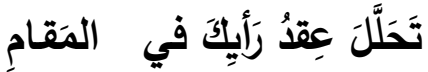

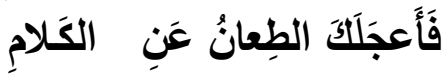
حَمى جَفَيَكَ طيبَ النَومِ حامِ

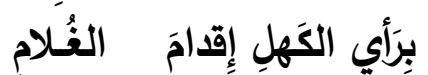
وَلا وُصَِلَت سُعودُكَكَ بِالتَمامِ (')

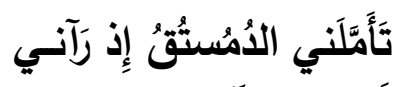

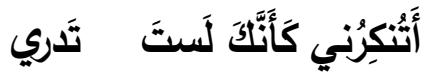

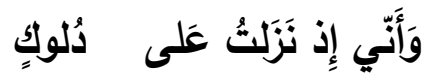
وَلَمَّا أَنْ عَقَدَتُ صَليبَ تَأِيِي

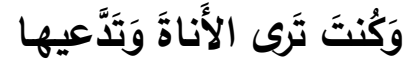

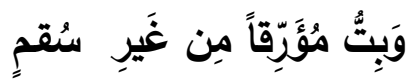

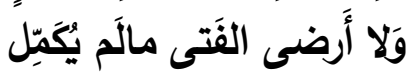
فَلا هُنَّنَتَها نُعمى بِأَسِري

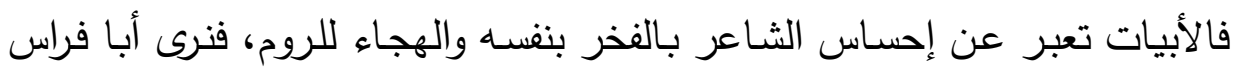

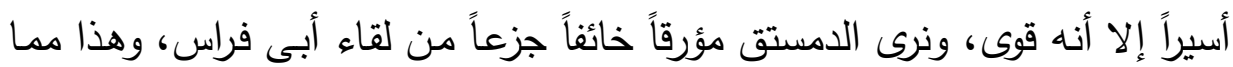
يكشف عن مظهر جديد من مظاهر الفخر عند أبى فراس.

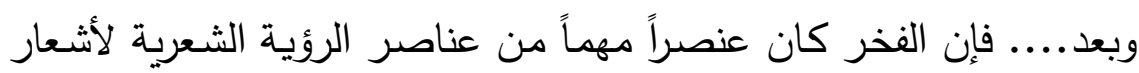
الاغتراب عند أبى فراس، وهو أهم غرض فى رومياته، وقد تتوعت ملامسح هذا

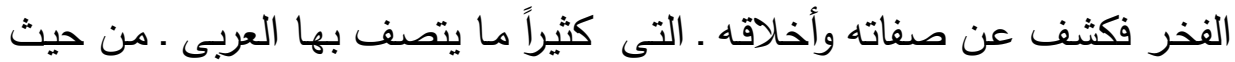

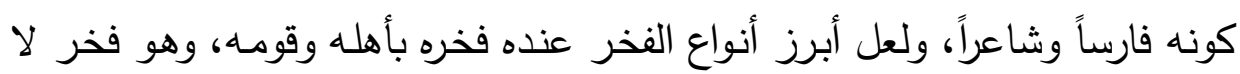

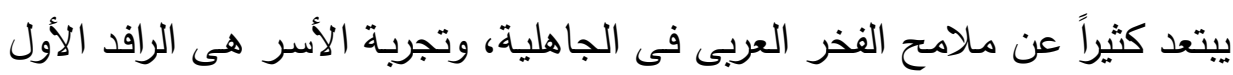
لهذه الأشعار الذى كثف فيها عن علو نسبه رغم حياة الأسر التى يحياها.

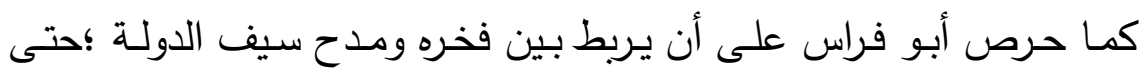

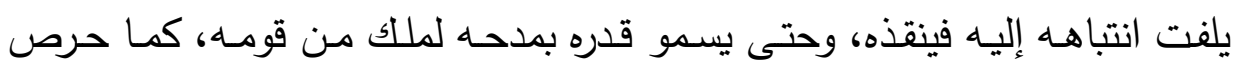

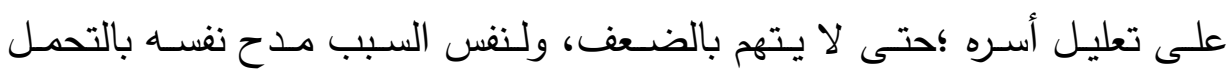
والصبر على الأغلال، كما ألهب أعداءه بكلماته الموجعة التى تكثف بلف عن ترفعه وعدم تصنعه لهم كما يفعل الجبناء.

( ) (1) ديوان أبو فراس ص ا17 
الاغتراب بين أبى فراس والمعتمد بن عباد - دراسة وموازنة

وهكذا ظهرت أفكار ومعانى الفخر بـارزة فى روميات أبى فراس حتى لا

تكاد تخلو منها قصيدة.

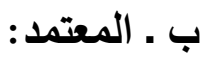

تمثلت معانى الفخر واضحة جلية عند أبى فراس وتتوعت تنوعاً ظاهراً فى

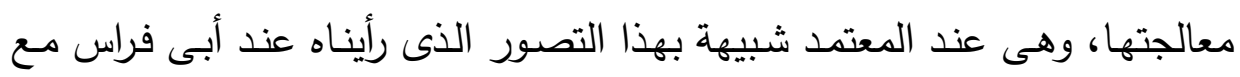
مراعاة الطبيعة الثاعرية بينهما، وأثر التجربة وفاعليتها فى رسم أجواء الفكرة.فقد كانت آثار السـن قويـة الأثر على نفس المعتمـد، وربمـا كان إحساسـه بـانفلات

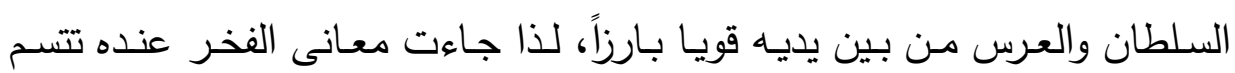

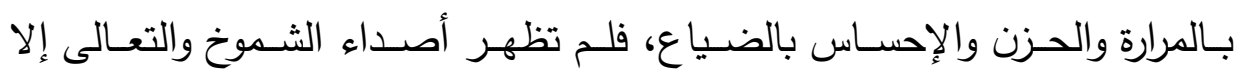
ومضـات خاطفة حين ترتسم فى مخيلة المعتمد ذكريـات المجد الغابر والسلطان

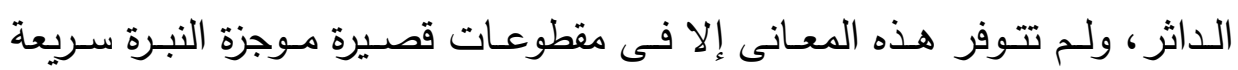

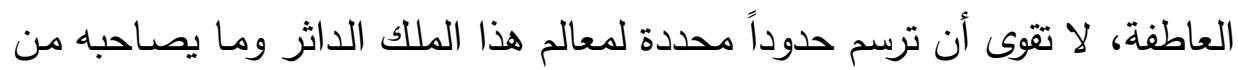

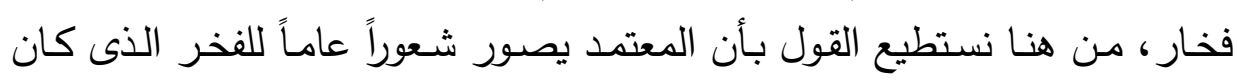

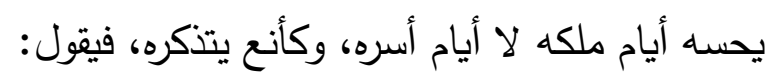

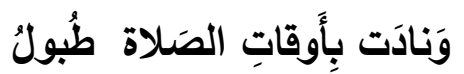

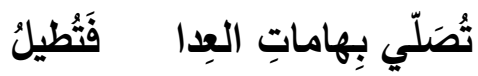

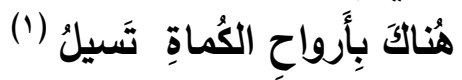

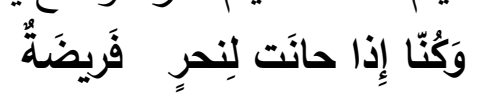

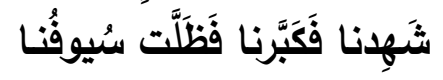

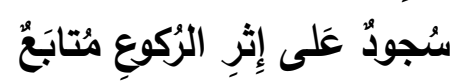

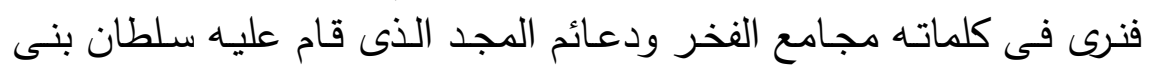

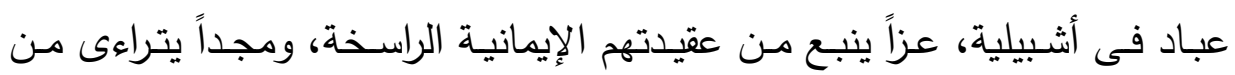

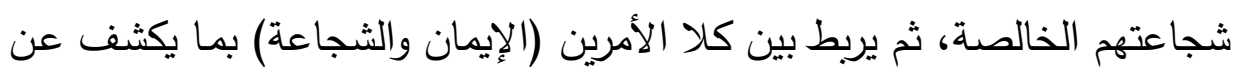

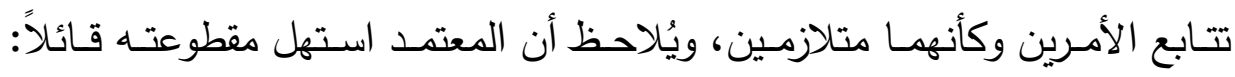

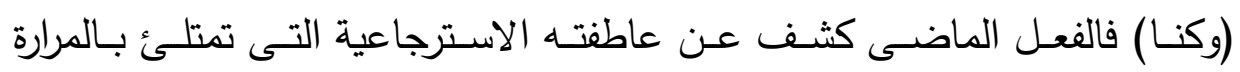

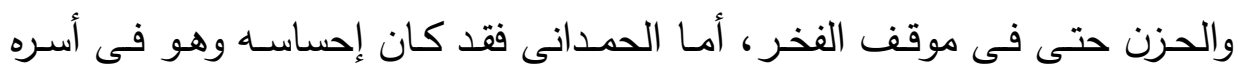

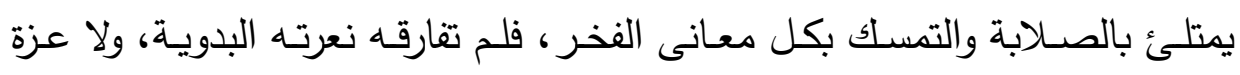

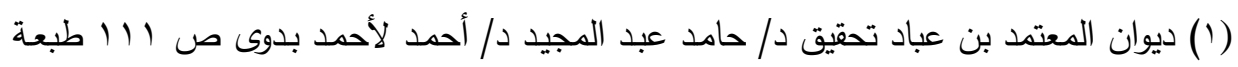

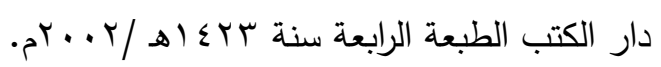


الاغتراب بين أبى فراس والمعتمد بن عباد - دراسة وموازنة

نفسـه العربيـة، ولا شموخه التغلبى، ولا سلطان قومـه الحمدانى، خاصـة وأن ملك

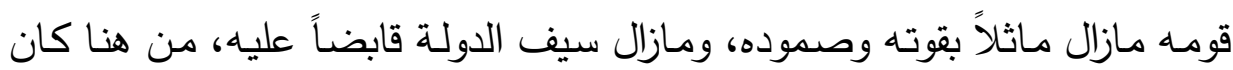
إحساسه بالفخر أقوى، وروافده تترقرق فى أبياته بصورة واضحة.

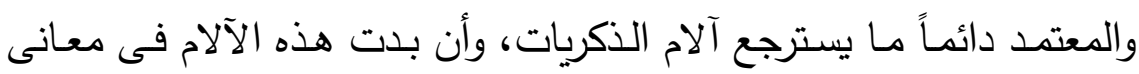

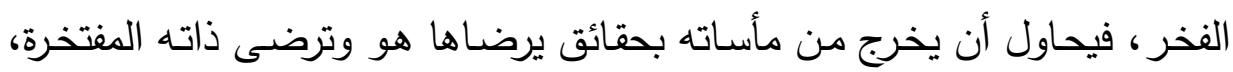

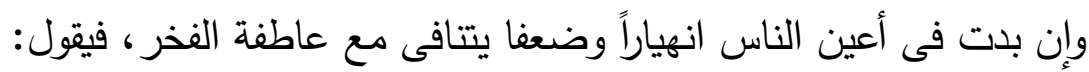

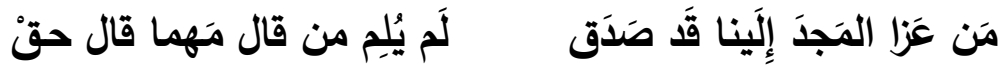

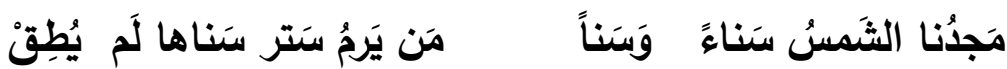

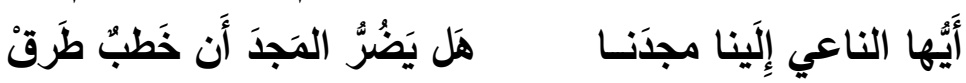

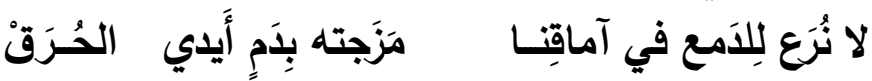

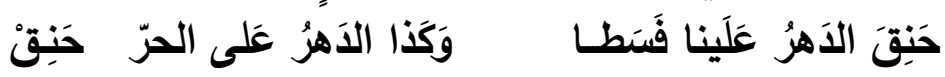

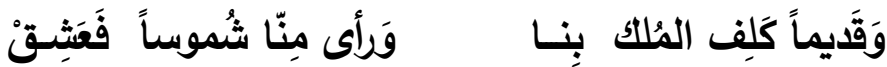

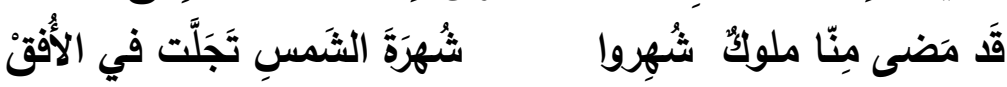

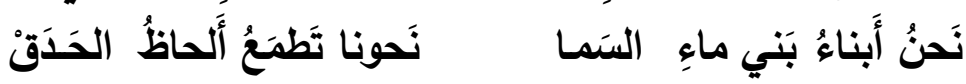

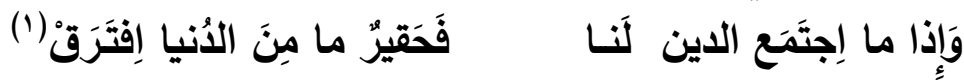

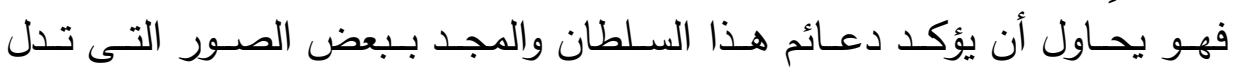
علدالغلبة، فهم شمس لا تستطيع أى قوة أن تستر نورها، وهم على قدر من الدين

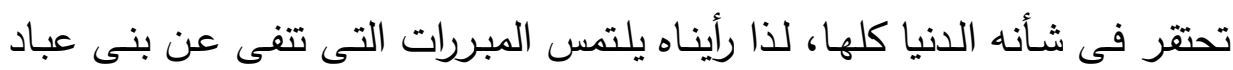

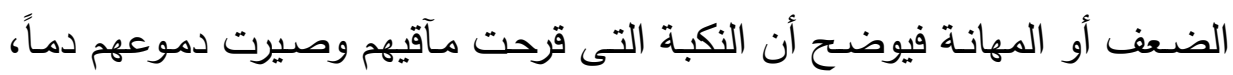
جاءت من سطوة الدهر الذى لا يسطو إلا على الأقوياء (وكذا الدهر على الحر

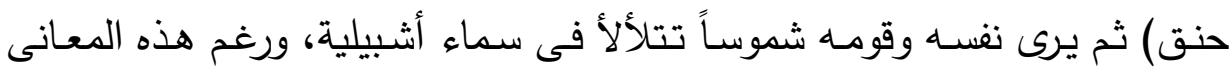

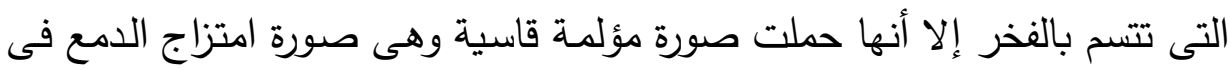
مآقيهم بدم فهى تكثف عن مشاعر الحزن والقسوة والحرمان الذى يعانيه المعتمد

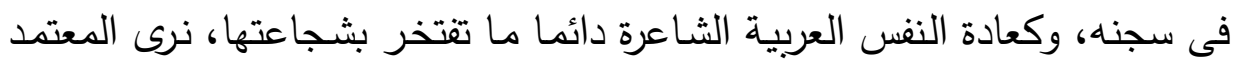

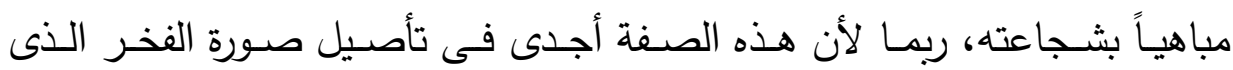


الاغتراب بين أبى فراس والمعتمد بن عباد - دراسة وموازنة

يحاول المعتمد أن يرتفع بها عن مذلة السجن وسلب ملكه، وأجدى أنواع الفخر

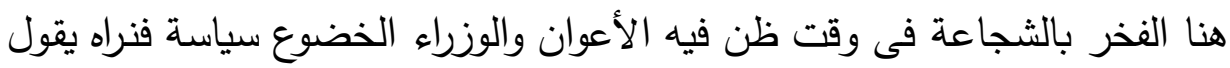
حين هوجمت أشبيلية:

فليبدُ مِنك لَهُم خُضوعُ

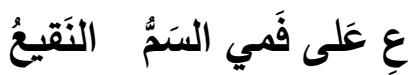
مُلكي وتسلمني الجُموعُ

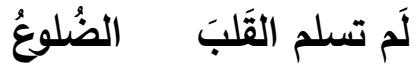
ع أيسلَبُ الثَرفتُ الرَفِيحُ أَلا تُحصّنَني الأُروعُ

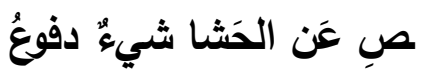

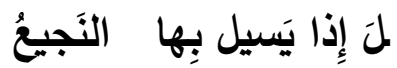

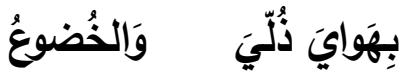

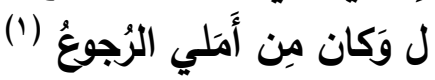

قالوا الخُضوعُ سياسَةُّة

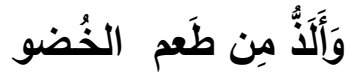
إِن يسلب القَومُ العدا

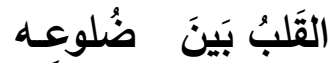

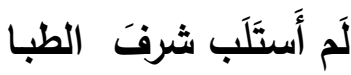
قَد رُمتُ يَومَ نِزْالِهـم

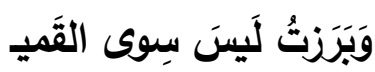
وَبَََلتُ نَفسي كَي تَسي أَجَلي تَأَخَّرَ لَمَ يَكُنْ ما سرتُ قَطٌٌُ إلِى القِتـا

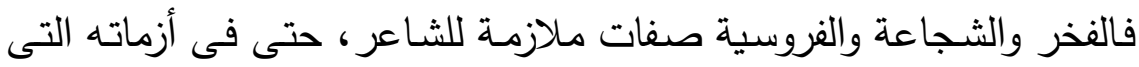

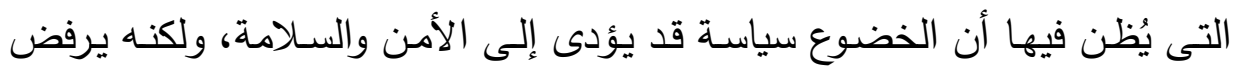

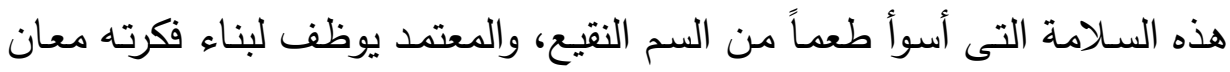
تقوم على أسـاس عكسى، فنراه ينتقل بالصورة من مسـاحة قد يكون فيها مجالاً

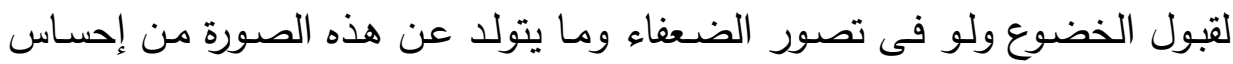

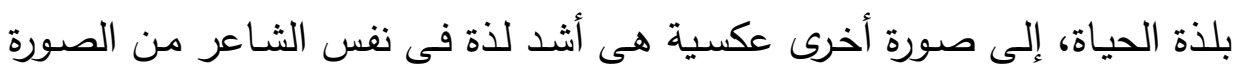

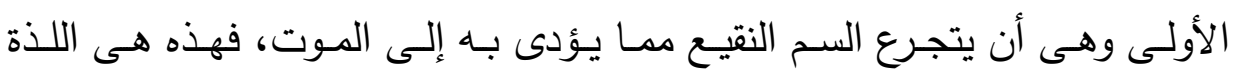
الحقيقية، وهى الأولى بالتقدير فى مثل هذه الته المواقف.

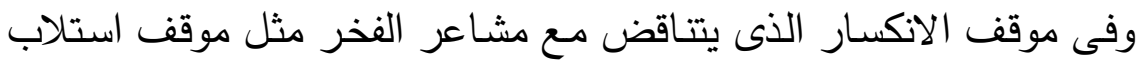

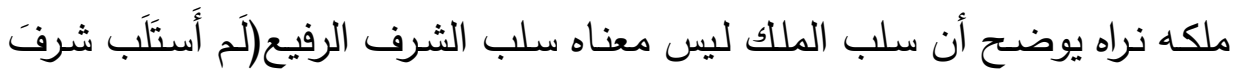

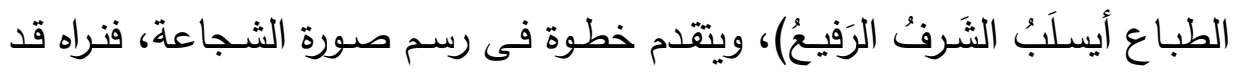

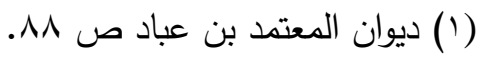


الاغتراب بين أبى فراس والمعتمد بن عباد - دراسة وموازنة

خرج لملاقاة عدوه وليس عليه درع مما يبن عدم خوفهه من الموت، فلم يكن فىى أمله الرجوع من المعركة.

ورغم سيطرة روح الصـلابة والقوة على هذه الأبيات إلا أنها تصور مشاعر

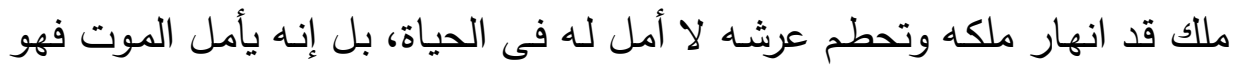
الثئ الوحيد الذى يستحق أن يقبل عليه المعتمد بصدر رحب، وهذا يؤكد عاطفته لأنه

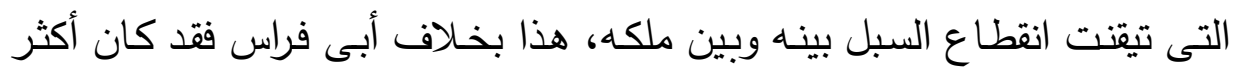

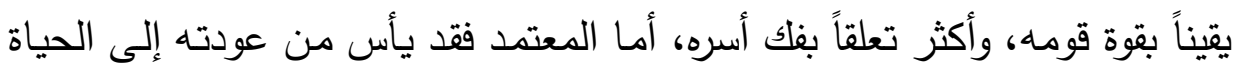
. خارج سجنه ـ التى هى بالنسبة له دار الملك والسلطان، فيقول:

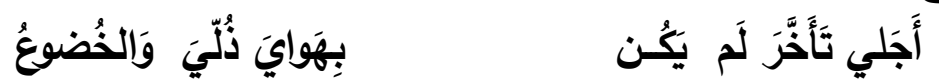
وكأننا به ينتظر أجله، على خلاف لمَّ الحمدانى الذى يقول:

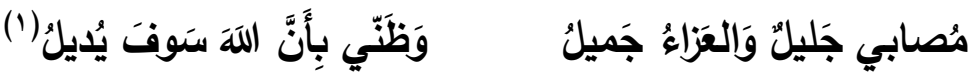

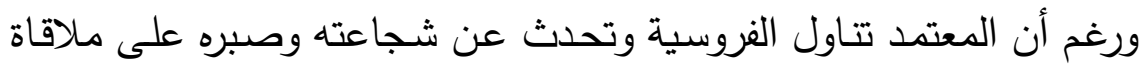

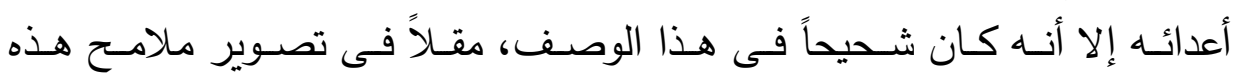

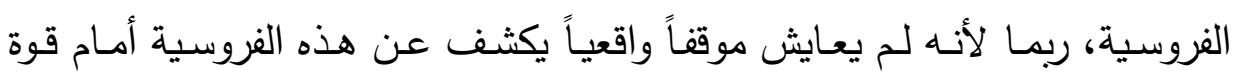
يوسف بن تاشفين، وربما لأن المعتمد كان معنياً بالعلم والأدب أكثر من هن عندايته

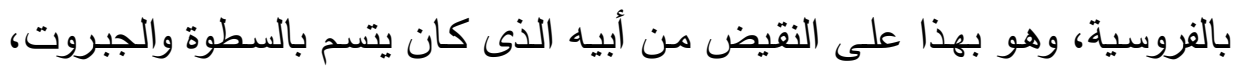

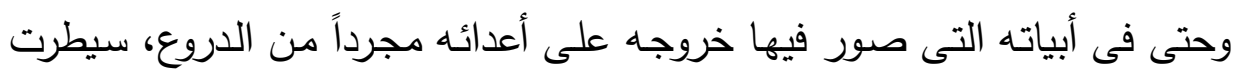

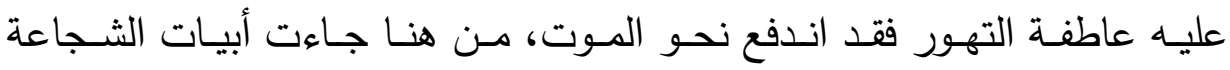

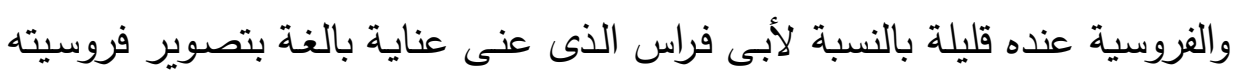

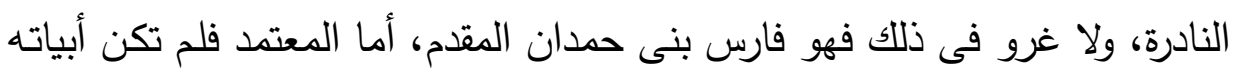
حول الفروسية إلا أبياتاً معدودة من مثل قوله:

وَأن يَمحَ الأنَبَ الَّني كانَ قَََّما

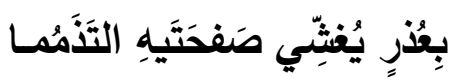

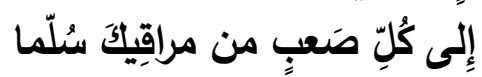

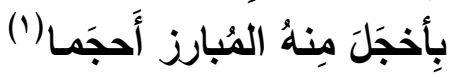

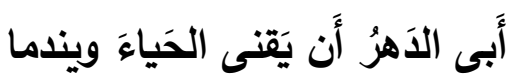

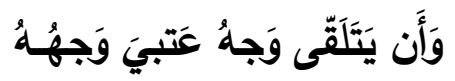

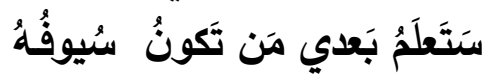

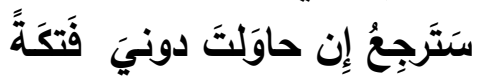

(1) ديوان أبو فراس ص 0با 
الاغتراب بين أبى فراس والمعتمد بن عباد - دراسة وموازنة

فهذهـ شـجاعة رجـل يشـكو آلام السـجن وتسـيطر عليـه عاطفــة الاستسـلام

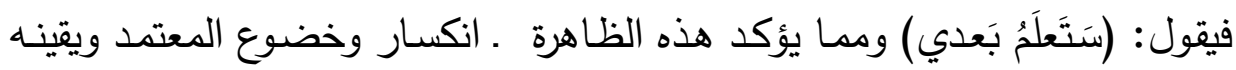

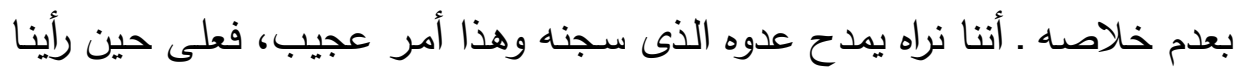
أبا فراس يسب الروم ويرميهم بأقبح الصفات، فتارة يرى ملك الروم مذموم الفعال

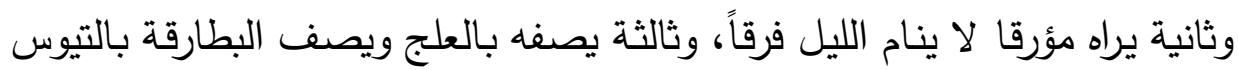

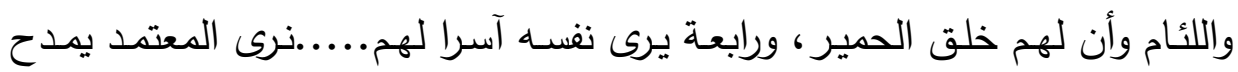

رَايَنا الجَزيَرَة لِكُفــر دارا

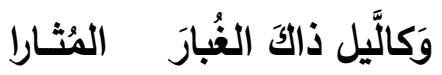

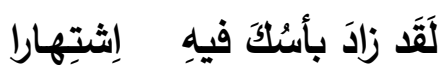

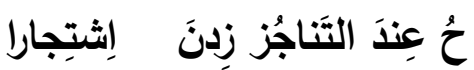

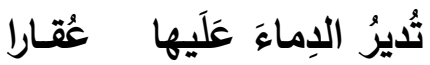

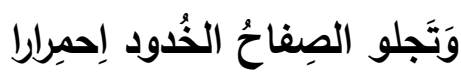

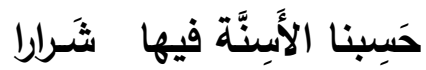

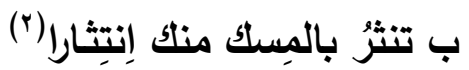
يوسف بن تاشفين، فيقول:

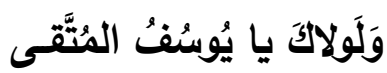

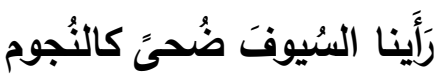

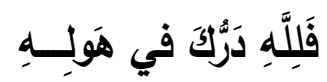

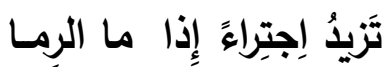

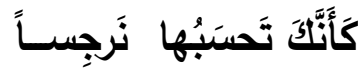

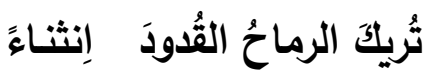
إذاذا نار حربكَ ضَرِّمنتَهـا

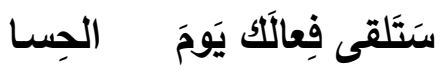

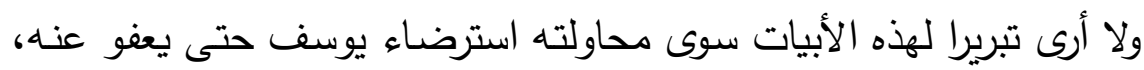

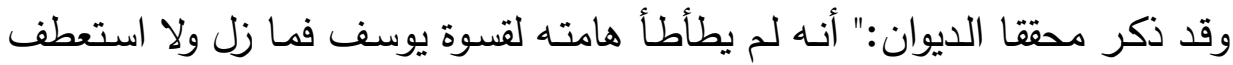

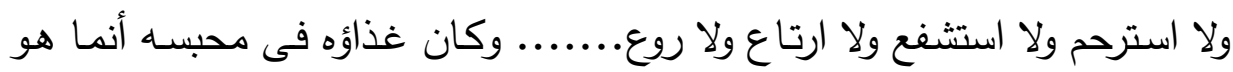

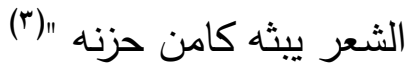

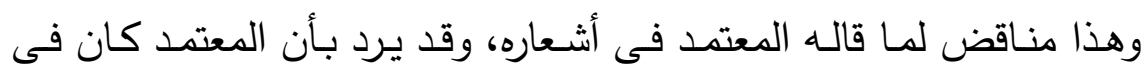

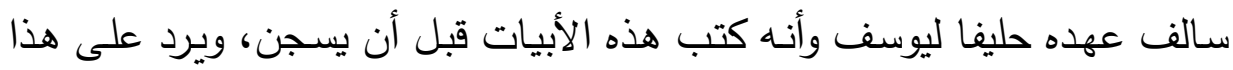
بأن المعتمد حين نزل بأغمات وطلب من حواء بنت تاشفين خباء عاريـة فاعتذرت

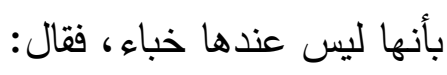

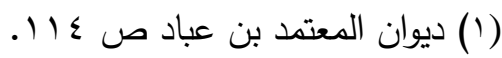

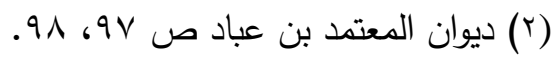

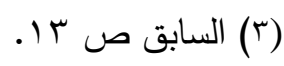


الاغتراب بين أبى فراس والمعتمد بن عباد - دراسة وموازنة - ــ

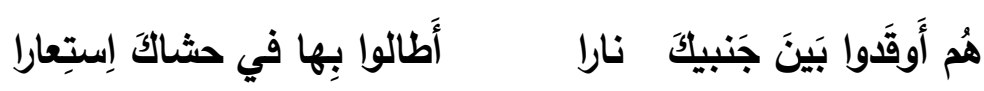

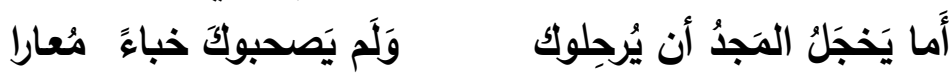

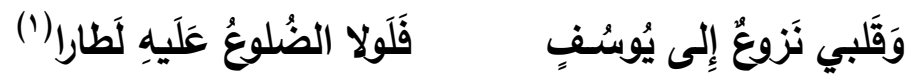

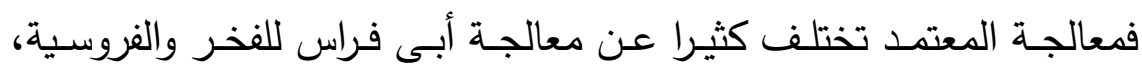

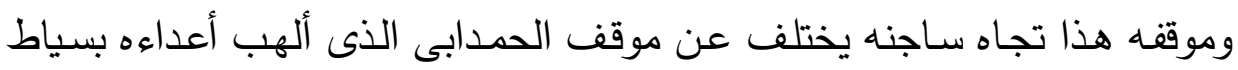

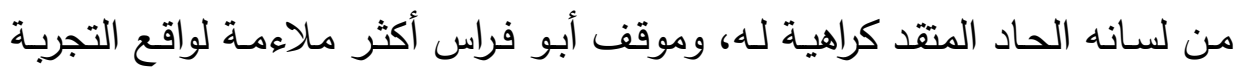

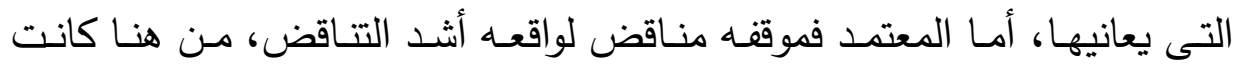

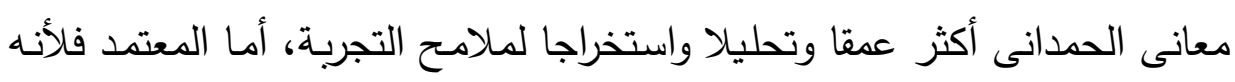
يمدح عدوه بدت بعض الدلائل التى تكثف عن إحساسه وضيقه بالسجن فيقول: وَقَلَبي نَزْوعُ إِلى يُوسُسـفِ

فهذا القلب يكشف عن قلبه السجين بين الضلوع يتمنى أن يطير من سجنه كأمنيته أن يتحرر من سجنه اللعين. وبعد فهذه هى أهم مظاهر الاختلاف بين أبى فراس والمعتمد فى غرض بنه الفخر . 
الاغتراب بين أبى فراس والمعتمد بن عباد - دراسة وموازنة

\section{ثانياً: الصبر والتحمل}

\section{أ:عند أبى فراس}

من أهم العناصر الموضوعية لشعر الأسر عند شاعرينا الحديث عن الصبر

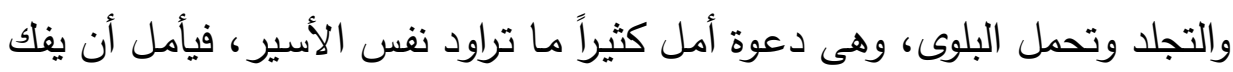

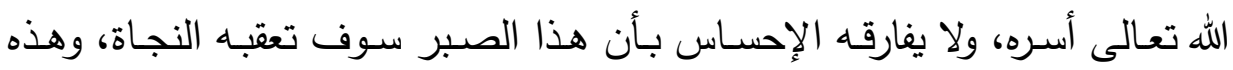

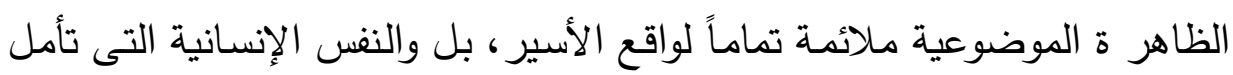

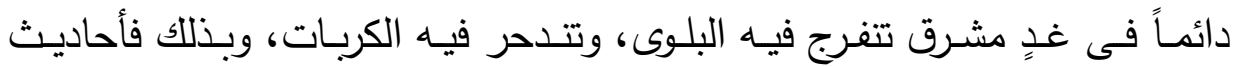
الصبر أنيس النفس ورفيقها فى هذه المواقف.

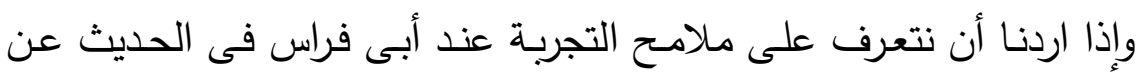

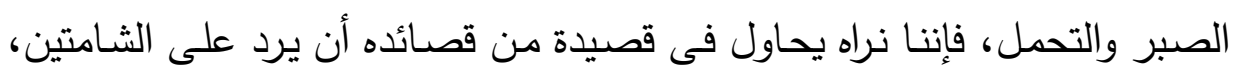

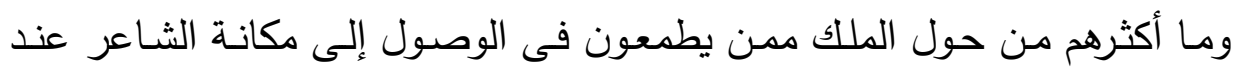

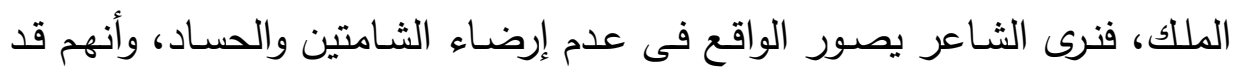
اجتمعوا على قلب واحد من الكراهية والوجد على أبى فراس، يقول:

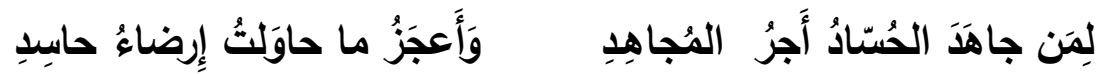

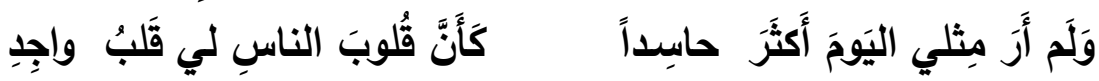

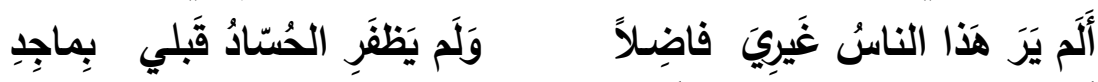

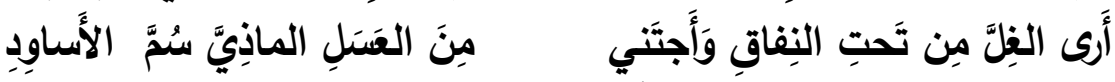

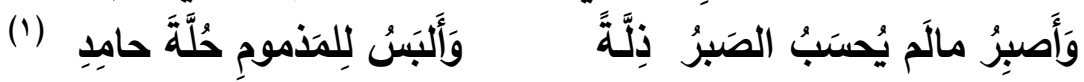

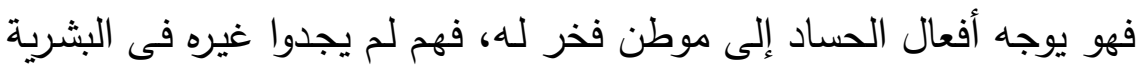

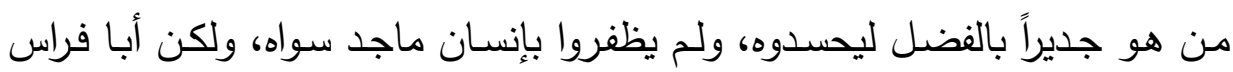

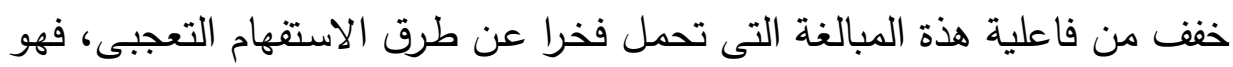

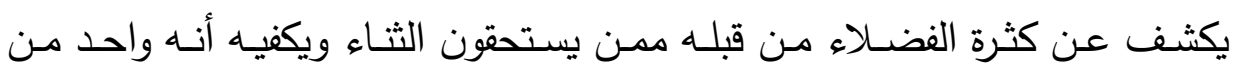

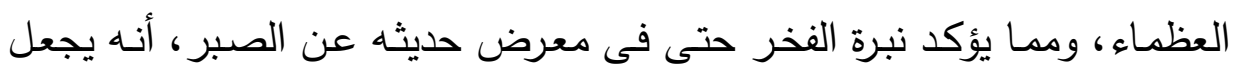

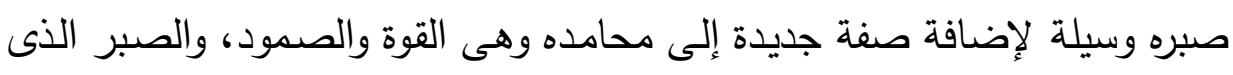

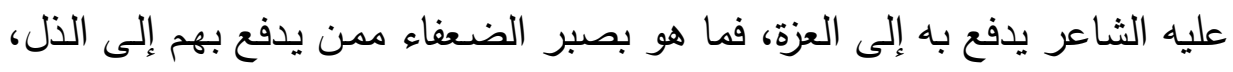

$$
\text { ( ) (') ديوان أبو فراس ص ro }
$$


الاغتراب بين أبى فراس والمعتمد بن عباد - دراسة وموازنة - تل

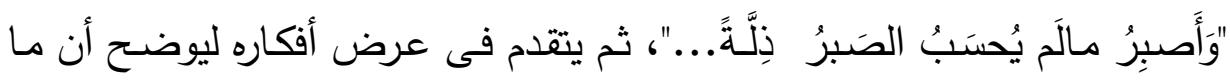

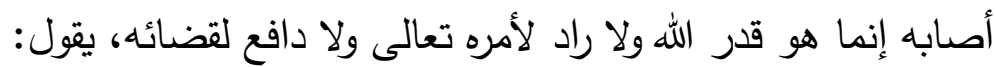

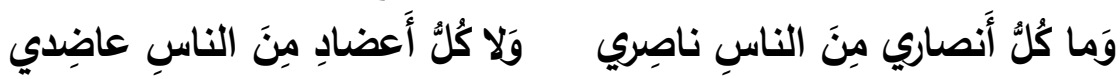

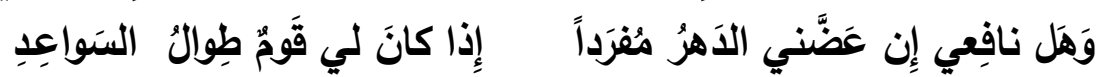

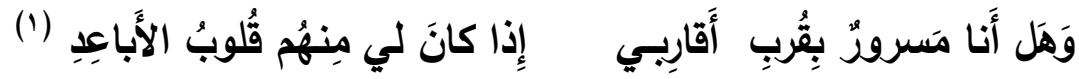

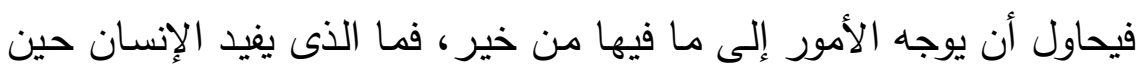

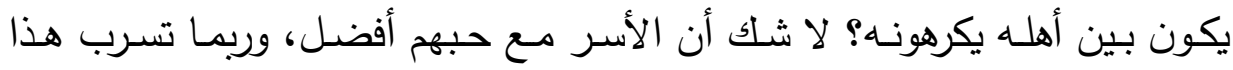

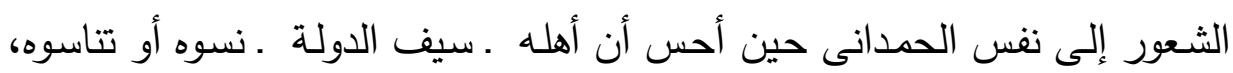

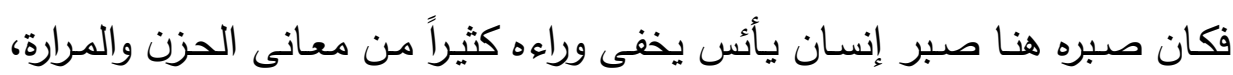
وبعضاً من الاستسلام فنراه يقول:

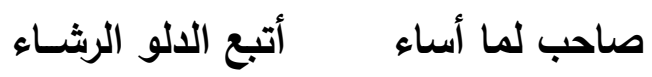

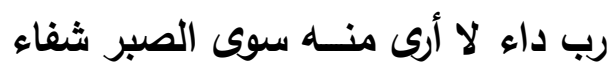

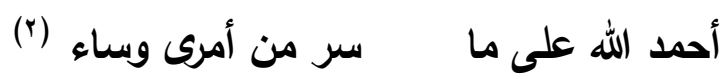

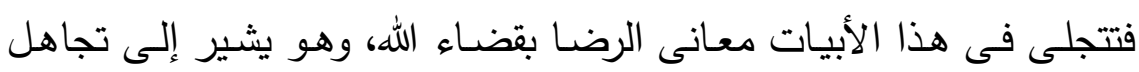
سيف الدولة لله ونسيانه لله في الأسر . هدل الابيات ومن مظاهر الصبر والتجلد صبره على بعد الأحبة، فيقول حينمـا ماتت

فَلَألفِيَنَّنَ لَهُ صَبهورا

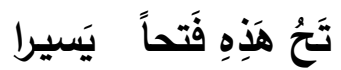

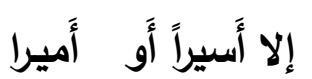

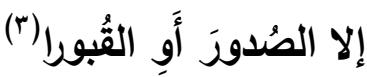

وَلَئَنْ رُميتُ بِحادِثٍ

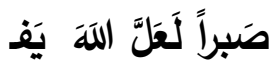

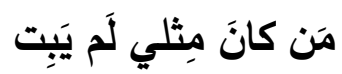

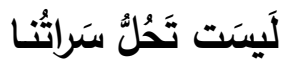

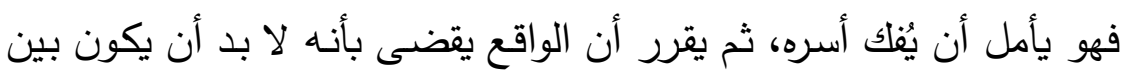
أمرين:القتل أو الأسر وهذا يكثف عن عزة نفسه وعزيمته القوية ونفسه الأبية.

$$
\begin{aligned}
& \text { (1) ديوان أبو فراس ص سم (1) }
\end{aligned}
$$

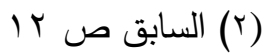

$$
\begin{aligned}
& \text { (r) السابق ص (r) (ץ) }
\end{aligned}
$$


الاغتراب بين أبى فراس والمعتمد بن عباد - دراسة وموازنة

$$
\text { وفى قصيدة أخرى نراه يوصى أمه بالصبر فيقول: }
$$

عَلَيَّ وَإِن طالَ الزَمَانُ طَويـلُ

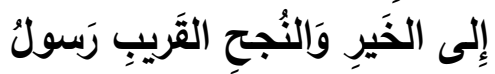
عَلى قَََرِ الصَبرِ الجَميلِِ جَزيلُ

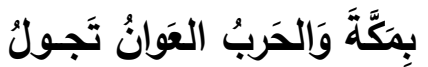

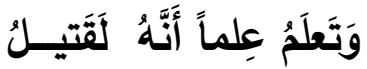

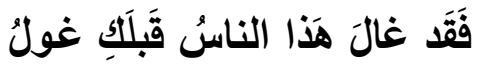

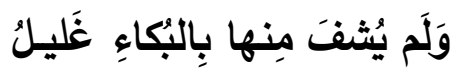

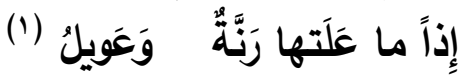

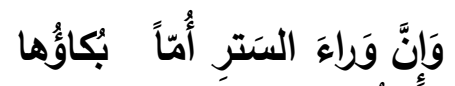

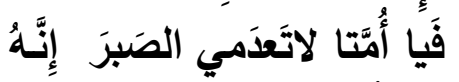

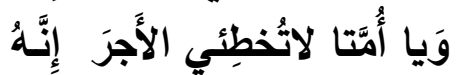

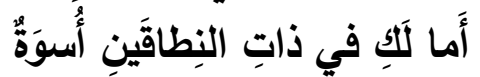

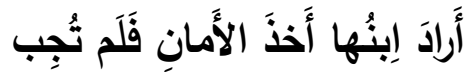

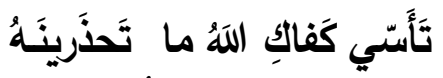

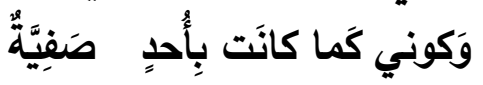

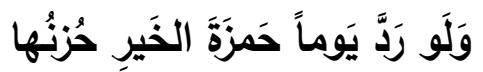

فنراه يستلهم التاريخ محاولاً إلقاء هالة من الجلال عليه، فيربط بين مصناب فئ أمسه فيه

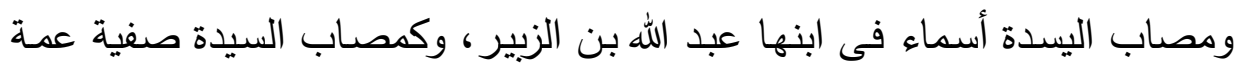

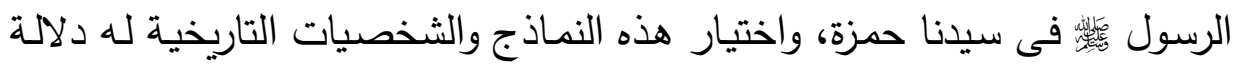
فكرية تكثف عن تجربة الشاعر وإحساسه بذاته المتعالية. ونراه فى قصيدة أخرى يوصى أمه بالصبر والتحمل، فيقول:

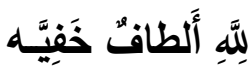

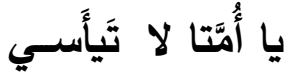
هُ وَكَم كَفانا مِن بَلِيَّهِ

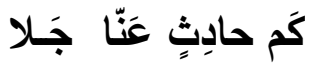

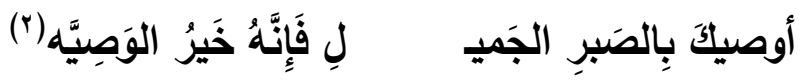

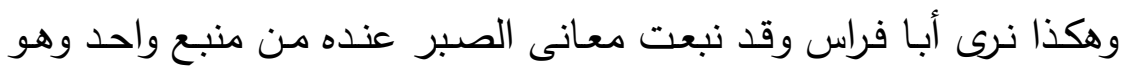

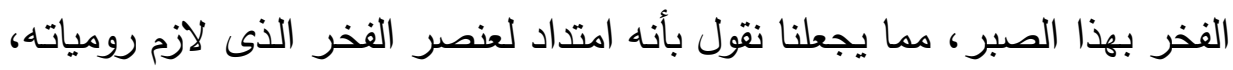

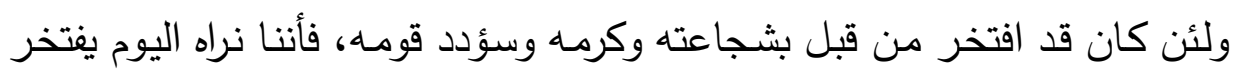

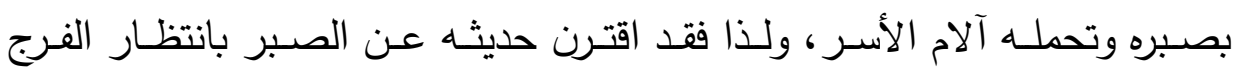
والخلاص من هذا الأسر المقيت.

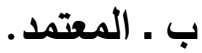
أما المعتمد فقد نظم قصيدة واحدة فى حديثه عن الصبر ، يقول:

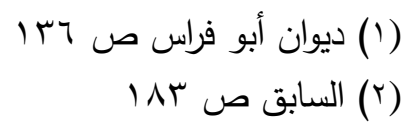




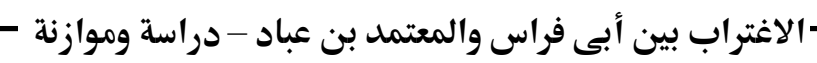

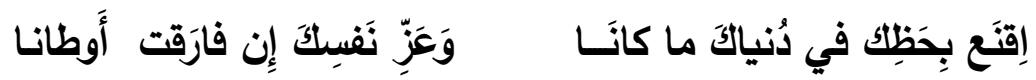

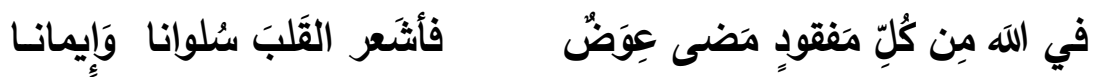

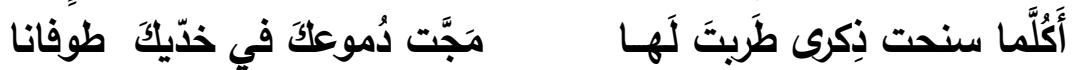

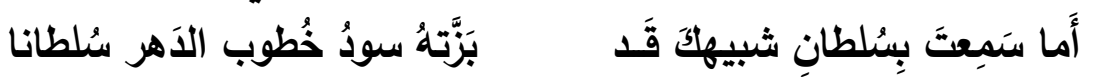

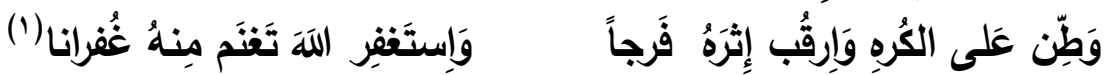
وصبره هنا ليس صبر من ينتظر الخـلاص من السجن، وإنما صبر من من ينتظر الموت، لذا فهو يتحدث فى أسلوب رثائى، نرى فيه القناعة بحظه من الدنيا، ونرى

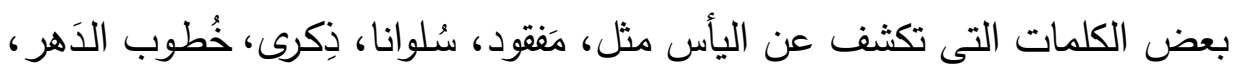

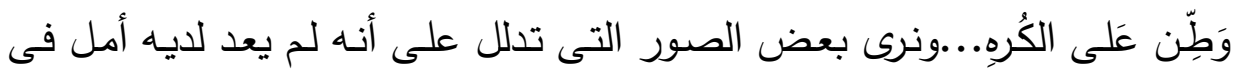
عودة ملكه، ولم يعد لديه مايبذله على هذا الملك الضائع سوى الدموع التى تجرى لتهى

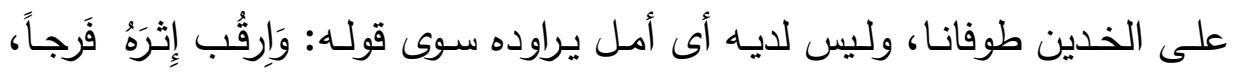

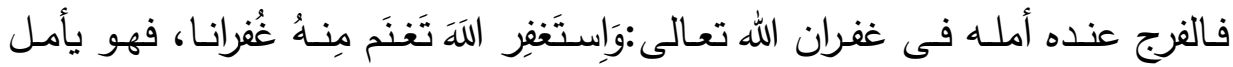
الموت لا الحياة.

وهـذه القصـيدة قصـيرة جداً، ولـئن رأينـاه الحمـدانى مفتخـراً مباهيـاً بقوتـهـ

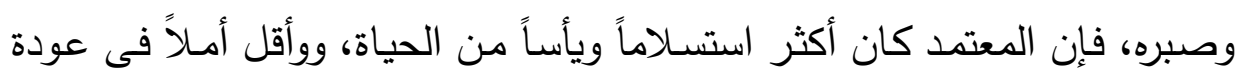
ملكه، لذا فقد كان يأمل الموت ليتخلص من فندان هذا السجن المقيت.

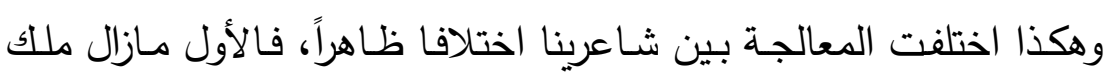
قومه قائما، أما الآخر : فقد زال ملكه، من هنا اختلفت أصداء التجربة. 
الاغتراب بين أبى فراس والمعتمد بن عباد - دراسة وموازنة

\section{ثالثا: الثـكوى}

الثكوى وتصوير الألم أثر طبيعى لتجربة الأسر وانعكاس للشعور النفسى تأسى

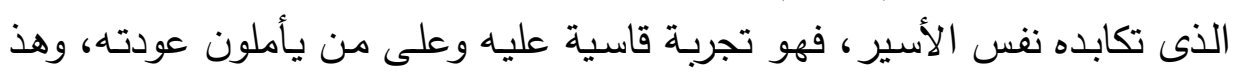

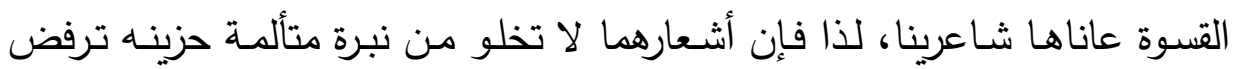
هذا الوضع المهين الذى لا تقبله سوى أنفس العبيد.

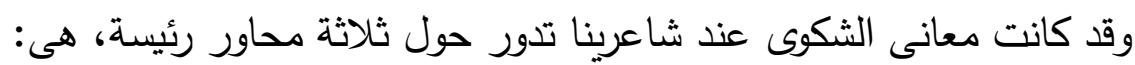
ا ا ـ الشكوى من غدر الزمان وقسوة الأيام.

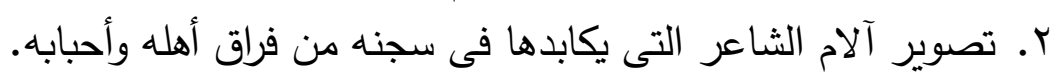
r. الحديث عن أثر القيد والأغلال على نفيهيها.

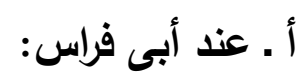
أبو فراس كعادته صـاحب نفس أبيـة مترفعـة حتى وإن كان أسيراً فى يد

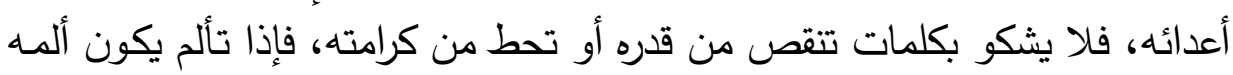

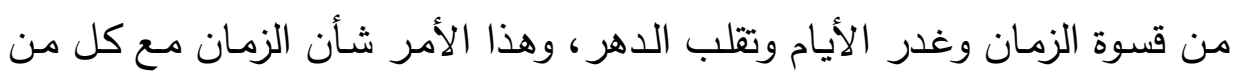

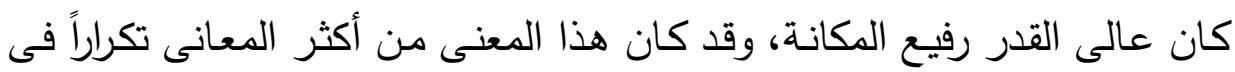

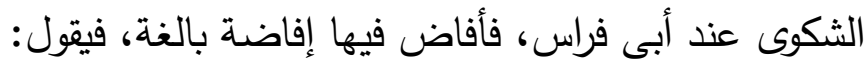

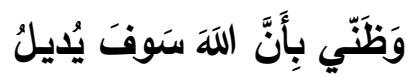

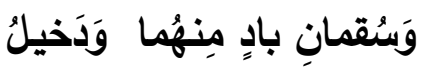

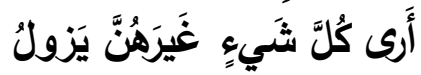

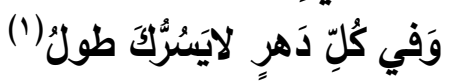

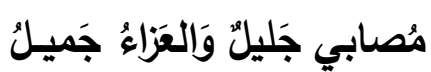

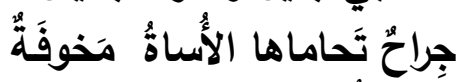

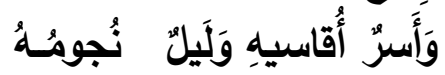

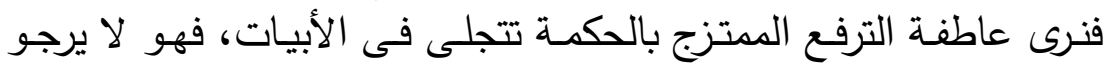

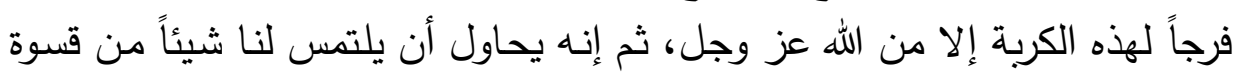

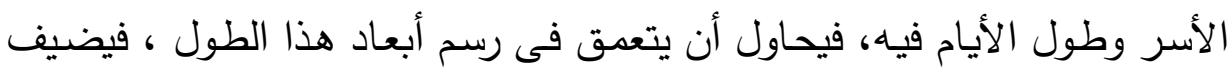

إليه الظلام الشديد، لذا فإن هذا العذاب يحدث آلاما دانها داخلية وخارجية.

ونراه يشكو من قسوة هذا الزمان وعدوانه الثديد عليه، فيقول:

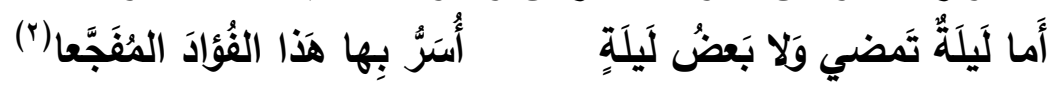

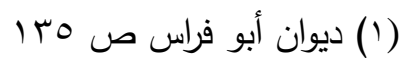

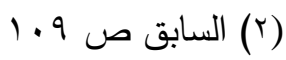


الاغتراب بين أبى فراس والمعتمد بن عباد - دراسة وموازنة

وهذه نبرة مظلمة اصطبغت بها نفس أبى فراس من ظلمات السجن، وربما

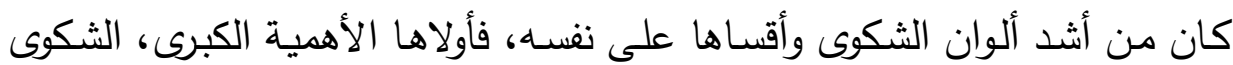

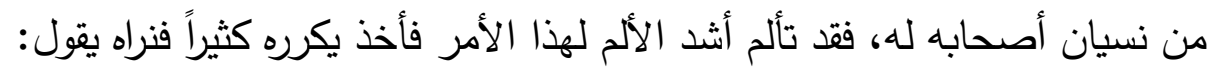

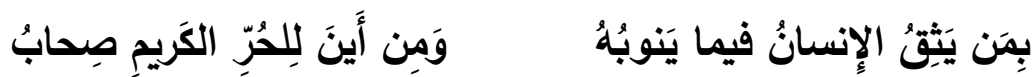

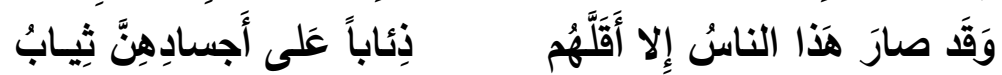

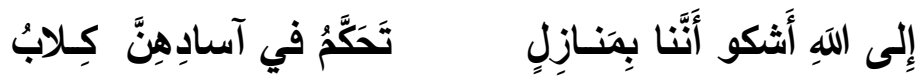

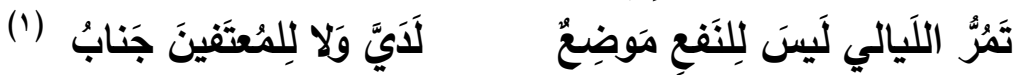

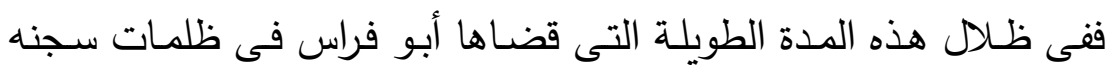
أحس باليأس، حتى بلغ به الأمر أن يتعجب من أن يكون هنالك أصحاب للإنسان

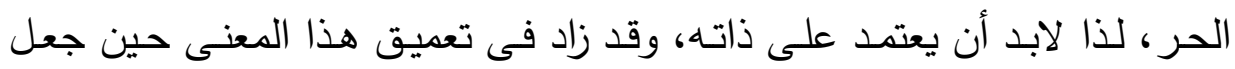

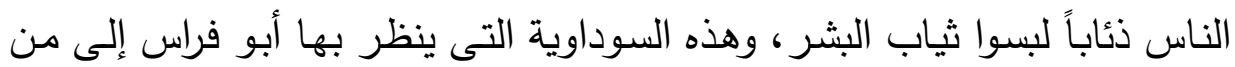

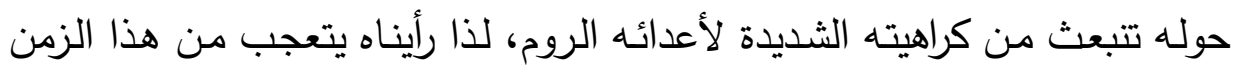

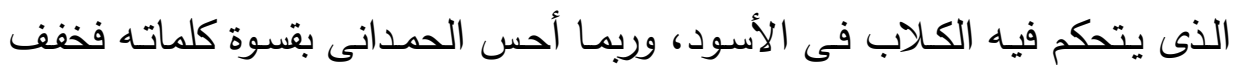

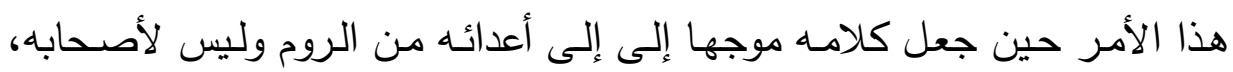

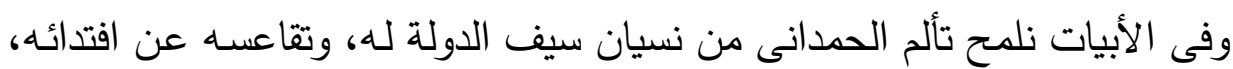

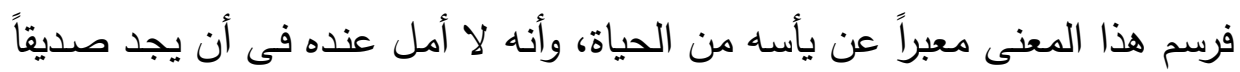
مخلصاً يكون عضداً له فى هذه الكربة التى يقاسيها فيقول:

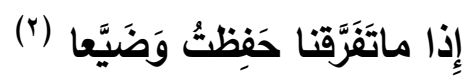

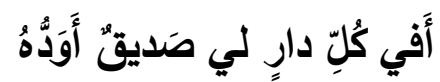

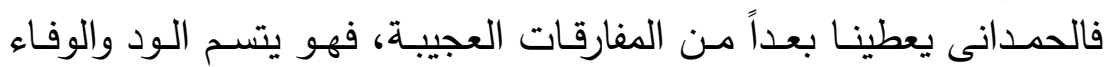

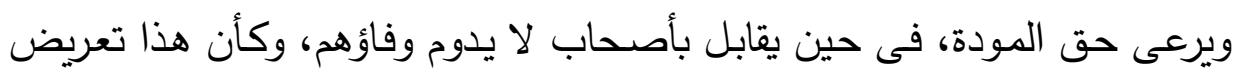
بسيف الدولة، ومما يدل على تألمه من هذا الأمر ، قوله:

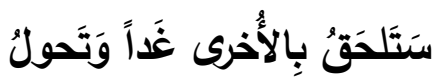
تَناسانِيَ الأَصحابُ ألا عُصَيَّةًَ

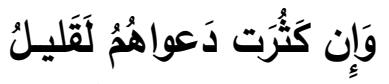

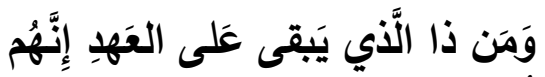

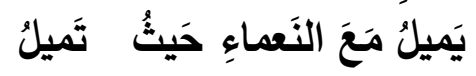

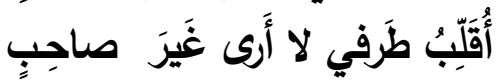

$$
\begin{aligned}
& \text { (1) ديوان أبو فراس ص ساب } \\
& \text { (r) السابق ص ان } 9 \text { (r) }
\end{aligned}
$$


الاغتراب بين أبى فراس والمعتمد بن عباد - دراسة وموازنة

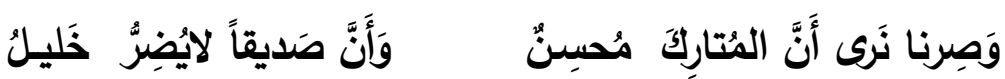

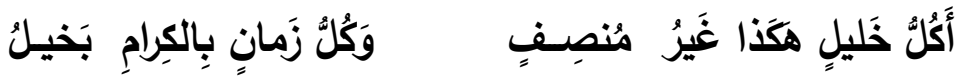

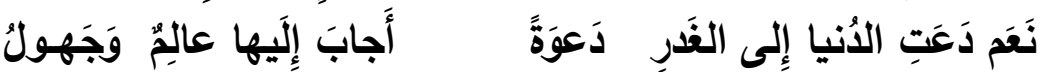

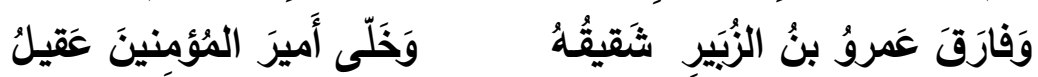

فَيا حَسرَتا مَن لي بِخِلِّ مُوافِقِقِ

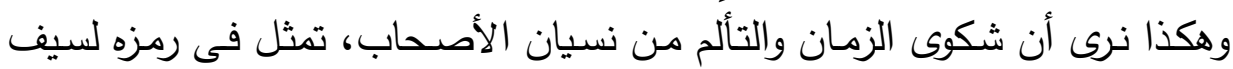

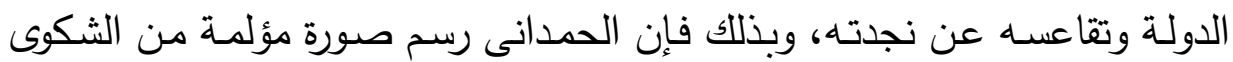

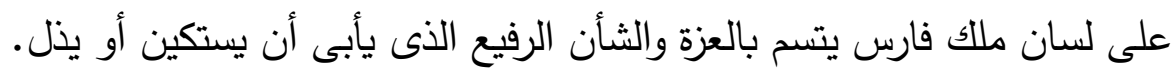

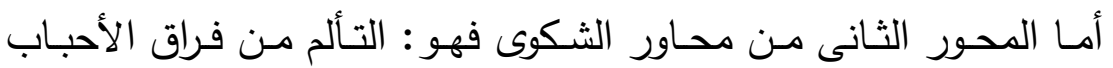
والأهل، وقد كانت المناسبات التى يسعد فيها أبوفراس بمصاحبة أحبابه وأهله قبل فيل فرئ

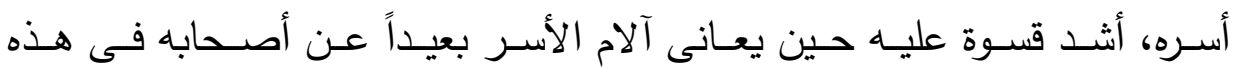

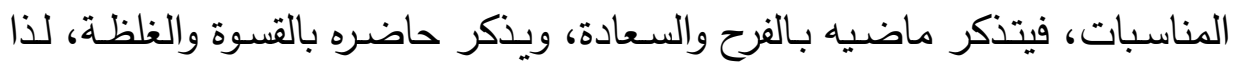
رأيناه فى مناسبة العيد يتذكر أهله، فيقول:

عَلى مُعَنّى القَلبِ مَكروبِ

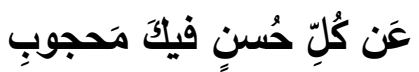

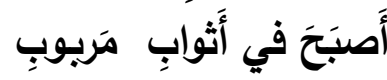

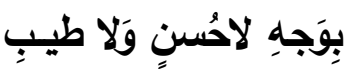

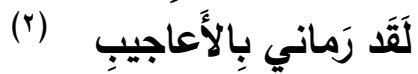

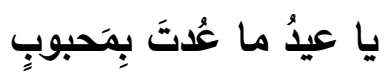

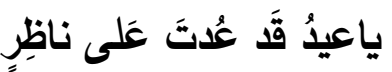

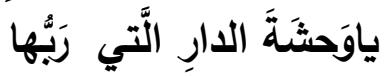

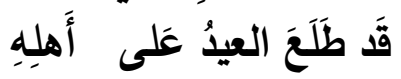

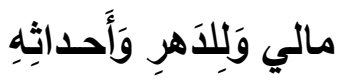

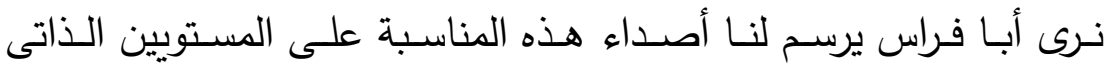

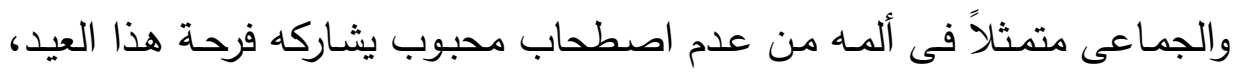
والمستوى الجماعى فى أثر هذا العيد على أهله وحزنهم على فقدان رب هذا البيت

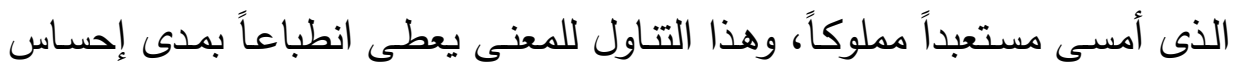
الحمدانى بنفسه وإعجاب من حوله به وافتقادهم لله. ونراه يوضح العلاقة الوطيدة بينه وبين أهله وأنهم منه بمثابة القلب فيقول: بله

$$
\begin{aligned}
& \text { (1) ديوان أبو فراس ص بـا (1) }
\end{aligned}
$$

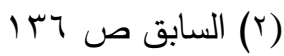



دَمعُعُ في الخَدِّ صَبُّب
إِنَّ في الأَسَرِ لَصَبَّاً
وَلَكلهُ في الشامِ قَلبُ (1)
هُوَ في الرومِ مُقِيمٌ

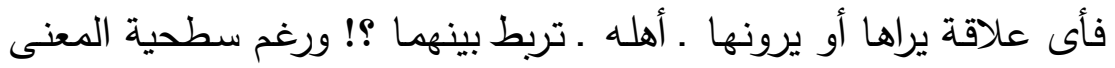
فى البيتين إلا أنهما يكثفان عن ألمه الثديد لفراق أهله وأصحابه.

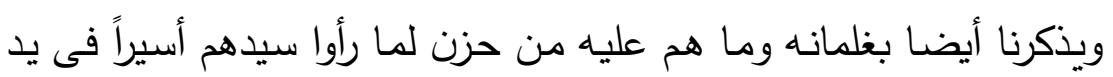

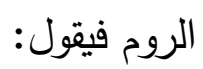

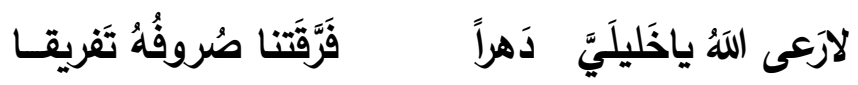

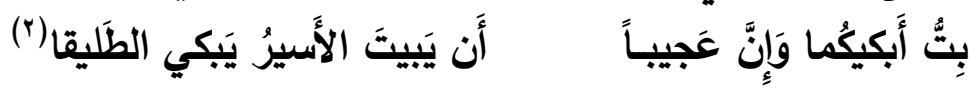

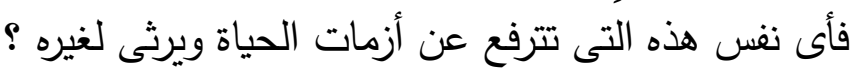

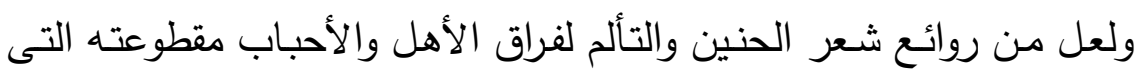
خاطب فيها حمامة كانت تتوح بقربه، يقول فيها:

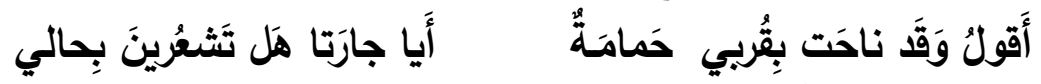

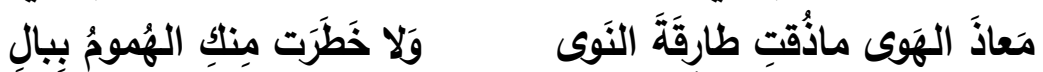

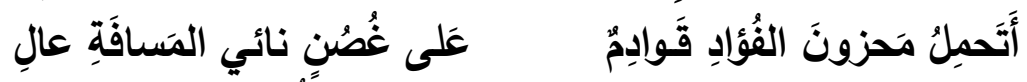

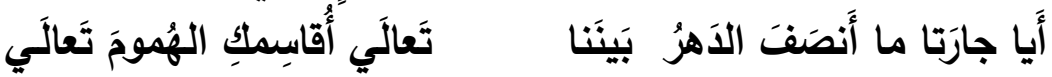

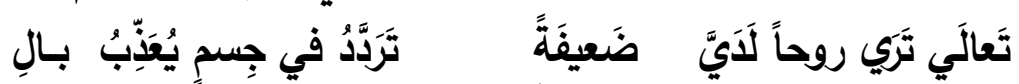

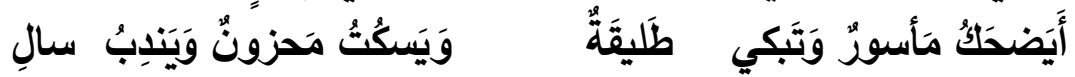

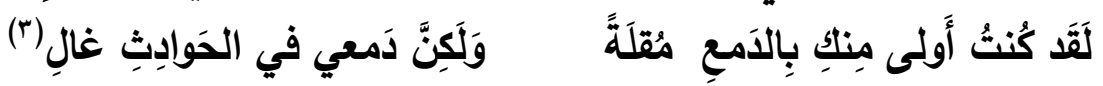

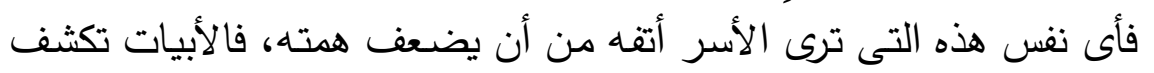

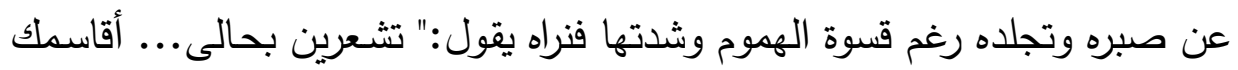

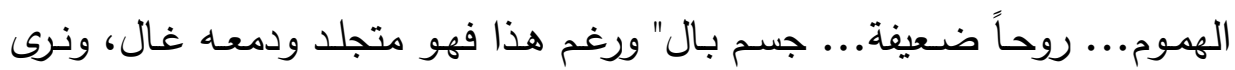

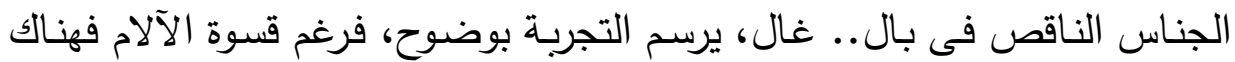
عزة وترفع عن البكاء.

$$
\begin{aligned}
& \text { (1) السابق ص اس (1) } \\
& \text { (r) ديوان أبو فراس ص آ (r) } \\
& \text { (r) السابق ص ديون ابو صراس صr }
\end{aligned}
$$


الاغتراب بين أبى فراس والمعتمد بن عباد - دراسة وموازنة

ومما يلحق بباب الثكوى تصوير أثر القيود والأغلال ولم يستطرد الحمدانى

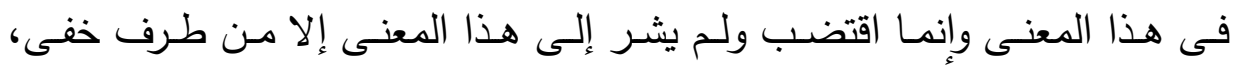
فيقول:

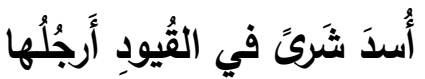

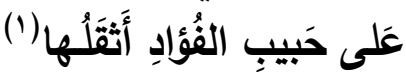

يامَنْ رَأى لِي بِحِصنِ خِشَنَةِة

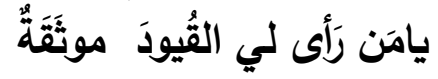

وقلة تناول هذا المعنى يكثف عن ترفعه وعدم اعتنائه بأعدائه، وهكذا نرى لهي نفس الحمدانى مترفعة شامخة حتى فى تصوير آلام السجن.

ب ـ المعتمد.

أمـا المعتمد فقد كـان أكثر أنينـاً فى شكواه، بـل إن معـانى الشكوى والألم كانت من أكثر المعانى وروداً فى شعر الاسـر عنده، فقد بلعت أربعا وعشرين أنساني

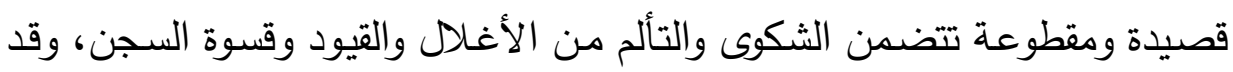

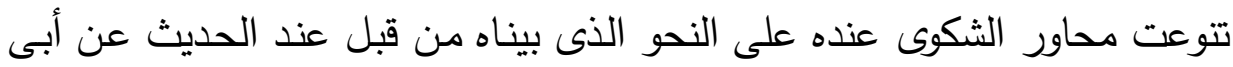

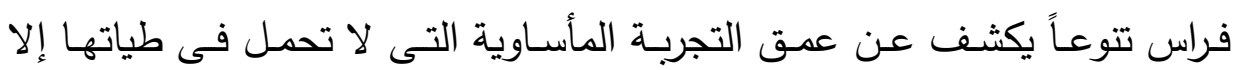

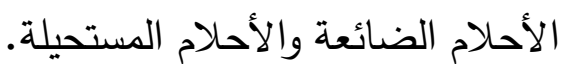
وقد تتوعت محساور هذه الأشـعار بـين الشكوى مـن غدر الأيسام وقهـر الزمان، وبين تصوير الذل والإهانة التى يعانيها الشاعر من تكبيله بالأغلال، فنراه

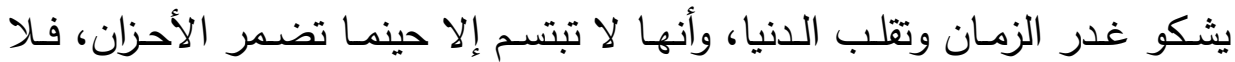
يَنتظر منها خيراً، ولا يَرجو منها عطاءً، فمن يراقب آمال الدنيا يفاجأ بأنها سراب:

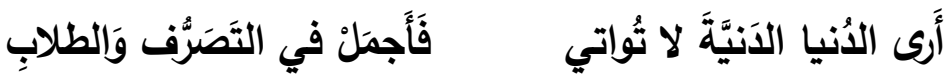
وَلا يَغْرُرَكَ مِنها حُسنُ بُرِدِ

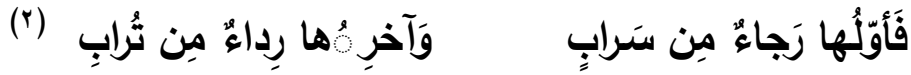
وهذه المقطوعة تكثف عن إحساس عميق جاء من توظيف المعتمد المقابلة

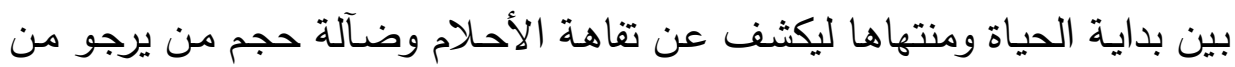

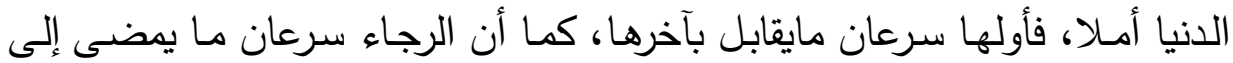

$$
\begin{aligned}
& \text { (') ديوان أبو فراس ص r (1) }
\end{aligned}
$$

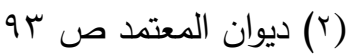


الاغتراب بين أبى فراس والمعتمد بن عباد - دراسة وموازنة

سراب، والأبيات تكثف إحساس الثاعر بتقارب الأثياء وتجانسها رغم ما يوهم الواقع

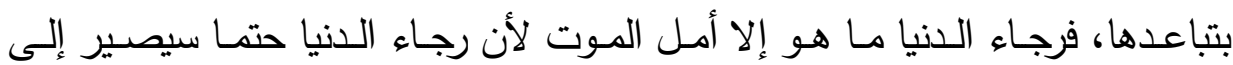
سراب، وثياب الموت حتما ستصير إلى رماد فالكل يبلى. ورغم هذا المعنى السوداوى الذى ينظر به المثابه المعتمد إلى الدنيا فإننا نراه فى بيتين

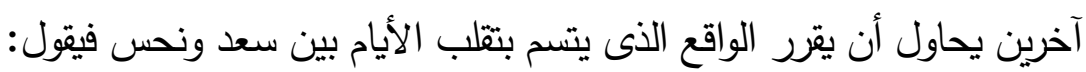

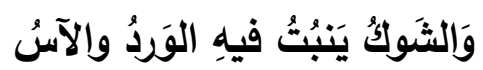

فَقََّمَا جَرحت إلا إنتَنَت تاسو

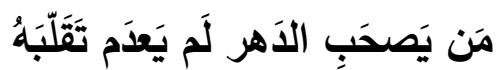

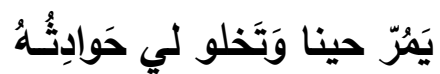

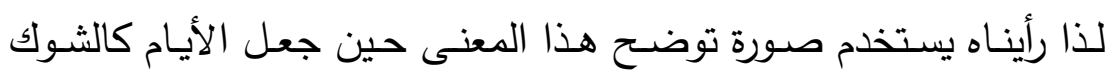

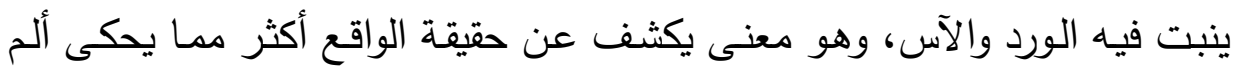

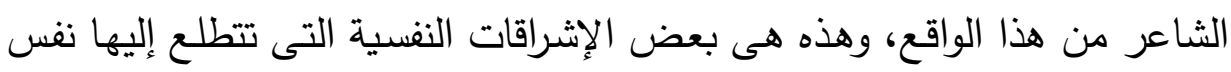

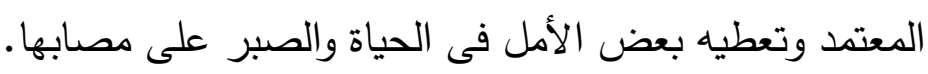

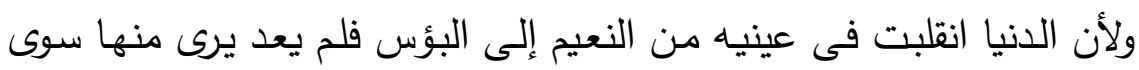
الشوك، نراه يتمنى الموت الذى هو خير من هذا الأسر ، فيقول وقد دعا لـه بالبقاء

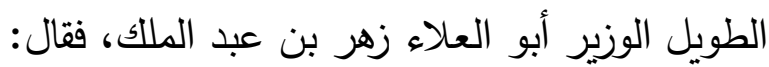

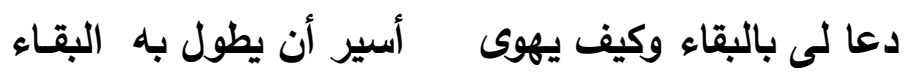

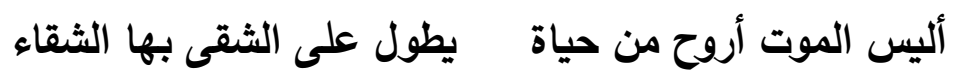

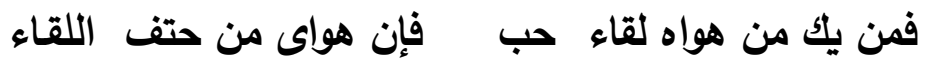

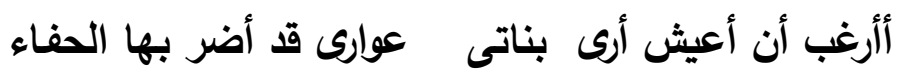

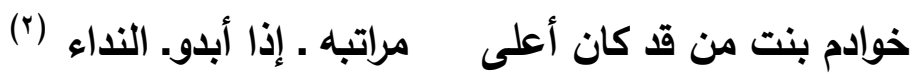

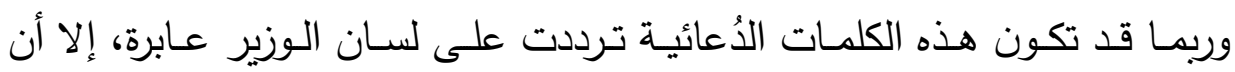

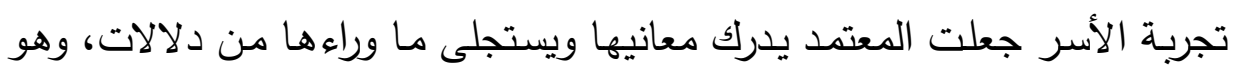
يتمنى ضدها من تمنى الموت والخـلاص من السجن، وتتجلى فداحة الكارثة حين نرى المعتمد يأسى لبناته حين يراهن خوادم لم كانت مرتبته عند المعتمد أيام ملكه

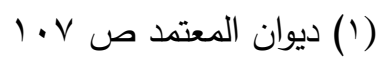

$$
\begin{aligned}
& \text { (r) السابق ص (1) }
\end{aligned}
$$


الاغتراب بين أبى فراس والمعتمد بن عباد - دراسة وموازنة -

لا ترقى إلى كونـه منادياً على باب قصره، فهل هناك فى هذه الحالة أفضل من

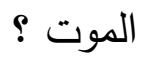

كمـا أجـاد المعتمـد حين أوضـح المفارقـة الشـديدة بـين الماضـى والحاضـر

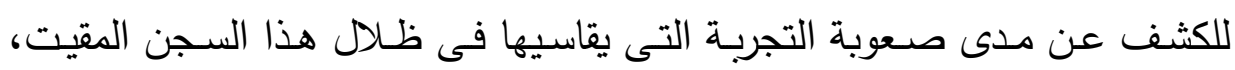
فنرى براعة التعبير عن انقلاب الزمان عليه فقد أمسى كل من كان عوناً له عوناً عليه:

بذأُلِّ الحَدياِ وَثِقَّل القُيـود

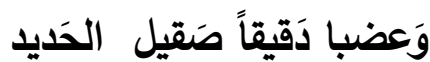

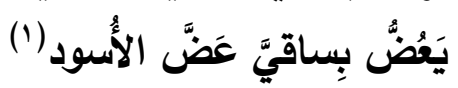

تَبَدلتُ مِن عزَّ ظلِّ البُنودِ وَكانَ حَديدي سناناً ذَليقاً

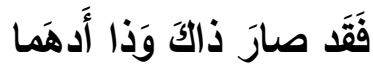

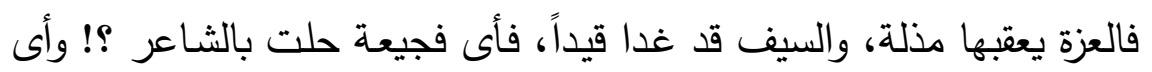
عوادى انقلبت عليه حتى صار إلى هذا الوضع المقيت ؟عابها ويقول مصوراً المفارقة بين الماضى السعيد والماضى البئيس:

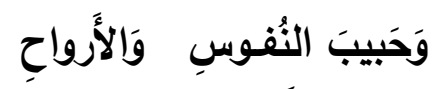

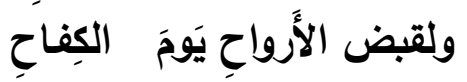

يُقِحمُ الخَيَل في مَجال الرِماحِ

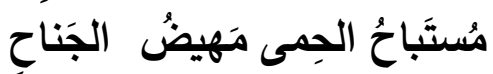

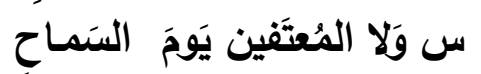

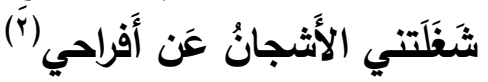

كُنتُ حِفَ النَدى وربَّ السَماحِ

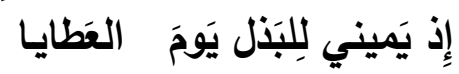

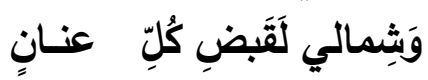
وَأَنا الَيوَمَ رَهنُ أسبرِ

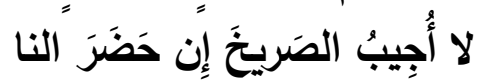

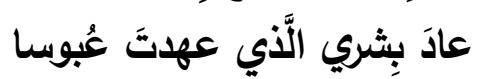

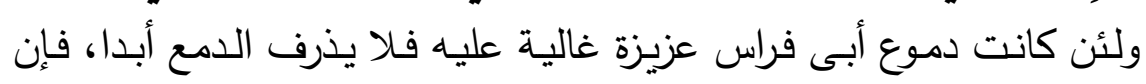

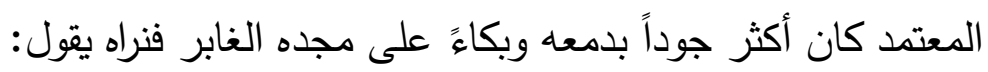

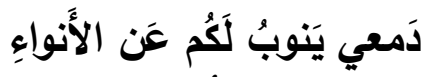

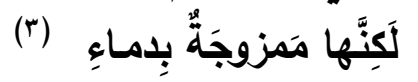

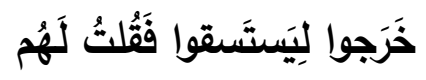
قالوا حقيق في دَمعِكَ مُقِنِعْ

(1) ديوان المعتمد ص ؟ 9 (Y)

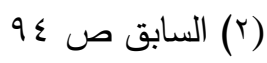
(r) السابق ص 1 (r) 
الاغتراب بين أبى فراس والمعتمد بن عباد - دراسة وموازنة

فالمعنى كما نرى يكشف عن ألم شديد وقسوة يكابدها المعتمد فى أسره فقد

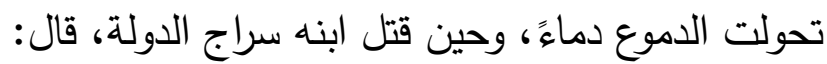

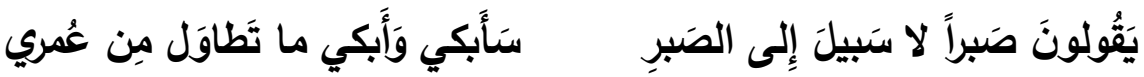

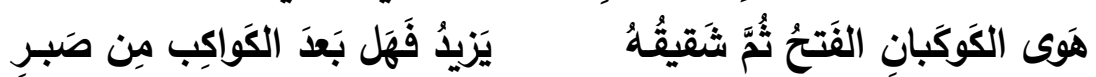

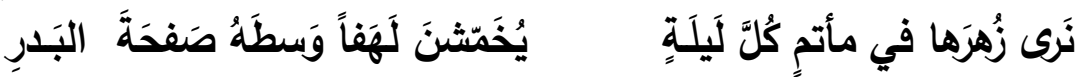

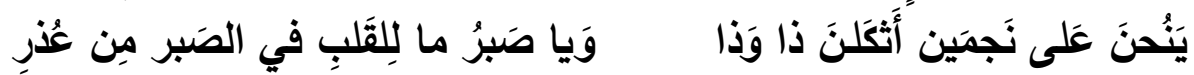

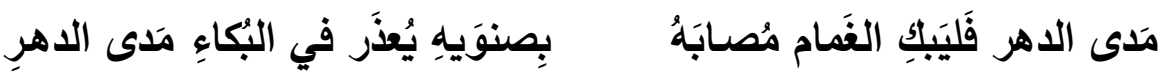

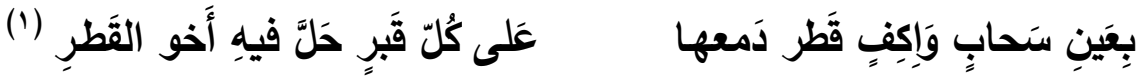
فقد جعل فى هذه القصيدة جميع عناصر الكون تبكى لموت ولديه، والكون كله

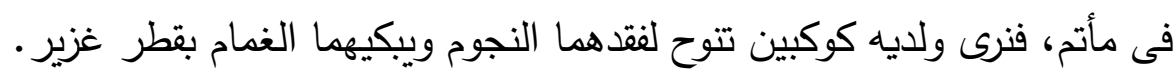

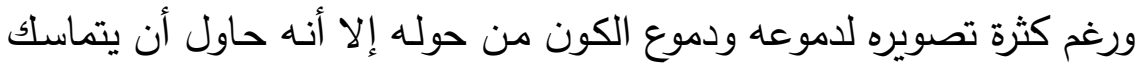

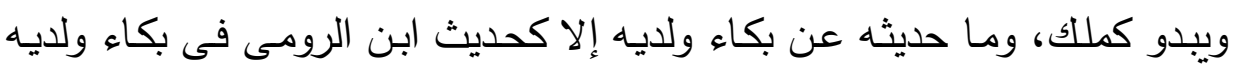
أيضا، فقال:

بكاؤكُما يشْفي وإن كان لا يُجْدي

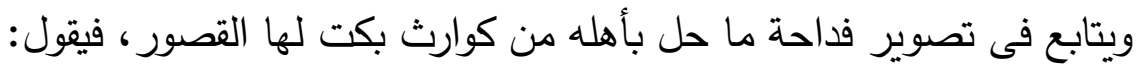

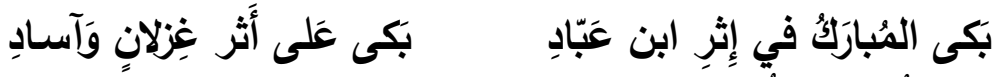

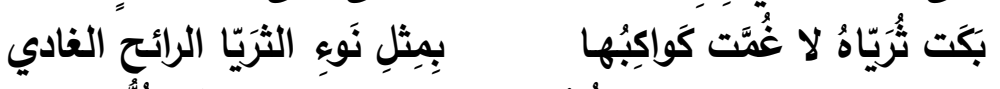

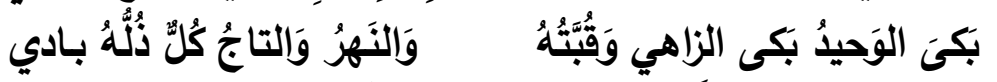

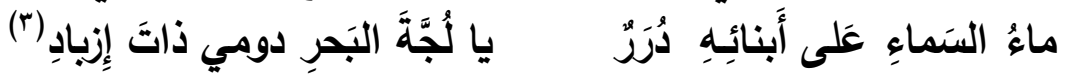

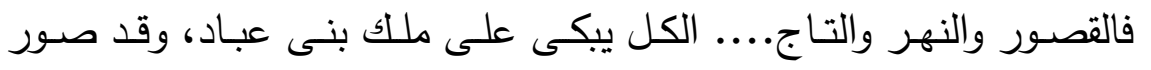

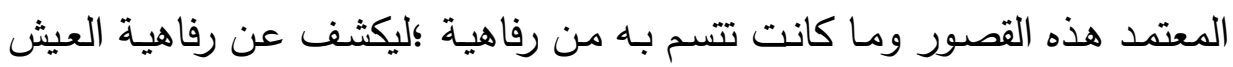

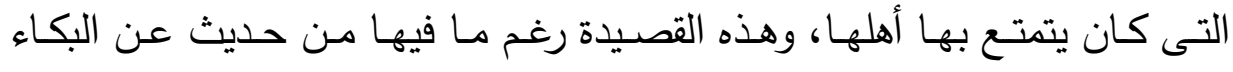
والشكوى من غدر الزمان إلا أنها تتمتع بالإشراق والجمال الذهى يتضح من من حديثه

(1) ديوان المعتمد ص 1.0

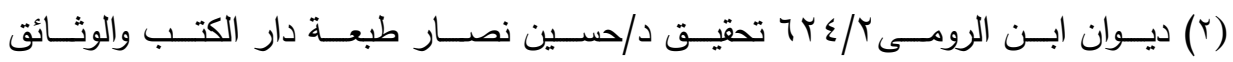


الاغتراب بين أبى فراس والمعتمد بن عباد - دراسة وموازنة - ماسل

عن الغزلان والأسود والجمال القصور ، وكأنه يسترجع فى مخيلته هذا العز الزائل

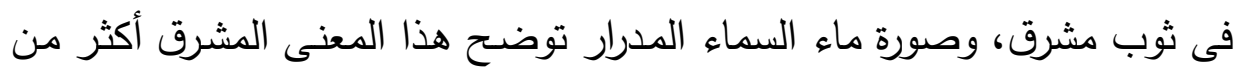
إيضاحها لكثرة البكاء.

وقد كان إحساسه بالاغتراب واضحاً فنراه يأسى على حياة زائله فقد صيرت

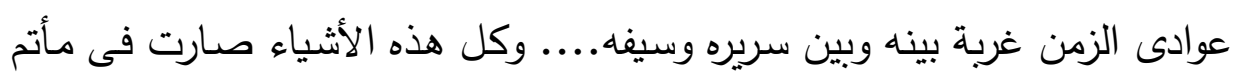
لفراق المعتمد يقول:

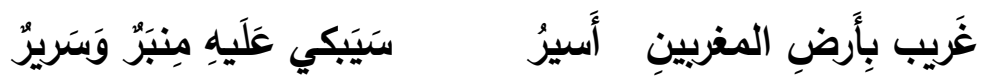

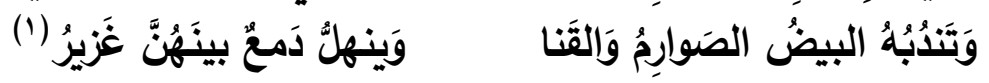
ويعطينا مفارقة بين الماضى والحاضر فيى العيد فيقول:

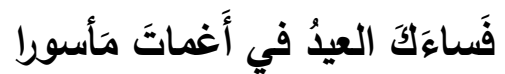

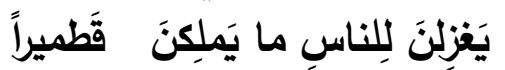

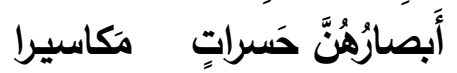

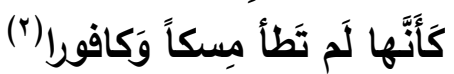

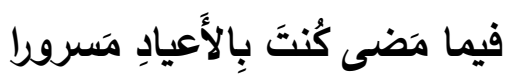
تَرى بَناتلكَ في الأَطمارِ جـائِعَةً

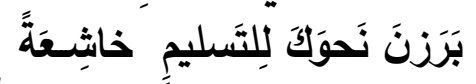

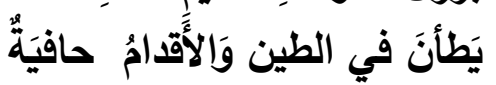

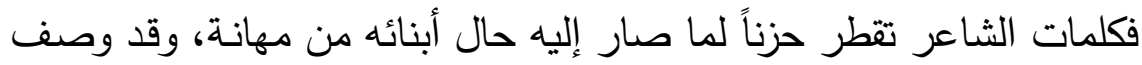

القيود فى أكثر من موضع فقال:

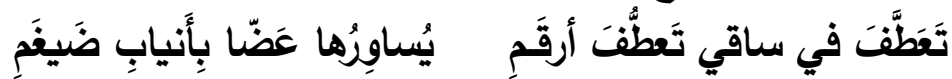

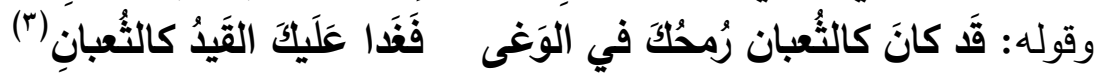

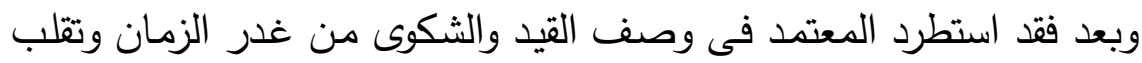

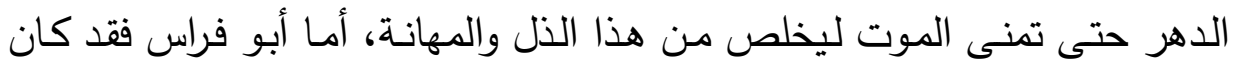
أقل تصويراً لمواطن الضعف التى يمر بها الأسير أو يشعر بها المغترب. رابعاً: الاستخ التحاد الادير

$$
\text { أ. عند أبى فراس. }
$$

لعل من أهم مظاهر شعر الأسر تعبيره عن رغبته فى أن يمد إليه ملكه يد

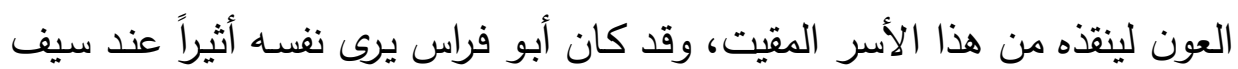

$$
\begin{aligned}
& \text { (1) ديوان المعتمد ص } 90
\end{aligned}
$$

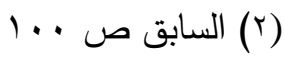

$$
\begin{aligned}
& \text { (r) السابق ص 11111 }
\end{aligned}
$$


الاغتراب بين أبى فراس والمعتمد بن عباد - دراسة وموازنة

الدولة، محبباً إلى قلبه لما بينهما من عصب ونسب وقوة لسلطانه، فقد كان قاهراً

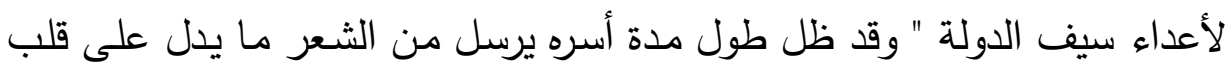

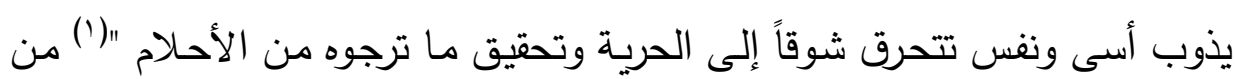

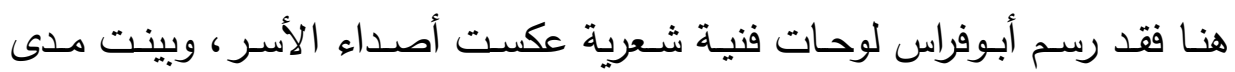

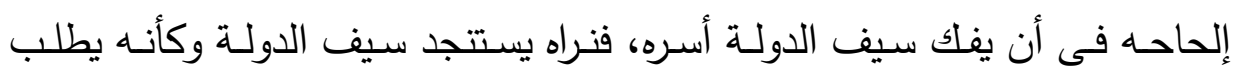

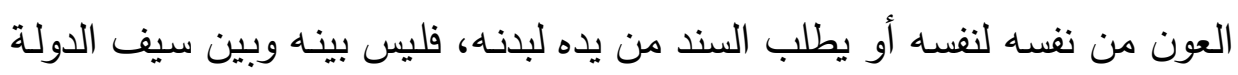
فوارق، فيقول:

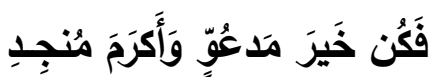

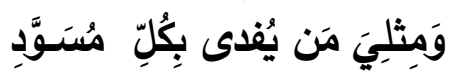

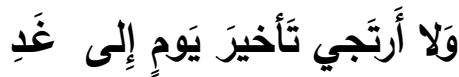

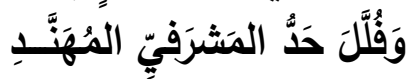

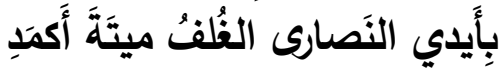
وَلا تَقَطَعِ التَسَآلَ عَنِّي وَتَقَعُدِ

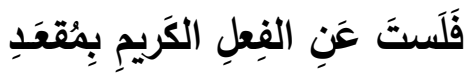

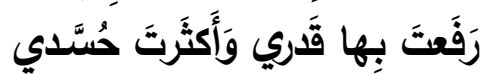

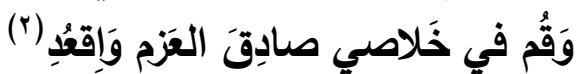

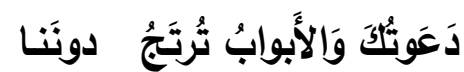

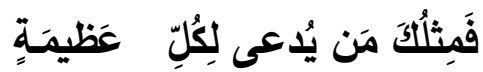

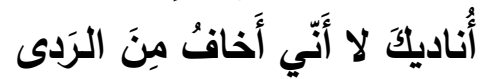

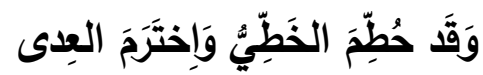

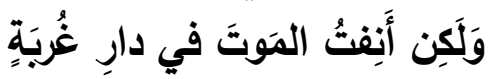

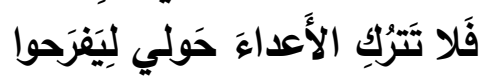

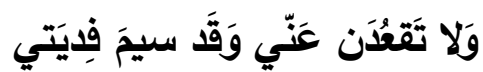

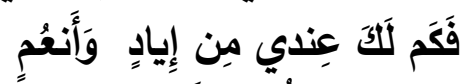

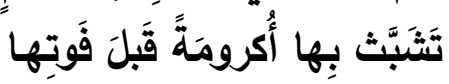

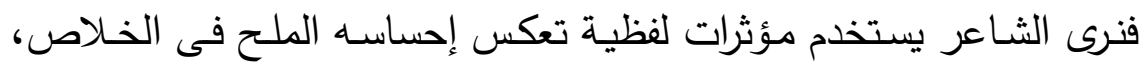

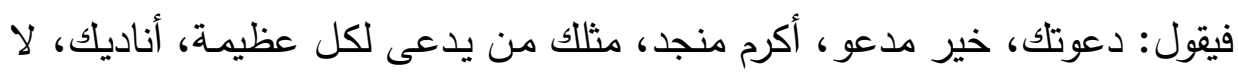

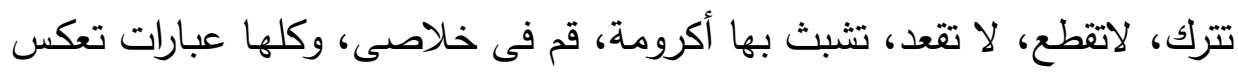

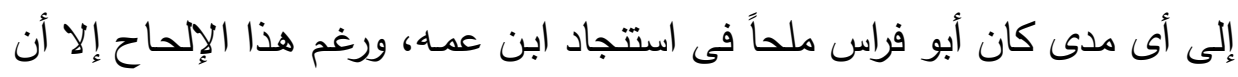

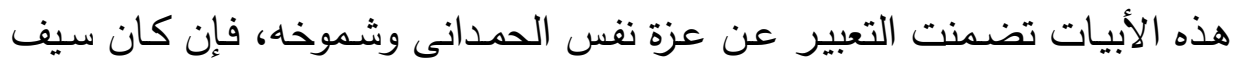
الدولة خير من يدعى لكل عظيمة فإن أبا فراس خير من يفدى بكل بكل مسود.

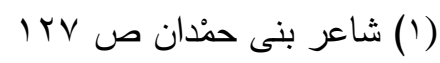

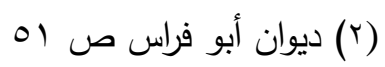


الاغتراب بين أبى فراس والمعتمد بن عباد - دراسة وموازنة

ويتقدم أبو فراس خطوة فى الإلحاح فى طلب النجدة مستعيناً باستـعاء

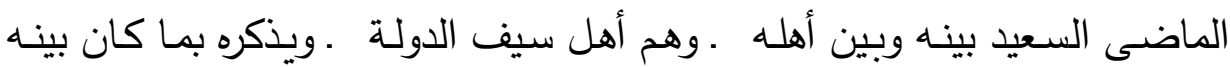
وبينهم من علاقات حميمة ومودة وبأس وشجاعة فى دفاعه عن ملك بنى حمد اهدان:

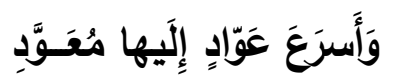

فَتَيَ غَيَرَ مَردودِ اللِسانِ أَوِ الَيَدِ

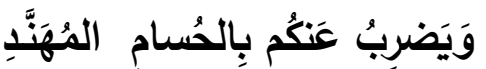

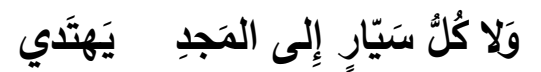

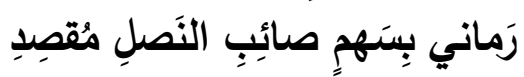

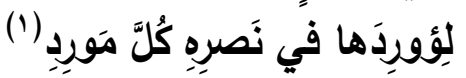

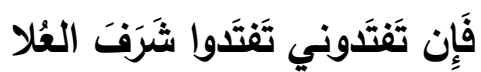

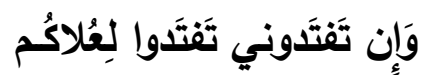

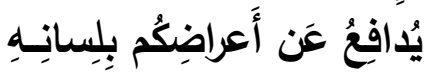

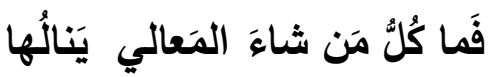

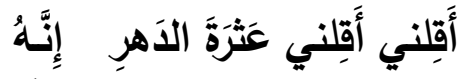

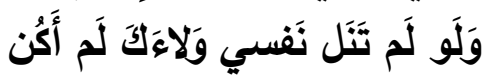

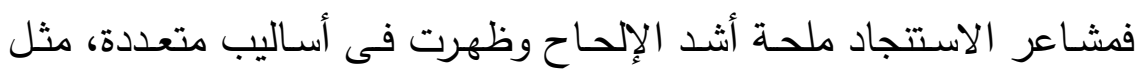
تفتدونى، تفتدوا، ثم إنه يبين ملامح تفرده حين يدافع عن قومه بيده وبلسانه، وتبلغ الإسن صراحته فى طلب النجدة إلى منتهاها حين يقول مستخدما أسلوب الكناية:

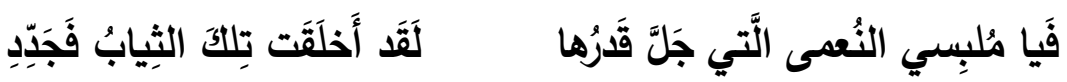

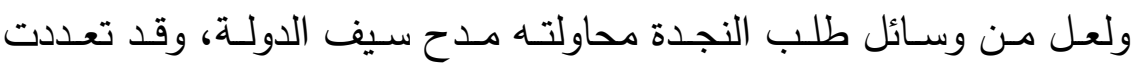
القصائد التى تتضمن الإشـارة لبطولته، ومدح سيف الدولة ليس فيـه مذلة لأبسى

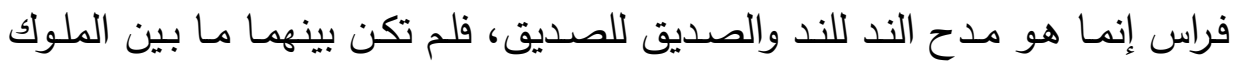
والشعراء من هبات وعطايا ترخص فيها همـة الشـاعر، لذا رأينا هذا المدح أشبه بالفخر، فهو يفتخر بابن عمه أكثر من كونه يمدح ملك فئك فيقول:

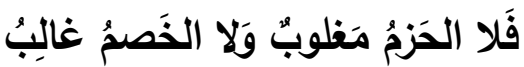

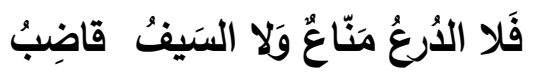

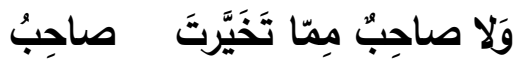

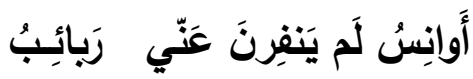

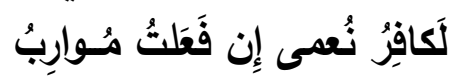

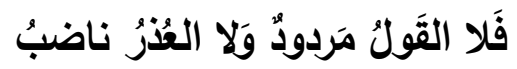

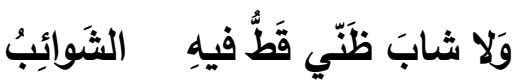

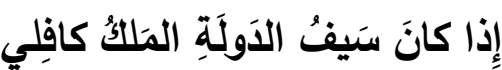

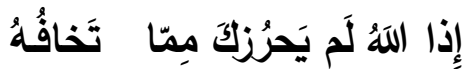

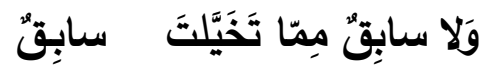

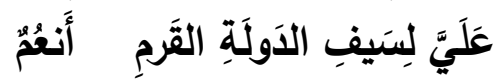

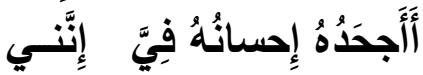
لَعَلَّ القَوافِي عُقَنَ عَمَّا لَََرَدتُهُ

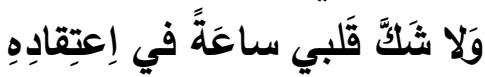


الاغتراب بين أبى فراس والمعتمد بن عباد - دراسة وموازنة

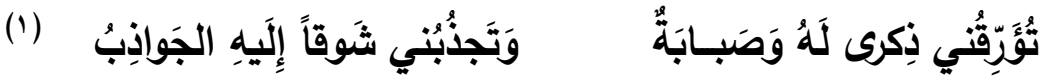
فهذا مدح ولكنه ليس كمدح الشعراء، واستعطاف ليس كاستعطاف المتذللين فأين هذا من النابغة ؟حين رأى النعمان قوة قدرية تلاحقه أينما حل فقال:

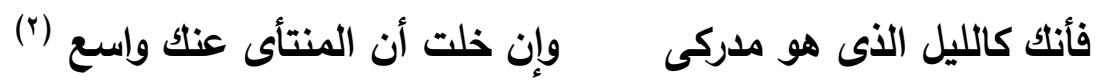
لكن أبا فراس يخاطب سيف الدولة فى شموخ وكبرياء. وروميات الحمدانى فيها كثير من المرارة، فقد تتبدى هذه المرارة فى رثائهـ لأبى المكارم ابن سيف الدولة، فيقول:

حَتّى عَنْ إِبنِكََ تُعطى الصَبَرَ ياجَبَلُ

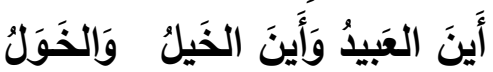

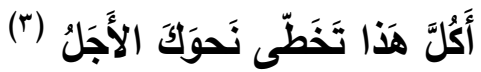

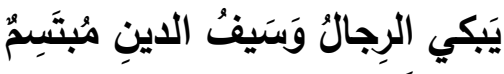

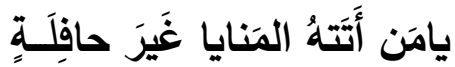

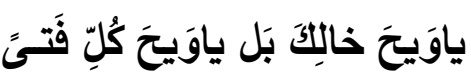

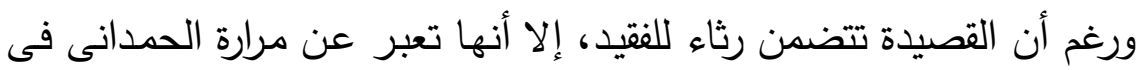

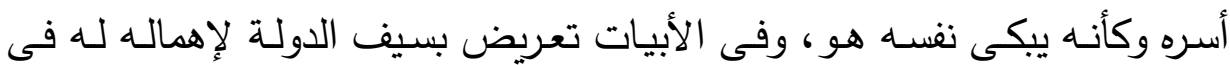
الأسر ، وقد تكرر هذا المعنى كثيراً فى رومياته، فيقول:

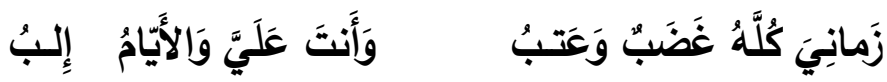

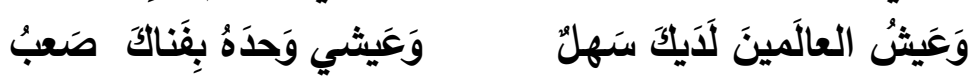

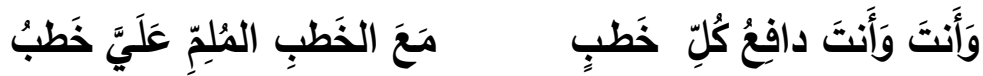

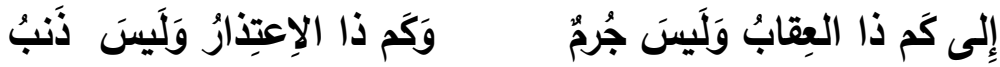

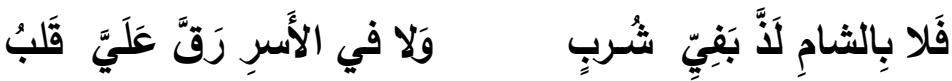

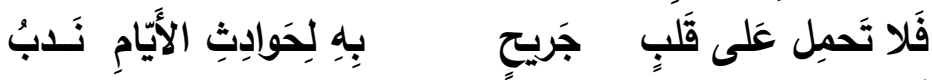

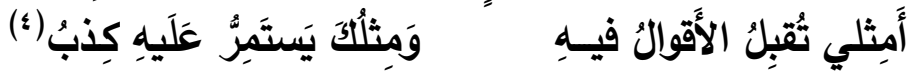
ونفس أبى فراس تقطر دما حين يقول هذه الكلمات فقد اشتدات كرة الأيام عليه وكأن كل عناصـر الكون أخذت تصب جـام غضبـها عليه، ولعل مما زاد

$$
\begin{aligned}
& \text { (1) السابق ص (1) } \\
& \text { (r) ديوان النابغة ص (r) }
\end{aligned}
$$

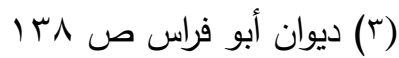

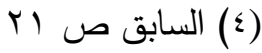


الاغتراب بين أبى فراس والمعتمد بن عباد - دراسة وموازنة - مرك

حزنه كثرة الوشاة به عند سيف الدولة، وربما أدرك أبو فراس بفراسته مايدور فى

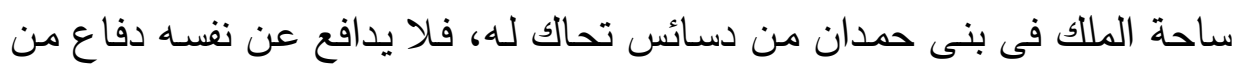

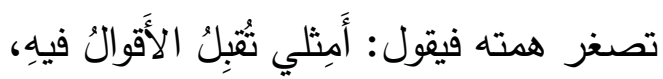
ونراه يلوم أصحابه الذين نسوه بعدما طالت مدة أسره فيقول:

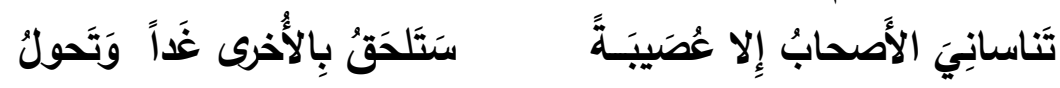

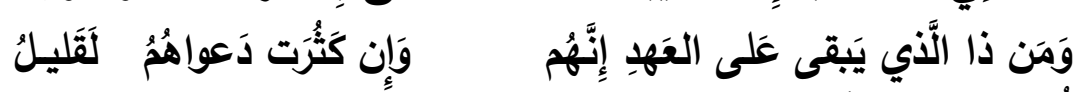

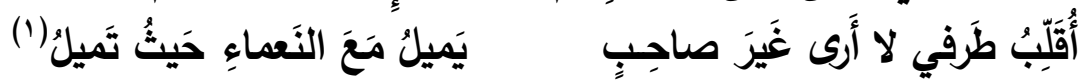

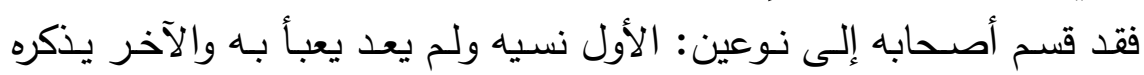

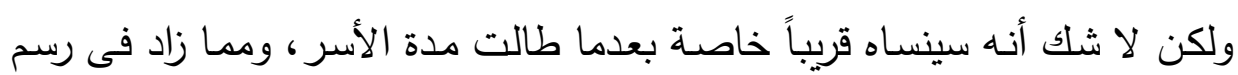
مـرارة الثـاعر أنـه جعل العصبة التى تـكره (عصيبة) موظفاً التصـغير كوسيلة تعبيرية تكشف عن شعوره الحزين وقلة من يذكرونه.

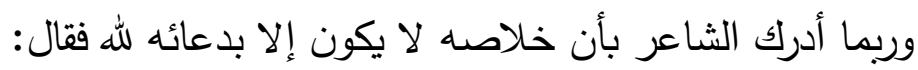

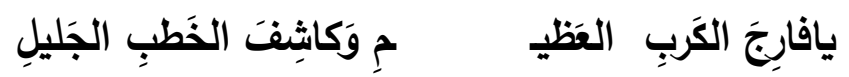

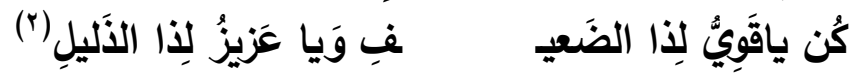

وهكذا نلاحظ أن أبا فراس كان دائمَ الإلحاح فى استجاد سيف الدولة، دائم اللوم لتقاعسه عن نجدته وفلك أسره.

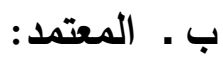

لعل مشـاعر المعتمد بن عباد كانت مختلفة كثيراً عن مشاعر أبى فراس،

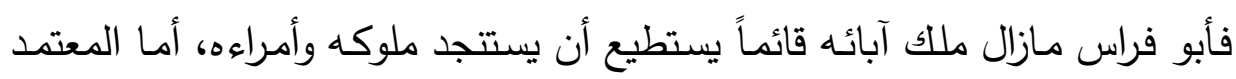

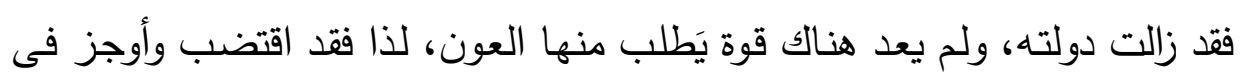
عرض هذا المعنى فلا نرى لله سوى قصيدة واحدة يدعو فيها الله تعالى أن يفرج كربه فيقول:

ما خابَ مَن يَثَكو إِلى الَرحمنِ

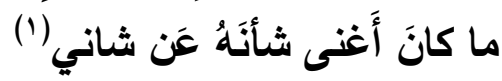

قَّلبي إِلى الرَحمنِ يَثَكو بَتَّهُ

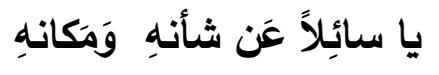

$$
\begin{aligned}
& \text { (1) السابق ص }
\end{aligned}
$$

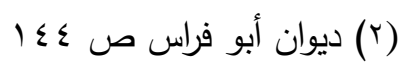


الاغتراب بين أبى فراس والمعتمد بن عباد - دراسة وموازنة -

وهكذا نـرى أبـا فـراس نـوع فـى هذه الظـاهرة وأفـاض فـى عـرض جزئيـات

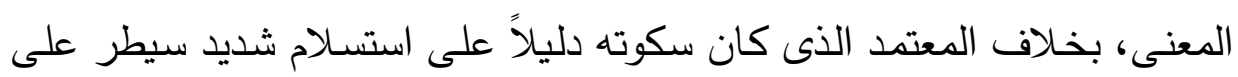

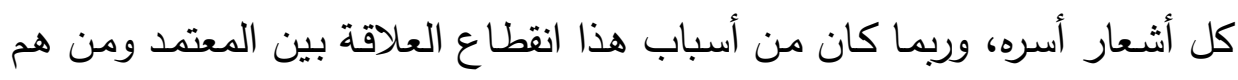

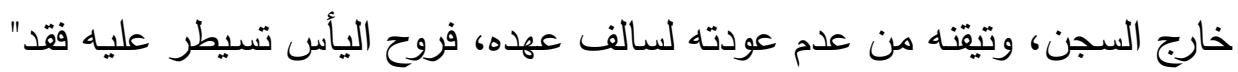

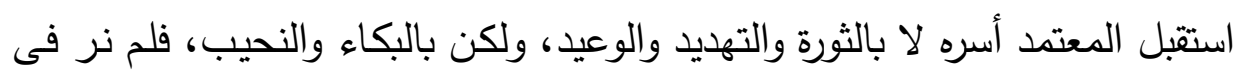

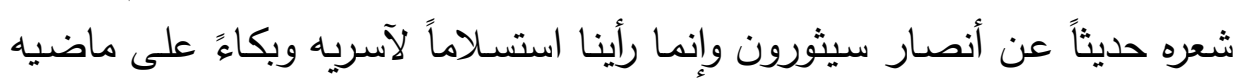


الاغتراب بين أبى فراس والمعتمد بن عباد - دراسة وموازنة

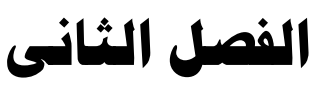

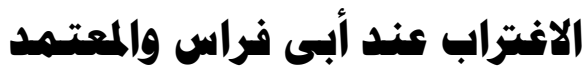

روئة فنية

أولاً: الألفاظ والأساليب

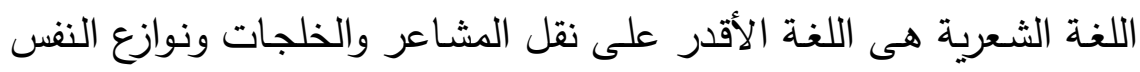

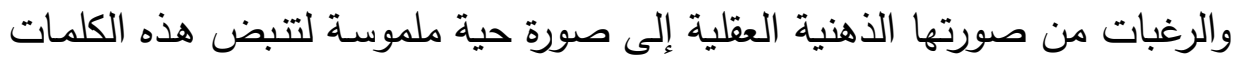
فى نفس المتلقى بمثل ما وهجت به هذه المشاعر فى نفس مبدعها. واللغة تتسم ببراعتها فى التعبير عن هذه غموض به المشاعر ، والشاعر المديز

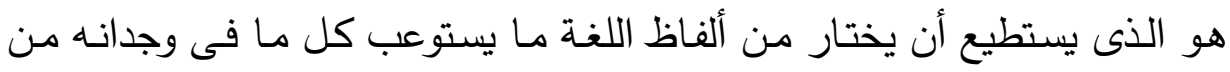

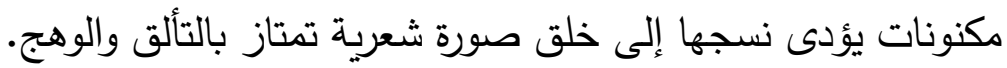

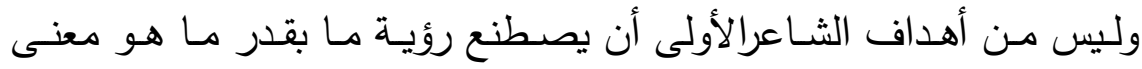

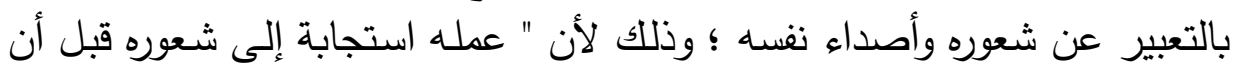

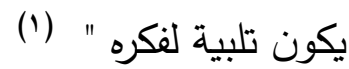

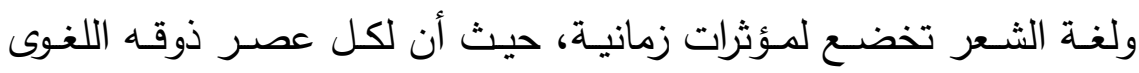

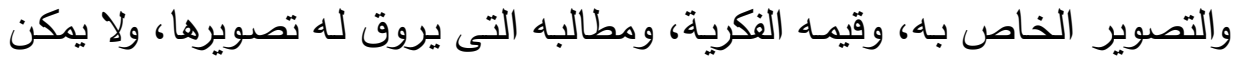

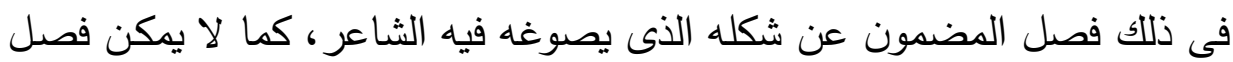

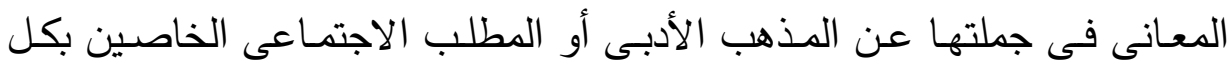

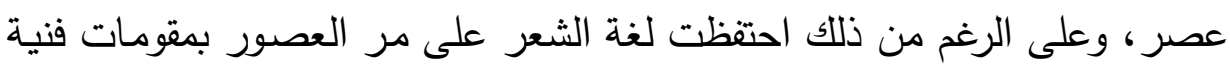
لازالت تتمو بفضل عباقرة الشعراء والنقاد فى مختلفى الآداب، وانتهت إلى العى العصر

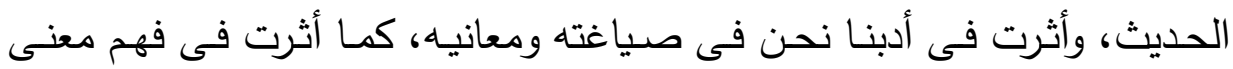

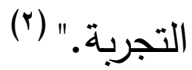

وسوف نبين ملامح الشاعرية فى لغة شاعرينا فى شعر الاغتراب عندهما:

$$
\text { أ ـ أبو فراس في في }
$$

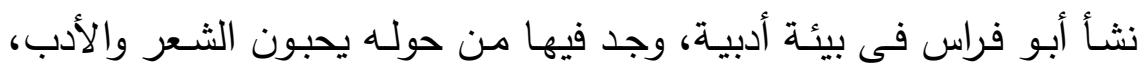

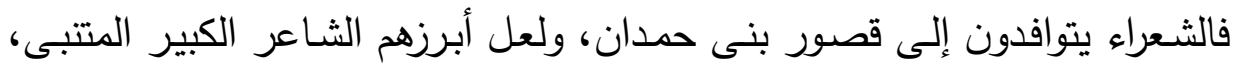

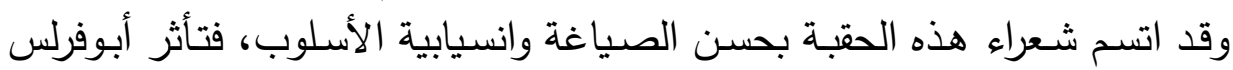

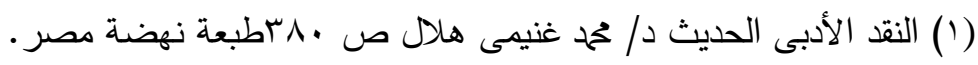

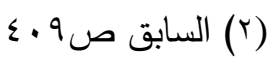


الاغتراب بين أبى فراس والمعتمد بن عباد - دراسة وموازنة

بهذا الأسـلوب الأدبـى فتشكلت لديـه شـاعرية تتسـم بسـهولة الأسـلوب وانسـيابية

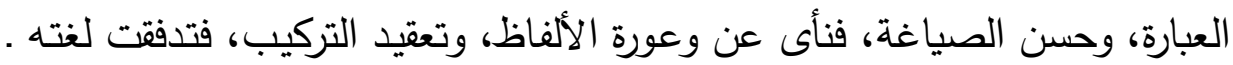

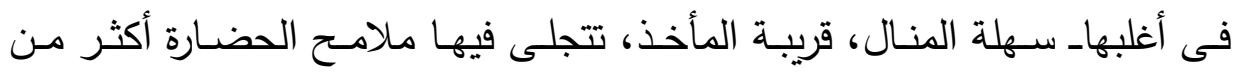

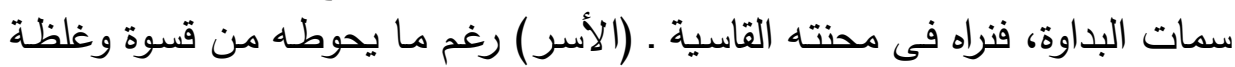
مادية ومعنوية ـ يعبر عن آلامه في سهولة فيقاه فيقول:

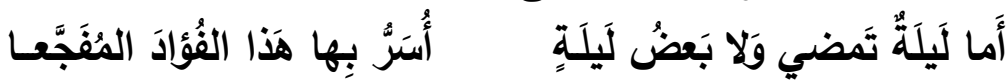

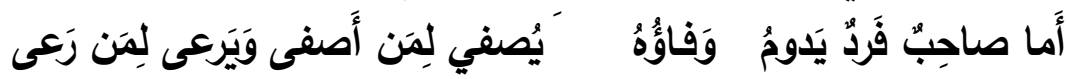

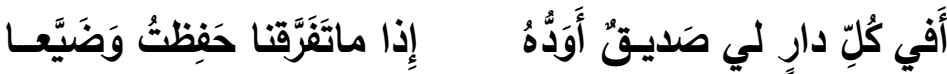

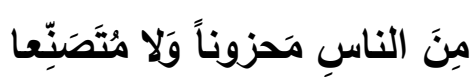

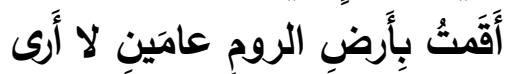

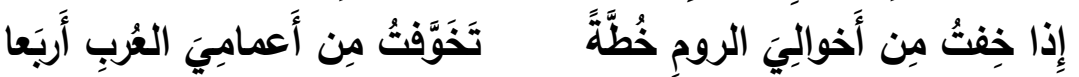

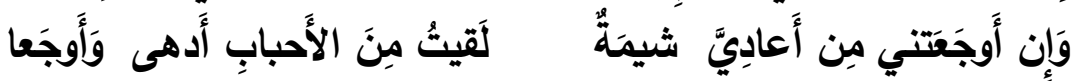

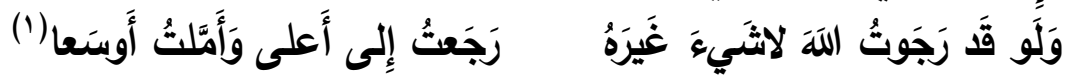

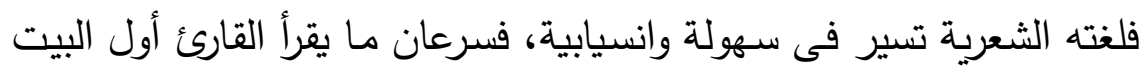

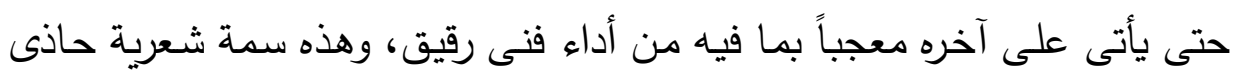

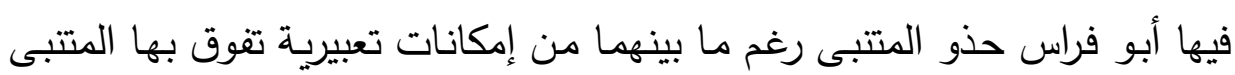
على شعراء العرب. ولو شئنا دليلاً على هذا التأثر لرجعنـا إلى قصيدة المتنبى الذى يمثل مطلعها براعة الصياغة الفنية حين يقول:

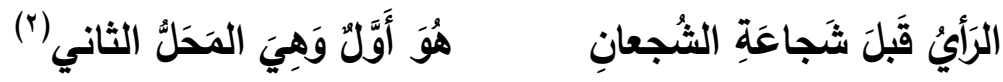

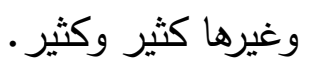

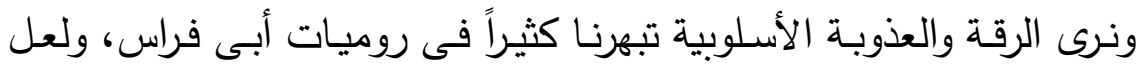
قصيدته الشهير أراك عصى الدمع خير دليل على هذه السهولة يقول فيها:

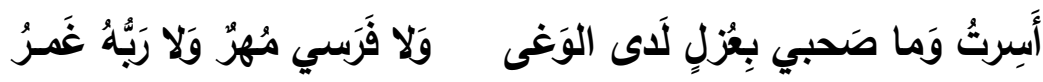

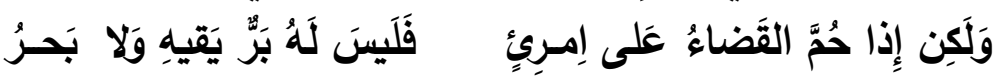




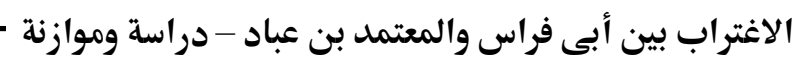

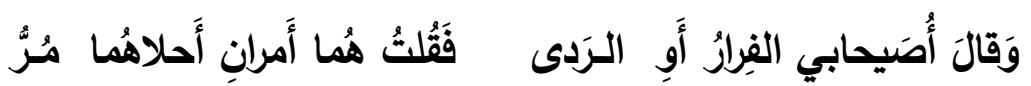

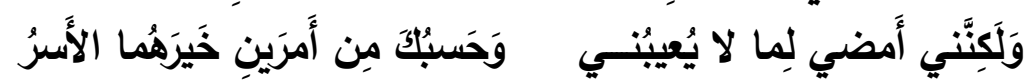

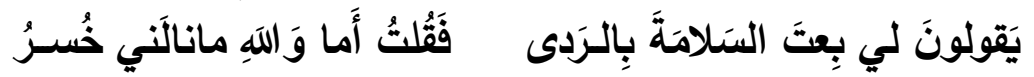

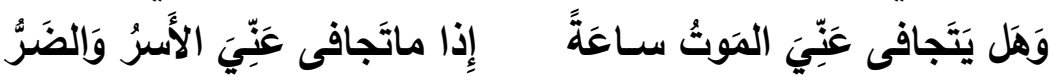

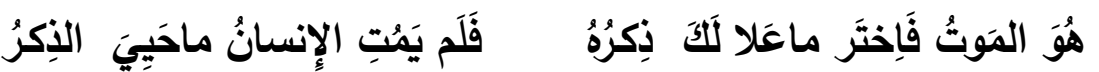

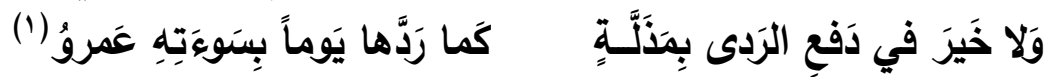

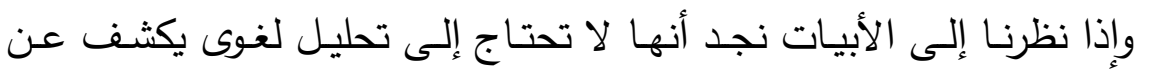

مدلول الألفاظ، ورغم وضوحها فهى تفيض عن آخرها بقيم لفظية فنية متتوعة مثل إنل

حسن الاختيار وتموجات المقابلات التى جاءت مطبوعة وسوف يتضح ذللك بعد.

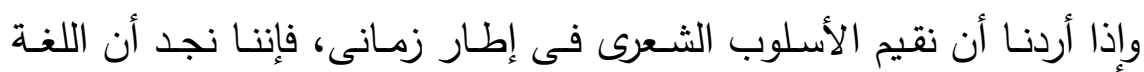
التى استخدمها أبو فراس شديدة الوضوح لأهل القرن الثالث الهجرى، فعلى الرغم التهم

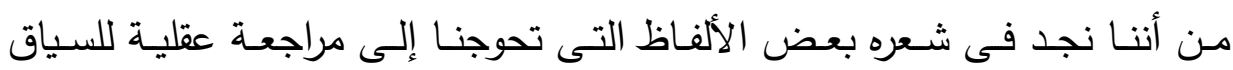

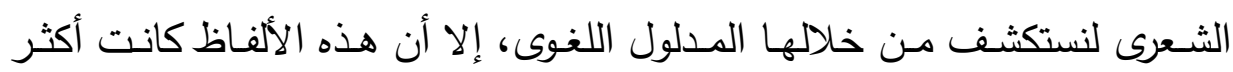

وضوحاً للجمع الأدبى والعامى لأهل القرن الثالث الهجرى فنراه يقول:

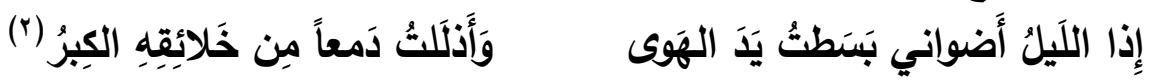

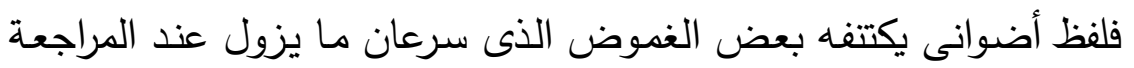

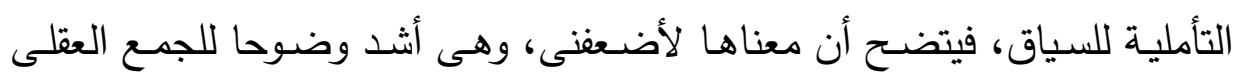
لأهل القرن الثالث الهجرى، ومن ذلأك أيضاً قوله فى مقدمته الغزلية:

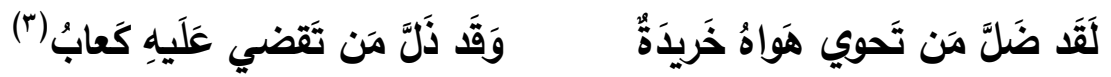

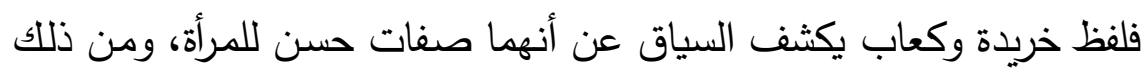

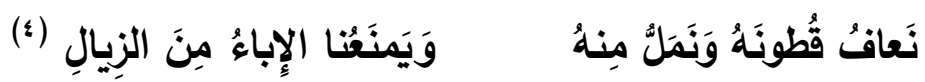
أيضا قوله:

$$
\begin{aligned}
& \text { (1) ديوان أبو فراس ص } 77
\end{aligned}
$$

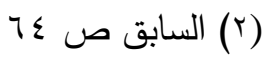

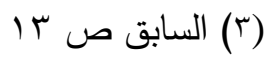

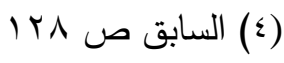


الاغتراب بين أبى فراس والمعتمد بن عباد - دراسة وموازنة

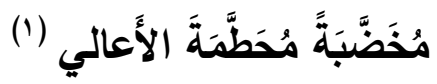

وقوله فى نفس القصيدة:

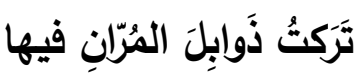

\section{وقوله:}

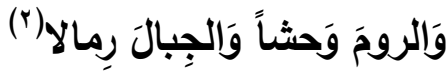

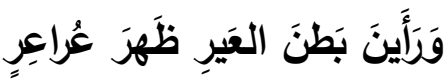

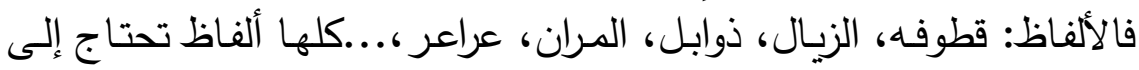

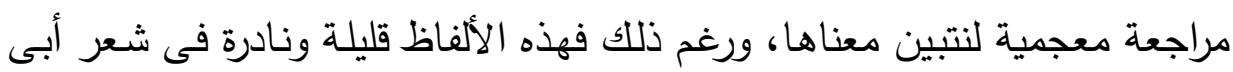
فراس.

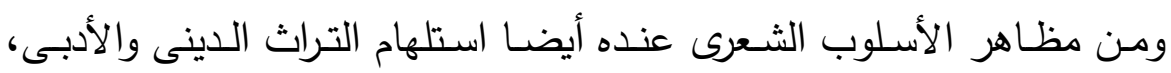

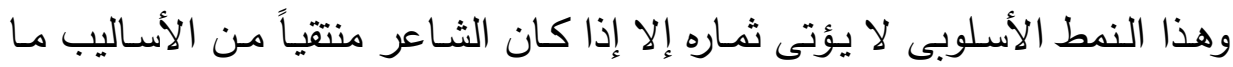

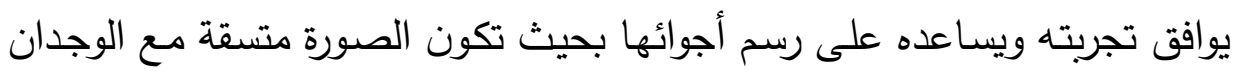

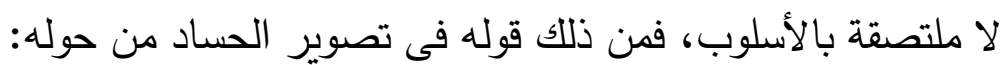

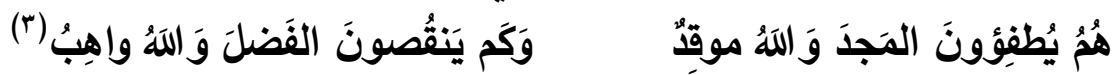

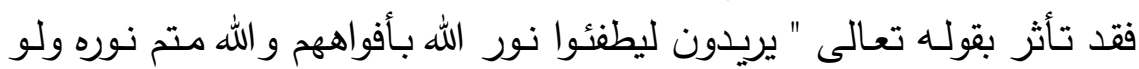

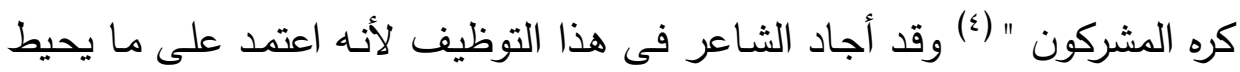

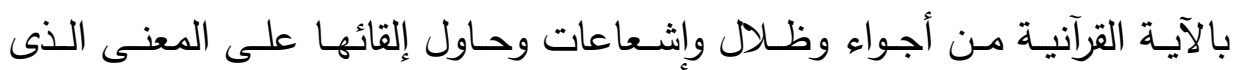

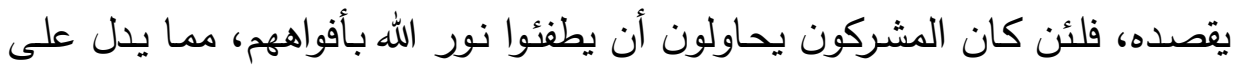

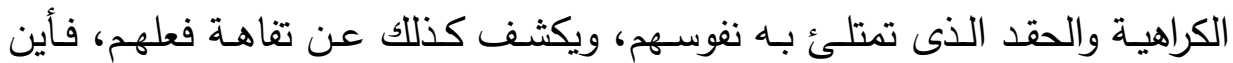

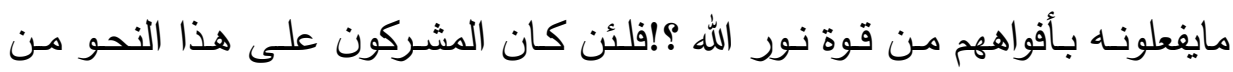

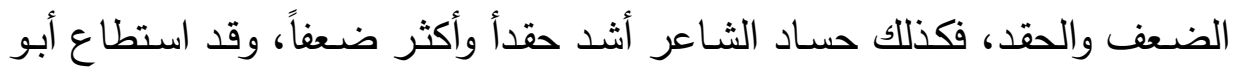

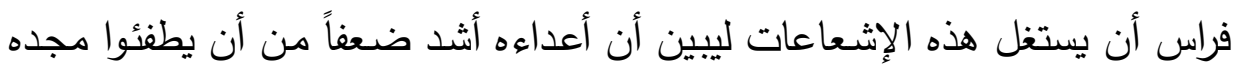
الأثيل.

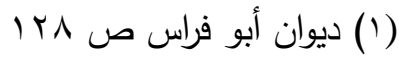

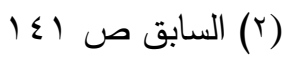

r

(^) سورة الصف آية(^) 
الاغتراب بين أبى فراس والمعتمد بن عباد - دراسة وموازنة

ورغم هذه الجودة فى الاقتباس من القرآن الكريم إلا أن أنه كان قليلاً فى

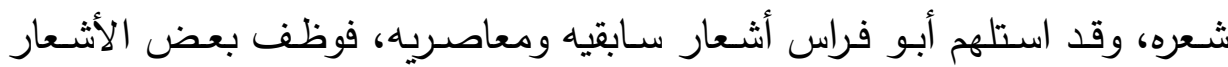
التى جاءت فى أشعارهم، من ذلك قوله وقد أقبل العيد وهو في الأسر :

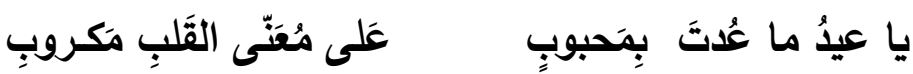

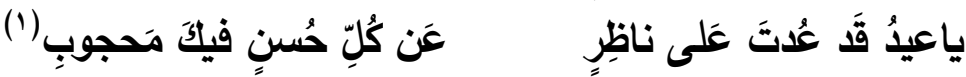

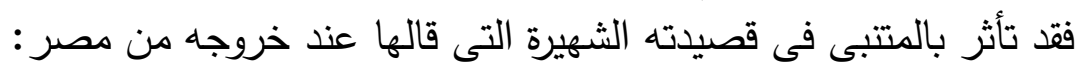

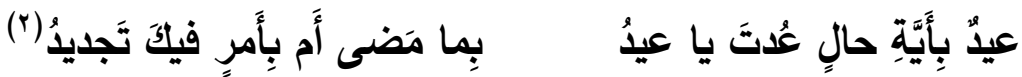

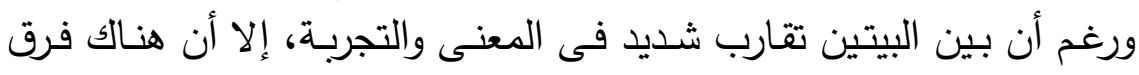

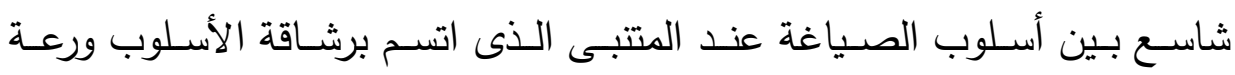
التركيب والتصوير فقد رسم لنا زفرة حارقة تتقد جذوتها فى نفس المتبهى، وقد زاد فى تأثيرها المفارقة البعيدة بين بهجة العيد وآلام الشاعر ، ثم إنه يكشف عن حئ حيرة ممزوجة بالأمل فى غد مشرق، وهذه هى مشاعر المتنبى وتجربته.

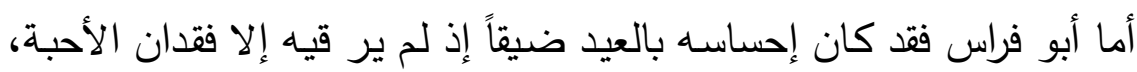

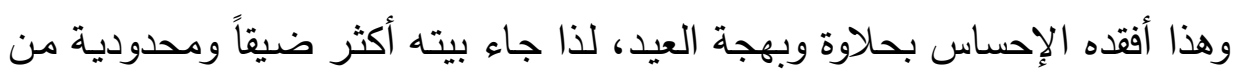

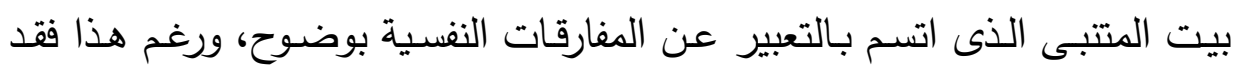
عبر الحمـدانى عن المعنى الذى فى نفسـه فى صـياغة مباشـرة، ولا يقلـل منهـا

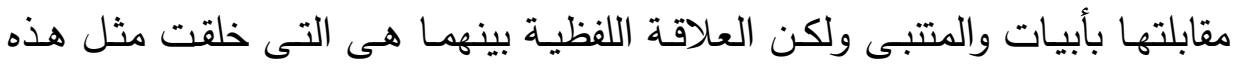
الموازنة.

وقد بدت ملامح التأثر بالقدماء فى قوله:

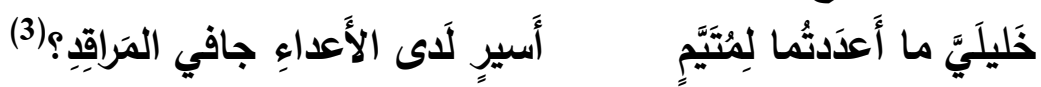

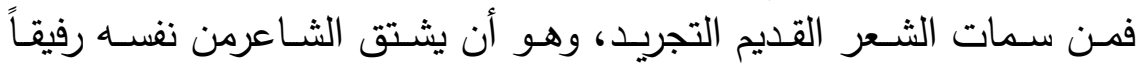

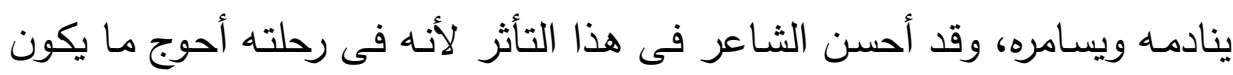
إلى رفيق يبثه أحزانه وأوجاعه.

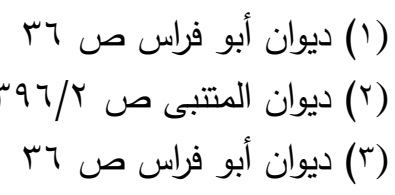


الاغتراب بين أبى فراس والمعتمد بن عباد - دراسة وموازنة

وقد قلد القدماء دون جدوى فنية حين رمز لمحبوبته باسم شائع عند القدماء:

كَأَنّي أُنادي دونَ مَيثاءَ ظَبَيَةً

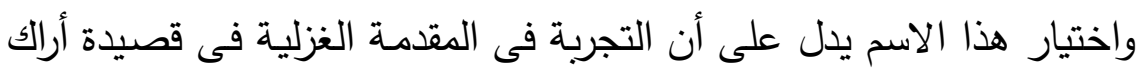

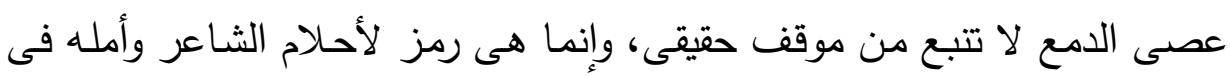

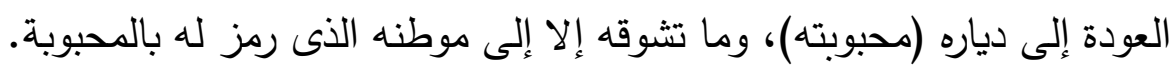

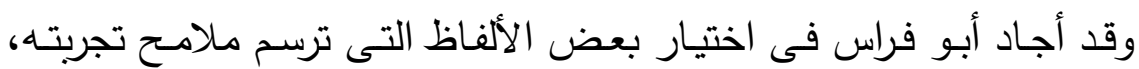

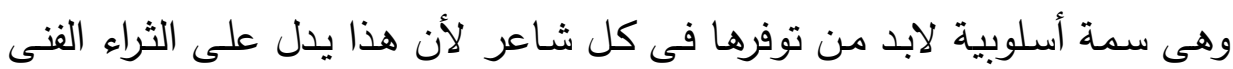

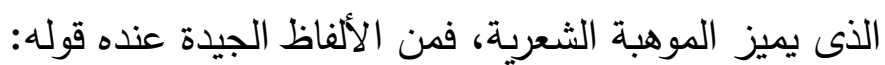

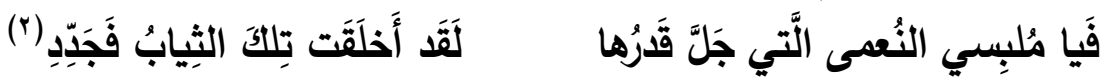
فلفظ (ملبسى) يدل على تجدد الفعل وهو يدل على نعم وآلاء سيف الدولة على الشاعر، ثم يتلو هذا اللفظ بالصورة المقابلة أخلقت ليبين الفرق الشاسع بين الحالتين، فاختيار اللفظ هنا فعـال فى رسم أجواء التجربـة، ونـراه لا يستخدم لفظـاً

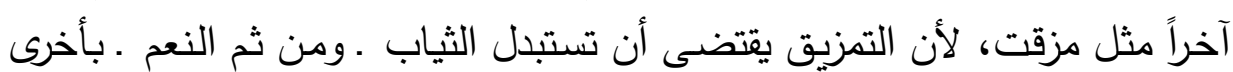

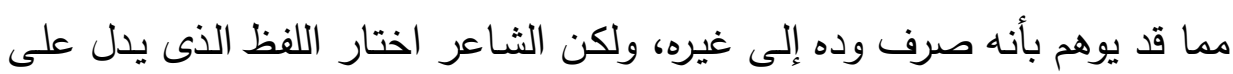

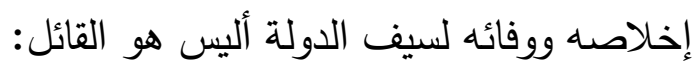

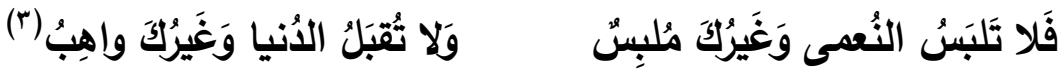

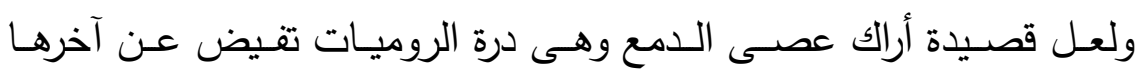

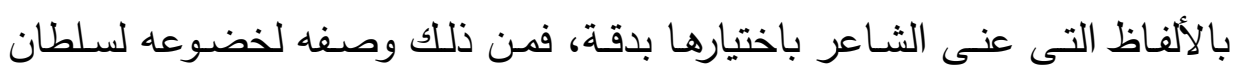

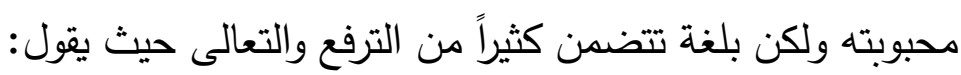

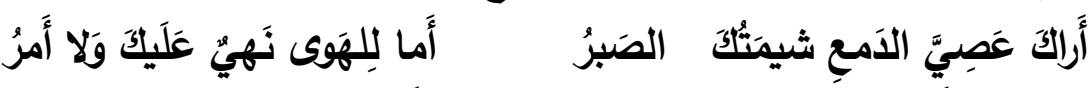

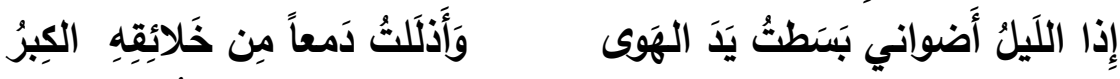

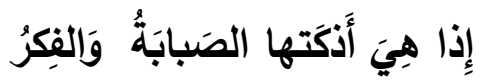

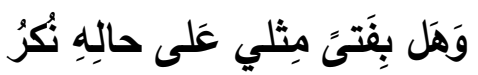
تَكادُ تُضيءُ النارُ بَينَ جَوانِحِي

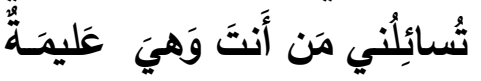

$$
\begin{aligned}
& \text { (1) السابق ص or } \\
& \text { (r) ديوان أبو فراس ص (r) } \\
& \text { r }
\end{aligned}
$$


الاغتراب بين أبى فراس والمعتمد بن عباد - دراسة وموازنة

\section{مُعَوَّدَةٍ أَنْ لايُخِلَّ بِها النَصـرُ}

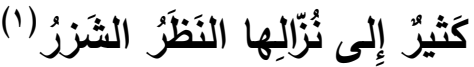

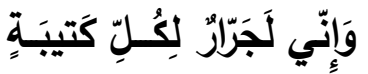

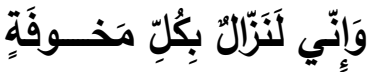

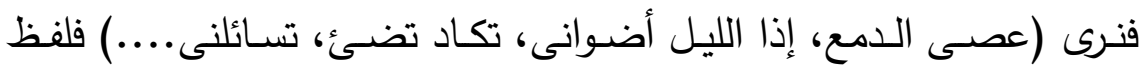

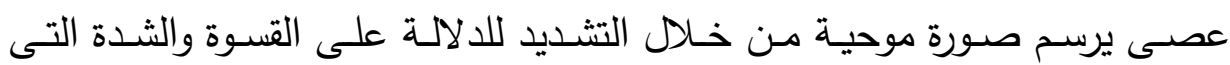

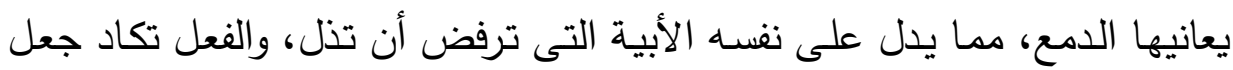

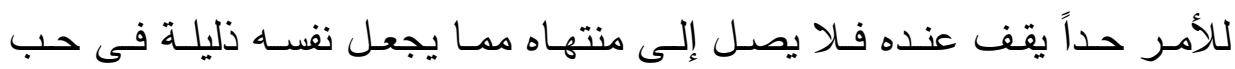
محبوبته، ودلالة لفط يضسئ يكشف عن منزلته فى قومـه فهو ضوء يهدى وليست

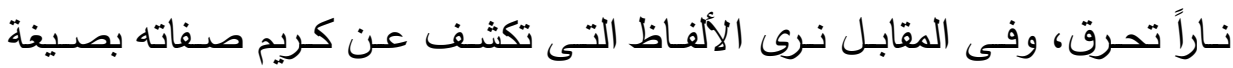
المبالغة، وهى متعددة مما يدل على الثبوت والدوام والمبالغة فى الفعل، فنرى (إنى التى

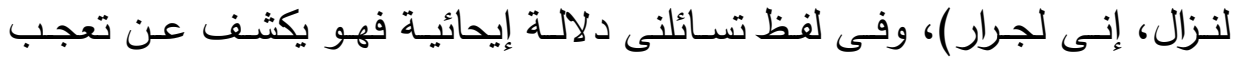
الشاعر من هذه المحبوبة (الرمز) التى تسأله عن اسمه، وهو سؤال ولكن الثـاعر جعله تساؤلا ليكشف عن تعجبه من هذه المحبوبة مما يعكس مرارته لنسيانه فى الأسر وأنه قد صار نسياً منسيا.

ثم نرى الإيحاء الإيقاعى حين يقول:(الليلة الظلمـاء) فإيقاع الظلمـاء رسم

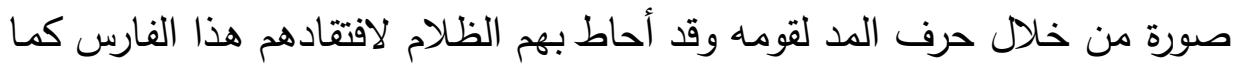
يفتقد البدر فى الليلة الظلماء، هذا فضـلا عن تميّزه فى توظيف الفعل المضـارع

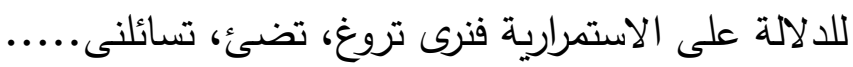
هذه هى أهم سمات الألفاظ عند شاعرنا. ب ـ المعتمد.

إذا كنا قد لاحظنا سهولة الأسلوب عند أبى فراس فإن المعتمد كان أكثر

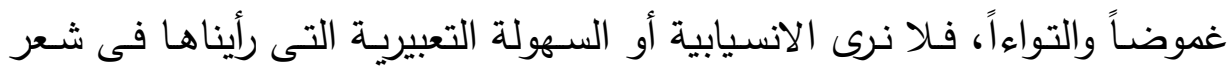
الحمدانى، فقد مال إلى استعمال الألفاظ الغرببة التى تحوجنا إلى مراجعة المعاجم ففى قصيدته إلى شاعره الدانى التى يشكو فيها جور الزمان، يقول:

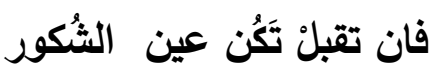

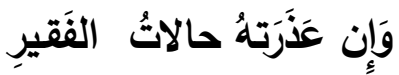

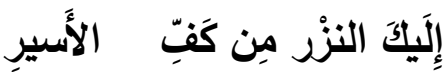

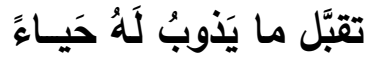


الاغتراب بين أبى فراس والمعتمد بن عباد - دراسة وموازنة

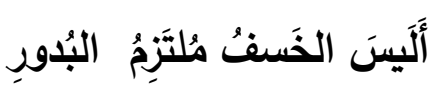

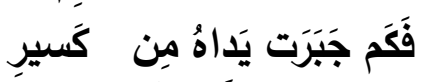

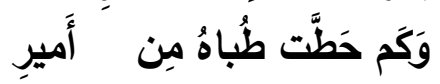

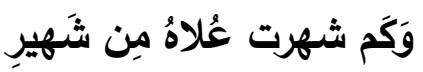

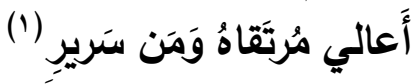

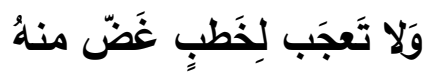

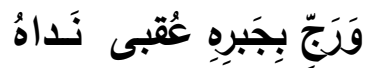

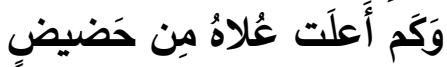

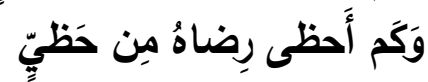

وَكَم مِن مِنِبَرٍ حَنّت إِلَيـهِ

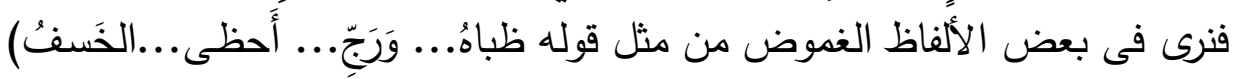

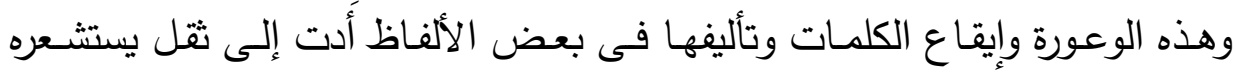
القارئ لهذه الأبيات.

وقد كان من سمات الشعر فالأندلس تأثثه الثديد بشعراء المشرق، " إن هذا

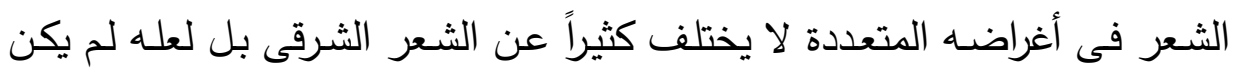

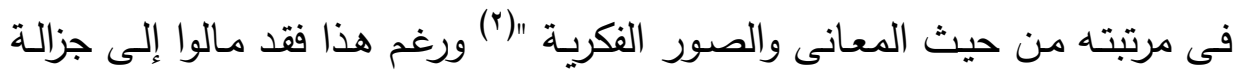
اللفظومتانته، وربما كان السبب فى هذ التأثر بالشرق وغلبة النزعة العربية على هلى نفس ملوك وحكام الأندلس.

ونرى المعتمد يصف الخـادم الذى صـرف ابن حميدس الثـاعر بعدما أراد

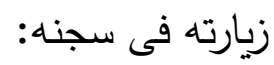

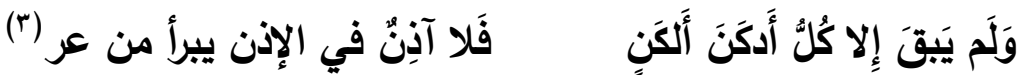

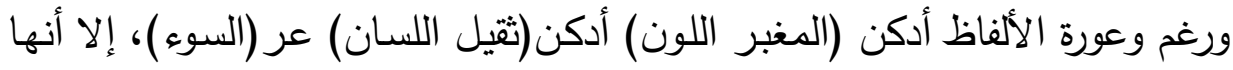

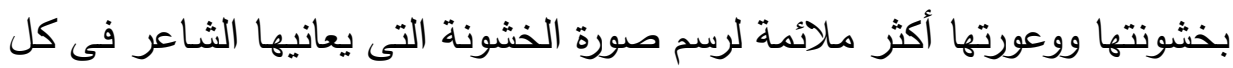
شئ حوله حتى فى ألفاظ شعره. ويمثل ظاهرة وعورة الألفاظ عند المعتمد قوله وقد وقد رأى سربا من الحمام:

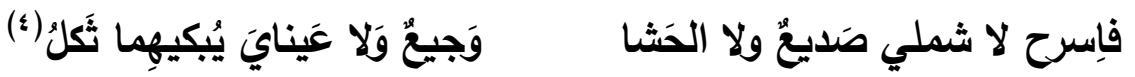

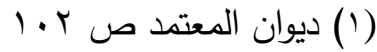

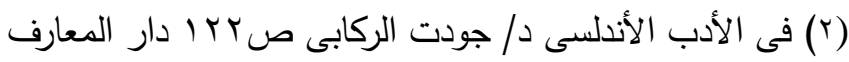

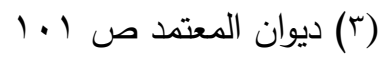

$$
\begin{aligned}
& \text { (؛) السابق ص (1) } 111
\end{aligned}
$$




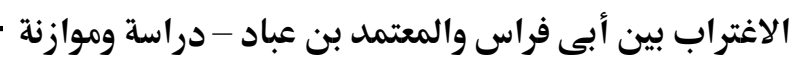

وربما أحس المعتمد وعورة ألفاظه فأراد أن يعطى البيت رشاقة تتبع من موسيقاه

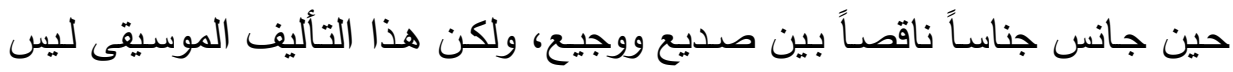

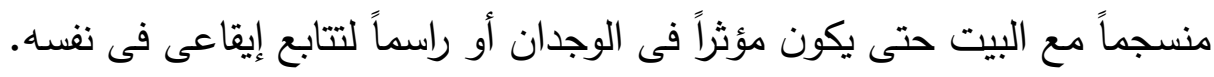

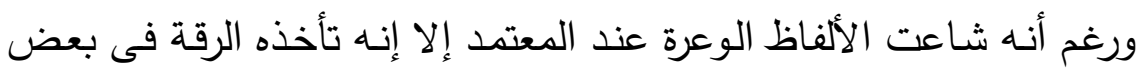

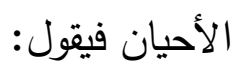

وَالثَُوكُ يَنْبُتُ فيِهِ الوَردُ والآسُ

فَقَََّما جَرحت إلإِنََّتَ تاسو
مَن يَصحَب الاَهر لَم يَعَدم تَقَلّبَهُ

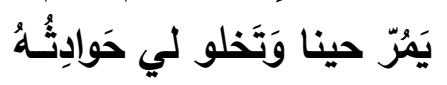

والتقليد للمشارقة كان سمة بارزة فى الشعر الأندلسى لذا رأينا المعتمد يميل إلى تقليد المشارقة فيقول:

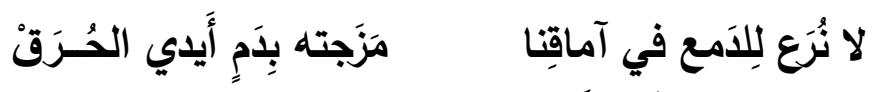

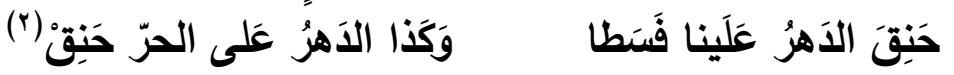

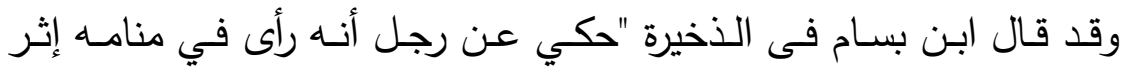

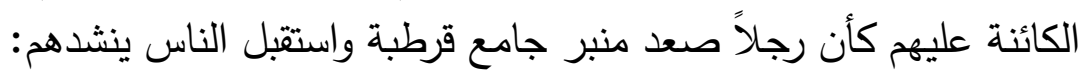

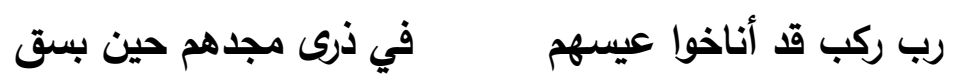

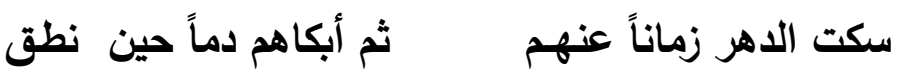

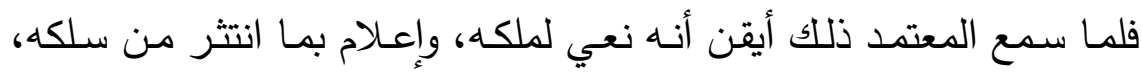
فقال:

من عزا المجد إلينا قد صدق لم يلم من قال مهما قال حق "(־)

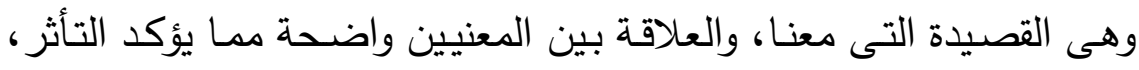

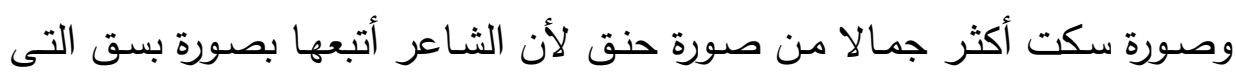
كشفت عن مفارقة شديدة بعيدة التأثير فى رسم شدة الحدث، ثم إن صورة المعتمد

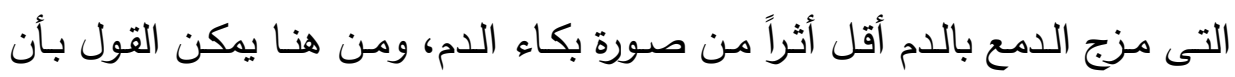

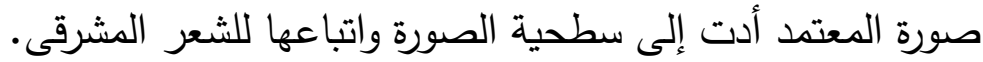

$$
\begin{aligned}
& \text { (1) ديوان المعتمد ص V. 1. 1. }
\end{aligned}
$$

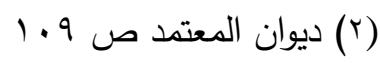

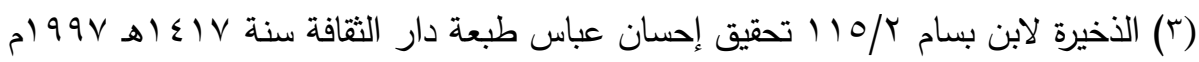


الاغتراب بين أبى فراس والمعتمد بن عباد - دراسة وموازنة -

أَمامي وَخَلَفي رَوضَةٌٌ وَغَديرُ (1)

$$
\text { ومن ملامح الاقتباس الشعرى عنده: }
$$

$$
\text { ومن أظهر صور الاقتباس الشعرى قوله: }
$$

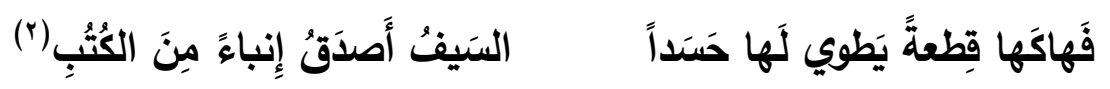

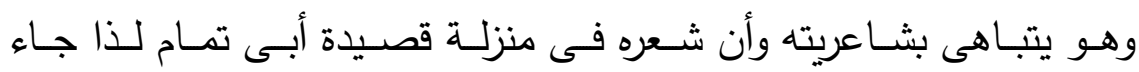
الاقتباس سطحياً ليس وراءه كبير معنى. وبذللك فإن اقتباسـات المعتمد لا ترقى لأن تكون إضـافة للتجربـة الثـعرية،

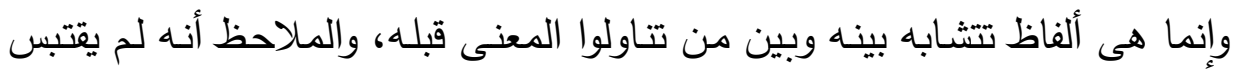
من القرآن الكريم وهذا يدلل على أنه لم يهتم بالصيغة الفنية للنص المقتبس.

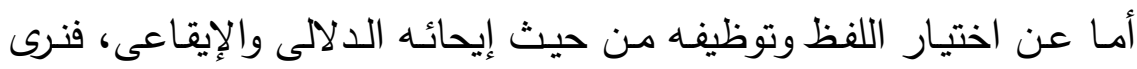

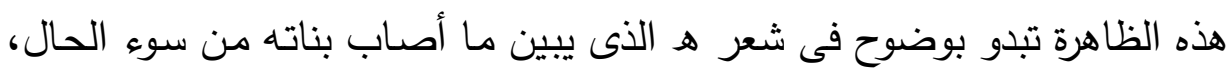
فنراه يستخدم جمع التكثير لبيان شدة البلوى، فيقول:

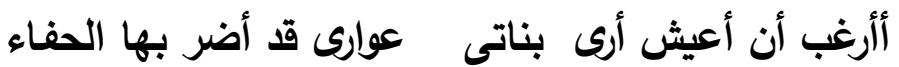

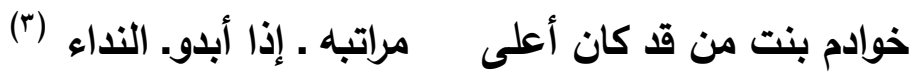
فصيغة فواعل (خوادم) دلت على عمق فى المعنى وإحساس شديد بالحزن. ونرى صورة القيد تتكرر بصورة مؤثرة ودالة فى قوله:

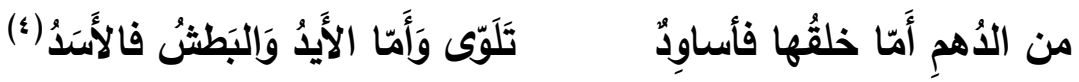

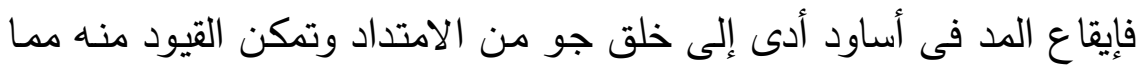
رسم صورة الألم بوضوح. وبعد فإن أبا فراس كان أميل إلى السليقة والطبع في معالجته للألفاظ من المعتمد الذى كان أكثر تقليداً للمشارقة.

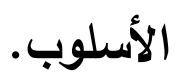

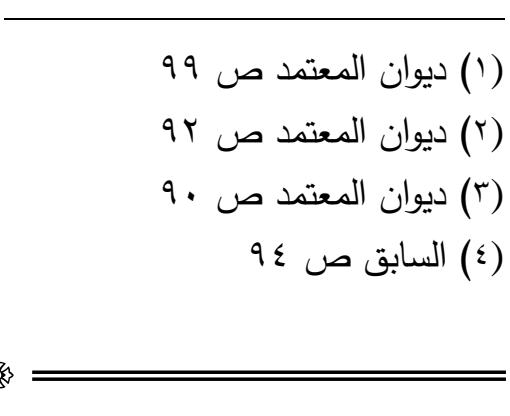


الاغتراب بين أبى فراس والمعتمد بن عباد - دراسة وموازنة

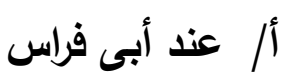

لعل من أبرز الأساليب الإنشائية التى استخدمها أبو فراس أسلوب الاستقهام

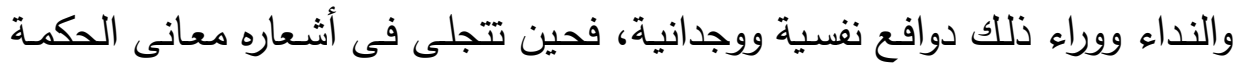

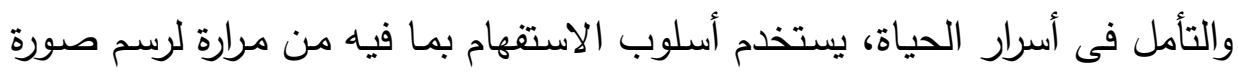

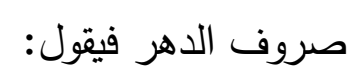

وَهَلَ يَعلَمُ الإنسانُ ماهُوْ كاسِبُ

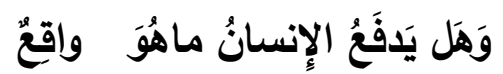

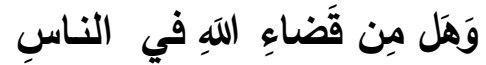

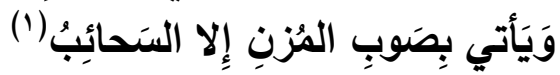

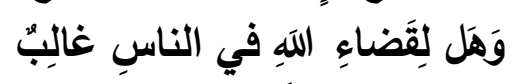

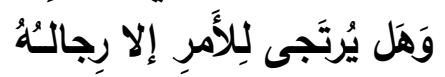

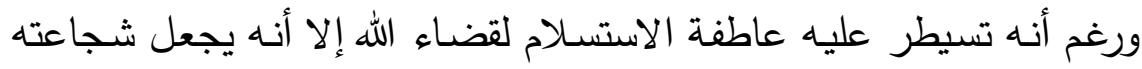
وبأسه فى الحرب من قرد الله أيضا وهذه محاولة للفخر أيضاً.

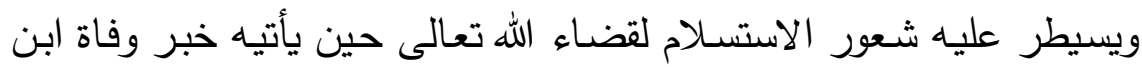

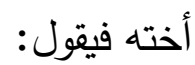

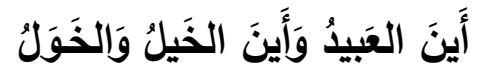

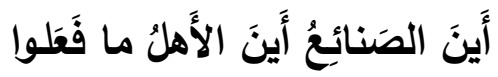

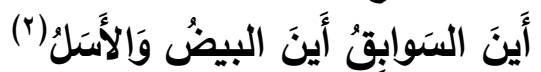

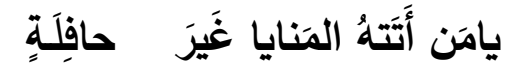

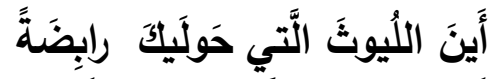

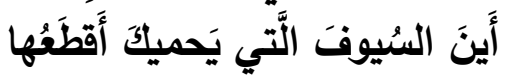

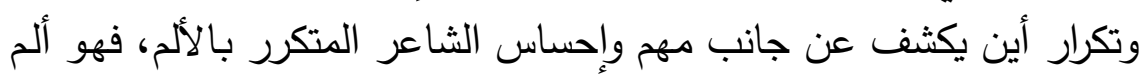

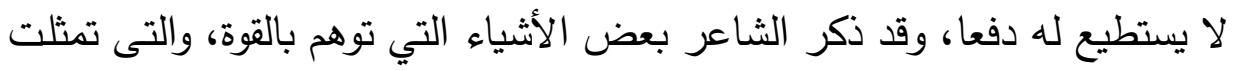

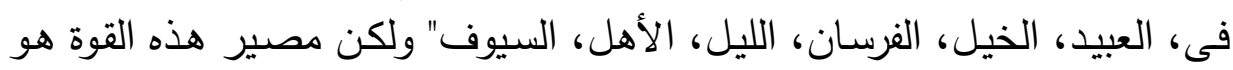
العجز والاستسلام، وتتأجج نفسه وإحساسه بالعجب من مفارقات الحات الحياة فيقول:

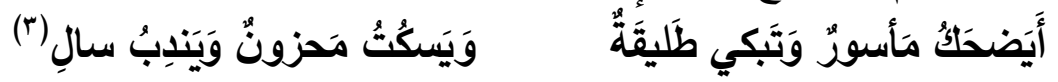

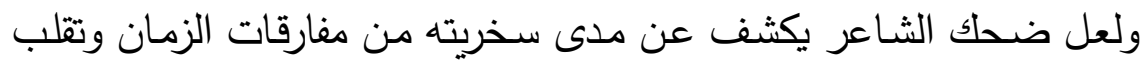

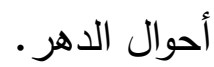

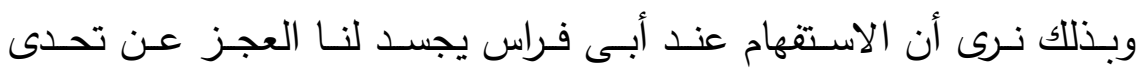

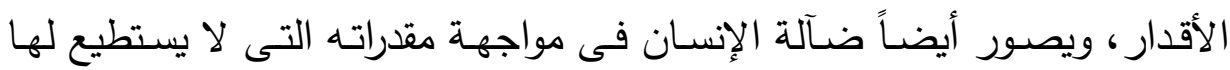

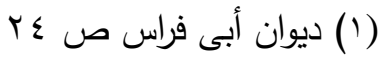

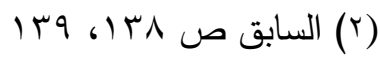

$$
\begin{aligned}
& \text { (r) السابق ص זr (r) }
\end{aligned}
$$


الاغتراب بين أبى فراس والمعتمد بن عباد - دراسة وموازنة

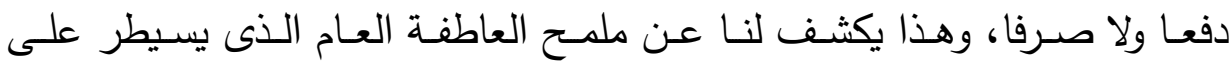

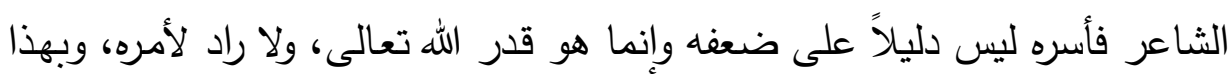
نرى أن الاستفهام وسيلة مؤثرة فى رسم أجواء التجربة الشعرية عند فئ أبى فراس.

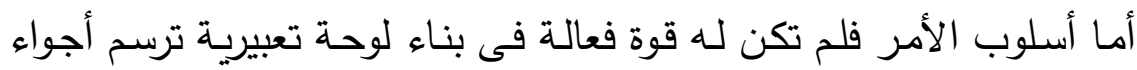
التجربة ؛ وذلك لأنه اعتمد على فكرة واحدة وهى طلب الغوث والنجدة، فانحصرت الرؤية التعبيرية فى هذا المعنى دون سواه فيقول:

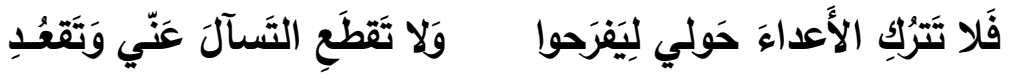

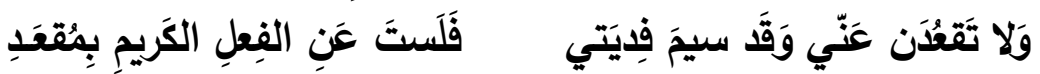

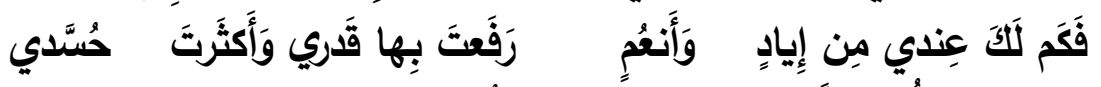

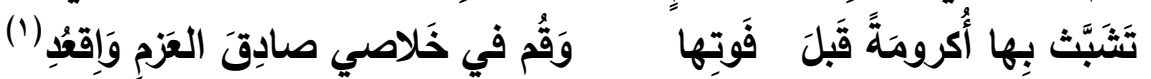

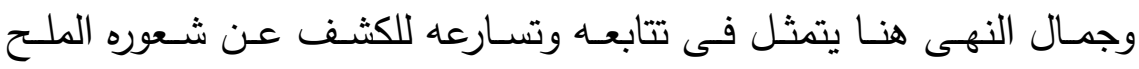
لنجدته، ويتأكد هذا المعنى حين يقدم أسلوب النهى على أسلوب الأمر، وهذا يؤكد خشية أبى فراس من أن يستمع الملك للوشاة والحاقدين فيتقاعس عن فن نجدته فئه يؤكد

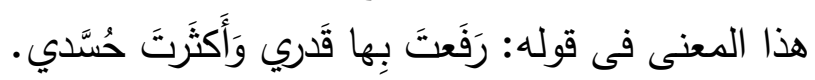

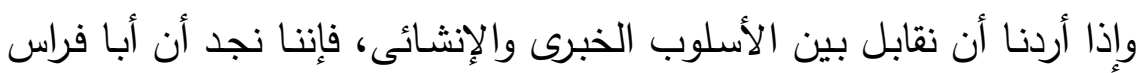

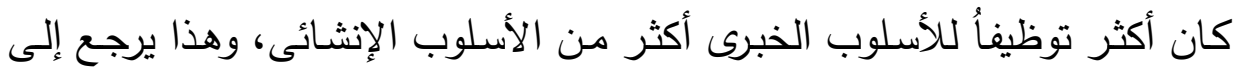
أنه أكثر حاجة لتصوير مشاعره وآلامه فجاء كلامه على سبيل الإخبار، يقول:

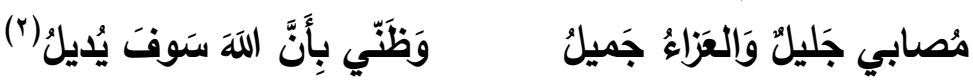
فهو أكثر حاجة لنقل مشاعره وآلامه ليسعى الملك إلى افتدائه.

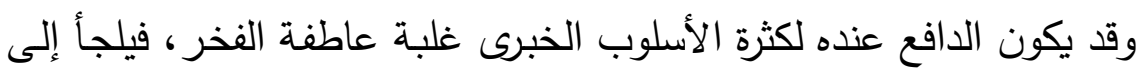

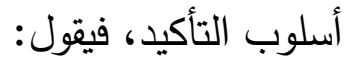

مُعَوَّدَةٍ أَن لائخِلَّ بِها النَصــر

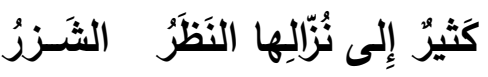

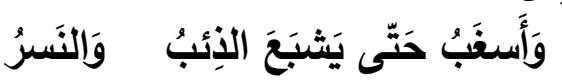

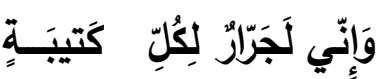

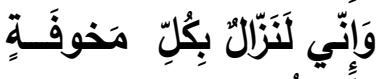

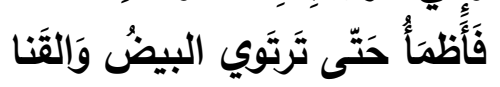

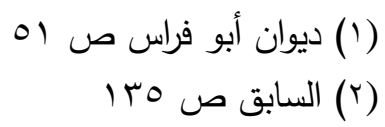


الاغتراب بين أبى فراس والمعتمد بن عباد - دراسة وموازنة

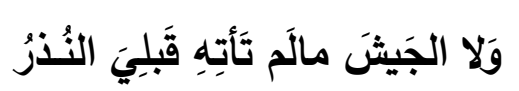

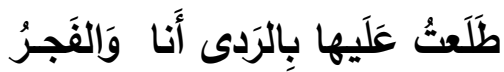

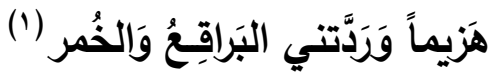

وَلا أُصِبحُ الحَيَّ الخَلوفَ بِغَارَة

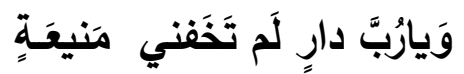

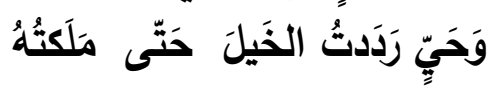

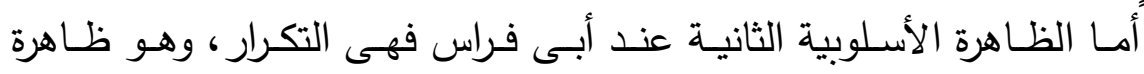

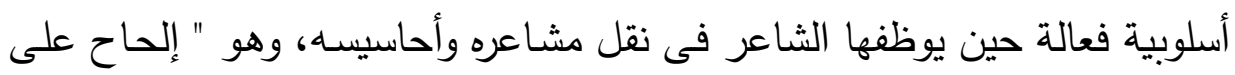

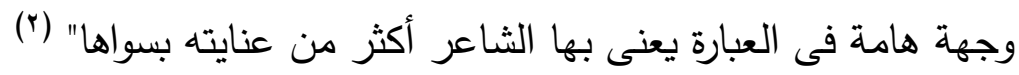

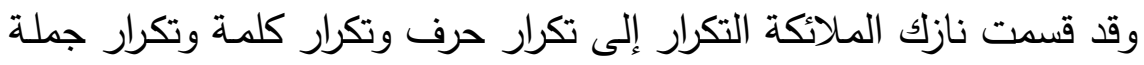
وتكرار مقطع، ومن الضرورى أن تكون الدوافع النفسية لاختيار الأسلوب وطيدة

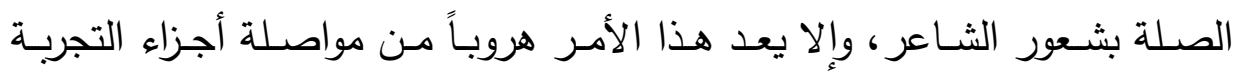
الشعرية، مما يكثف عن نضوب العاطفة. وقد استخدم أبو فراس تكرار الجملة بصورة واضحة تلفت الانتباه فنراه وقد بلغه خبر وفاة أمه مما زاد عليه الأسر قسوة، فيقول:

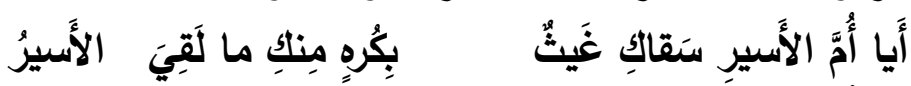

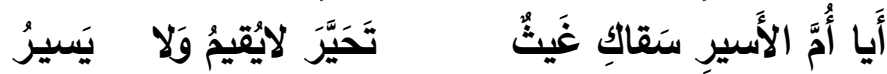

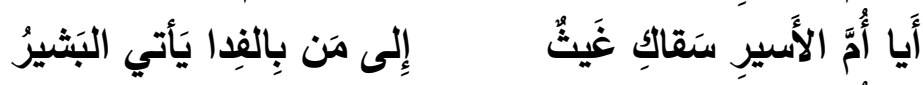

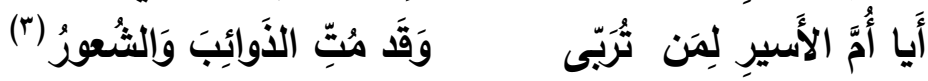

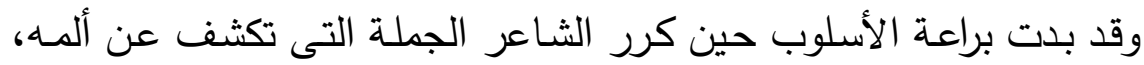

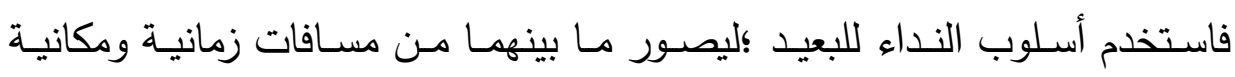

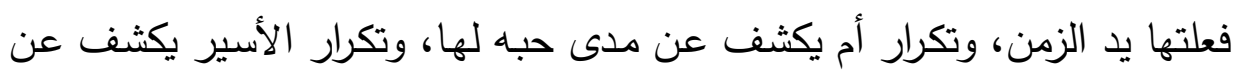

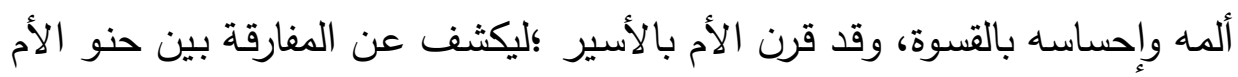

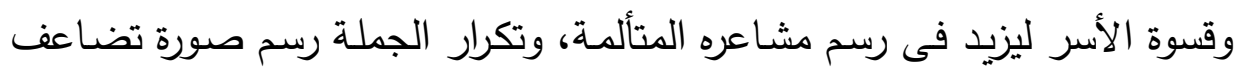
هذا الألم فى نفسـه، وقد كثر أسلوب التكرار فى هذه القصيدة، فقد كرر أيضـا

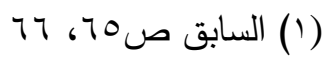

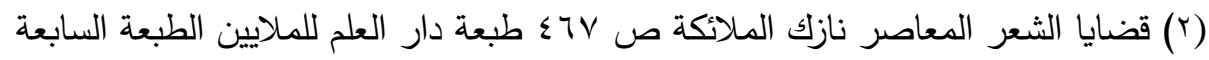

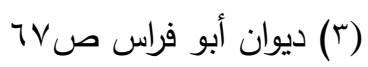


الاغتراب بين أبى فراس والمعتمد بن عباد - دراسة وموازنة

جملة (ليبكيك) فى مطلع أربعة أبيات متتالية، وهذا يكشف عن نفسه الذبيحة، وقد

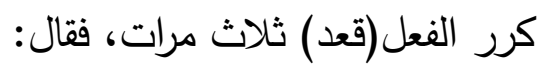

وَلا تَقَطَعِع التَسَآلَ عَنِّي وَتَقْعُدِ

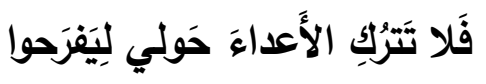

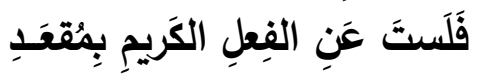

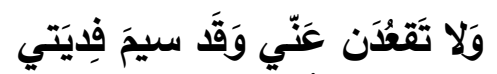

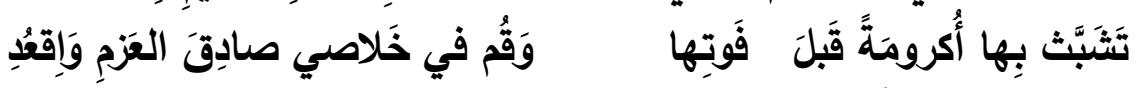

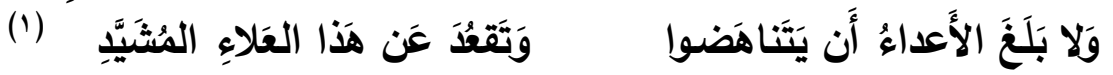

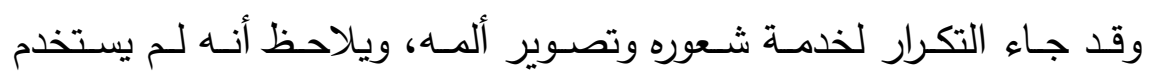

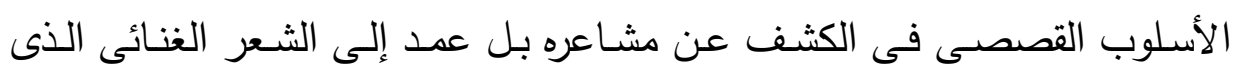
يصور الأوجاع والانفعالات التى تراود نفسه بين الحين والآخر .

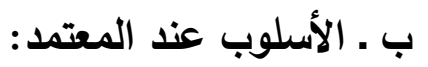
خص المعتمد أسلوب الاستفهام مـن بين الأسـاليب الإنشـائية للتعبير عن الأن

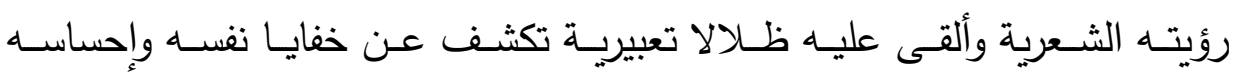

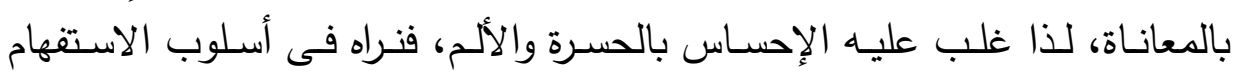
يكشف عن إحساسه بقسوة الحياة، فيقول: دعا لى بالبقاء وكيف يهوى أسير أن يطول به البهاء البهاء

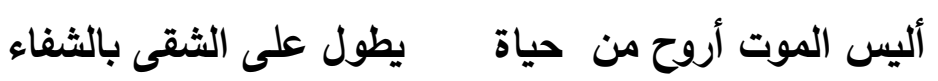

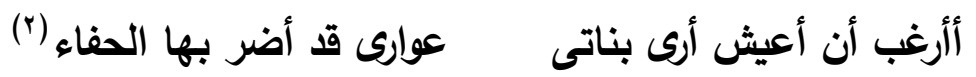

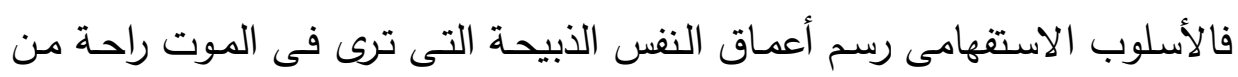

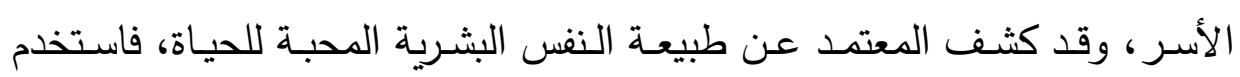

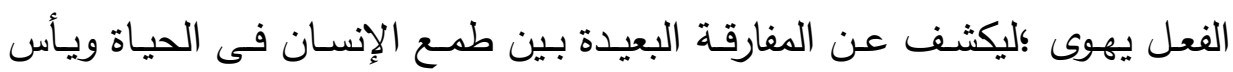
المعتمد منها، ولا ينسى أن يعطينا بعض المبررات لهذا اليأس، فيقول: الحفاء.... أضر ... الثقى....عوارى.

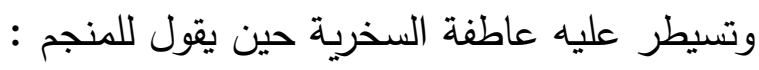

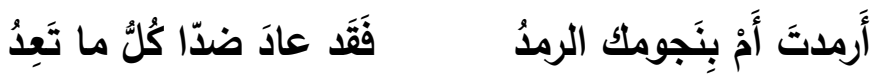

$$
\begin{aligned}
& \text { (1) ديوان أبو فراس ص ال } 0
\end{aligned}
$$

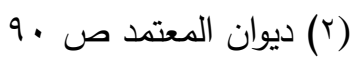


الاغتراب بين أبى فراس والمعتمد بن عباد - دراسة وموازنة

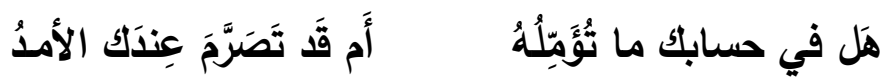

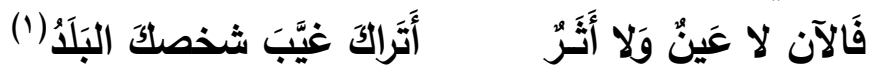

أمسا عن الأسلوب الخبرى فقد بدا بصورة غاية فة فى الروعة والجمال عند

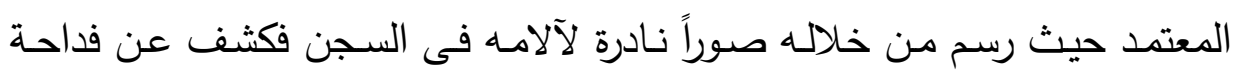
المأساة، يقول:

فَسَاءَلَكَ العيدُ في أَغْاتَ مَأسورا

يَغزلِنَ لِلناسِ ما يَملِكنَ قَطميراً

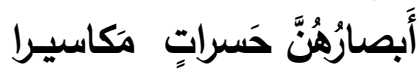

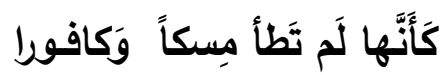

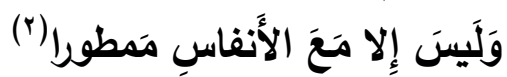

فيما مَضى كُنتَ بِالأَعيادِ مَسرورا

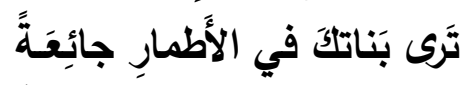

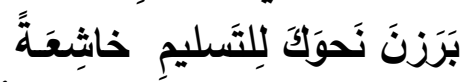

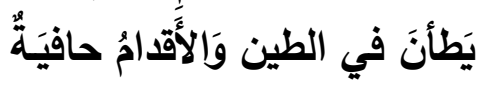

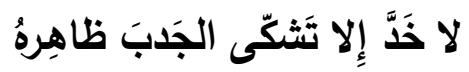

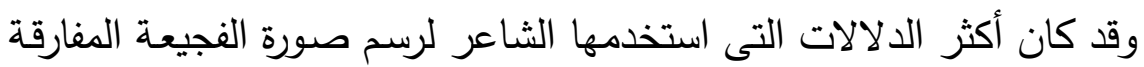
بين الماضى والحاضر وقد ساعده فى ذلك الأسلوب الخبرى. أما أسلوب التكرار فقد استخدم تكرار اللفظ فى موضعين فقال:

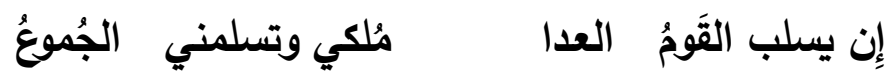

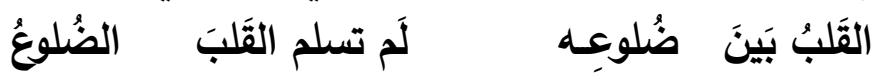

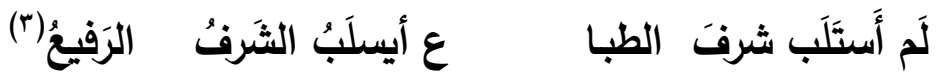
فاللفظ المكرر كشف عن نفسه التى سلبت، ولا تخفى دلالة الفعل سلب في التى الكشف عن رأيه فيمن استولوا على ملكه، واقتران الاستفهام بالفعل فى قوله أيسلب

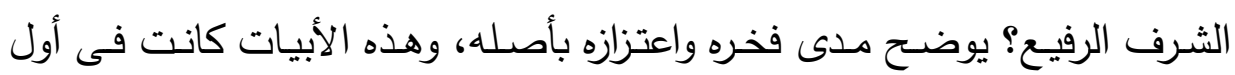
الكارثة، أما وقد أسر فقد بدت مشاعر الألم تسيطر عليه فيوظف التكرار فى رسم

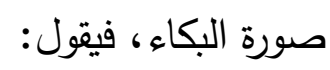

بكَى عَلى أَثْ غِزلانٍ وَآسـادِ

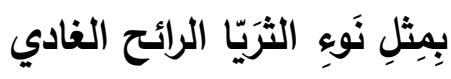

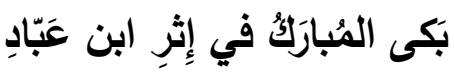
بَكت ثُرَيّاهُ لا غُمَّتَ كَواكِيُهـا

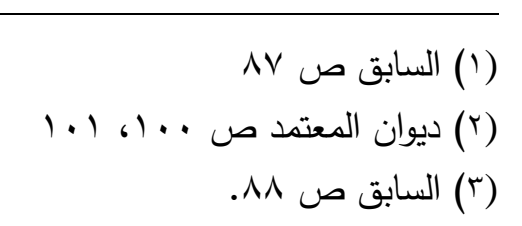

(1) السابق ص (Y)

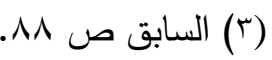

$\Lambda \cdot r$ 
الاغتراب بين أبى فراس والمعتمد بن عباد - دراسة وموازنة

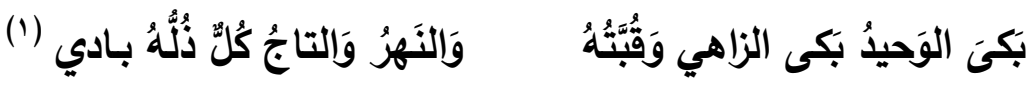
وتكرار الفعل بكى رغم أنها يعبر عن بكاء عناصر الطبيعة من حوله والتى لوهى كانت تشاركه حياة الملك والدعة، إلا أنه يصور بكاءه هو هو ، وهذا التعبير رسم بقوة بكاء

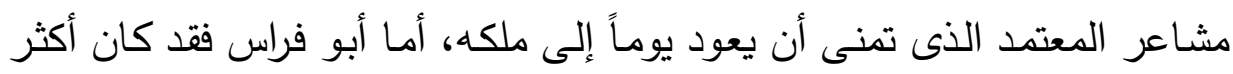
تجلداً وصبراً، ولم ينسب البكاء لنفسه، بل جعل أمه هيى التى تبكى عليه. وبعد فليس معنى هذا تفوق أحدهما عن الآخر وإنما أجاد كل واحد منهما لتهاء

\section{ثانياً: الصورة الثعرية} فى التعبير عن مشاعره.

غلب على صور القدماء أن تكون بيانية بما تتقسم إليهه من تشبيه استعارة

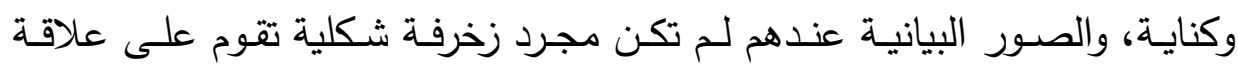

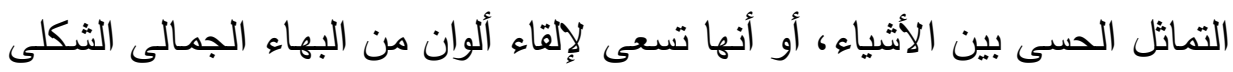

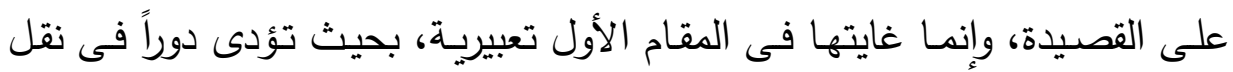

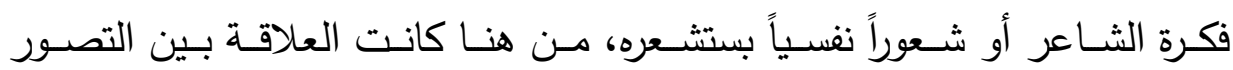

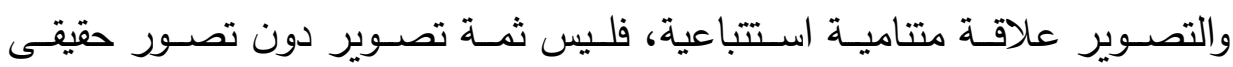
يستشعر الثاعر أبعادهوزوراياه النفسية.

وعلى هذا فليس وظيفة الصورة إبراز التشابه بين العناصر ، وإنما غايتها " التقريب بين حقيقتين متباعدتين كثيراً أو قليلاً، وكلما كانت العلاقات بين بين الحقيقتين اللتين يقرب بينهما الشعر بعيدة ودقيقة، كانت الصورة أقوى وأقدر على لقئين التأثير وأغنى بالحقيقة الشعرية " (؟).

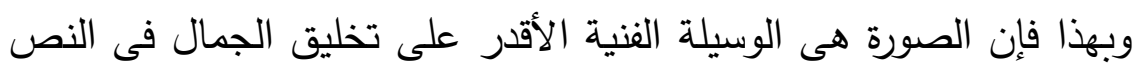
الشعرى " فهى تبعث الحياة فى الجمادات، وتبث الروح فى كل ما يتتاوله الشاعر لوريل فيها، من مظاهر الحياة والواقع وجوامد ما يقع تحت الحس فى الطبيعة، فتتعانق (Y) عن بناء القصيدة العربيـة الحديثة د/ على عشىى زايـد: ص • V. دار مرجان للطباعـة.

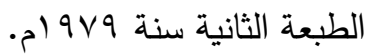


الاغتراب بين أبى فراس والمعتمد بن عباد - دراسة وموازنة

هذه الظواهر كلها بعضها مع بعض، وتتآلف فى تعاطف وتجاوب، فهى وسيلة

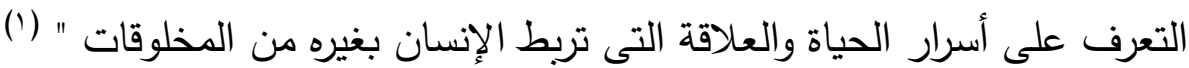
أ. الصورة الشعرية عند أبى فراس: اعتمـد أبو فراس على التشبيه في شعره باعتباره وسيلة تصـويرية، وكـان

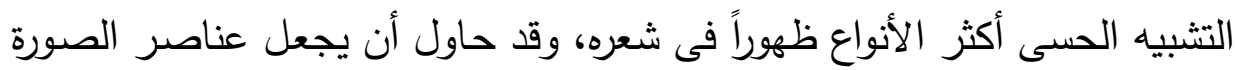
الشعرية أكثر التصاقا بشعوره، فنراه يقول فى وصف التفر محبوبته:

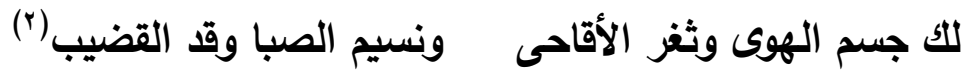

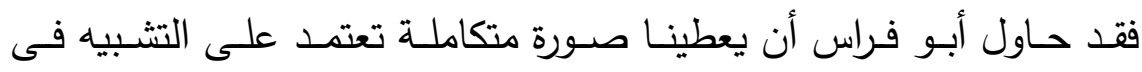

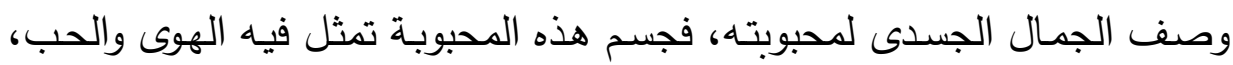
وهذا وصف عام لجسدها أراد الشـاعر أن يلقى عليه نوعاً من التقصيل الذى لا لانهان يخلو من التقليد لمعانى وصور السابقين، فثغر محبوبته ثغر الأقاحى، معتمداً فى لهى

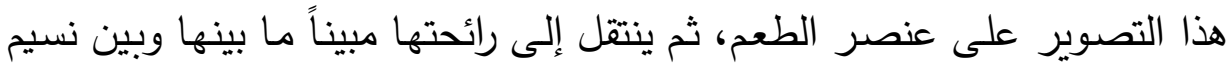
الصبا من تشابه شديد، ثم ينتقل إلى عنصر آخر وهو الشكل العام وهو أن قدها كقد القضيب، وصسور (جسم الهوى) فيها بعض الغدوض لأنسه جمع بين أمرين أحدهما حسى (الجسم) والآخر معنوى (الهوى)فما هذا الذى يدعوه جسم الهوى ؟

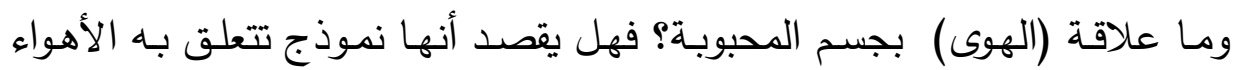

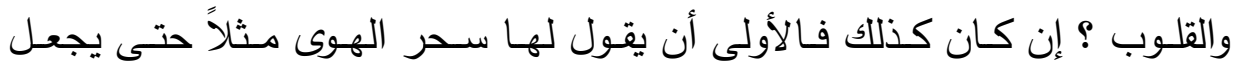

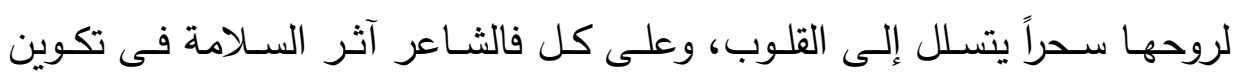

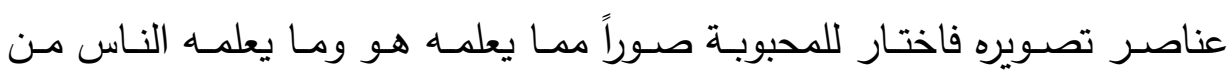

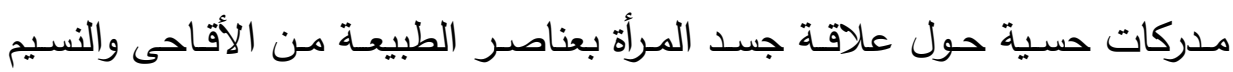

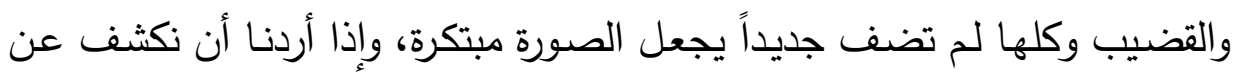

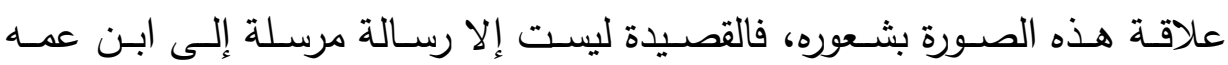
يستجده لذا جاءت القصيدة تقليديـة البناء تحذو حذو السـابقين فجاءت صـورها

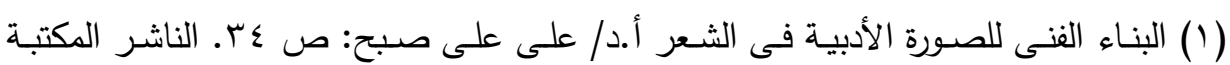

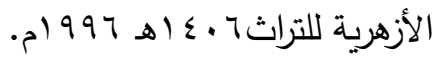

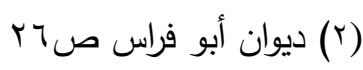


الاغتراب بين أبى فراس والمعتمد بن عباد - دراسة وموازنة

أيضا تقليدية خاصة وأن الغزل فى مطلعها لمجرد التقليد فهى أشبه بقصائد المدح

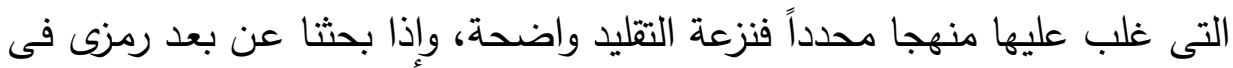

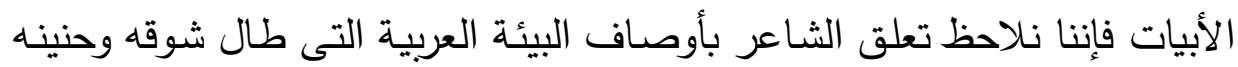
إليها فهو يتشوق إلى دياره وإن بدا الكلام عن محبوبته.

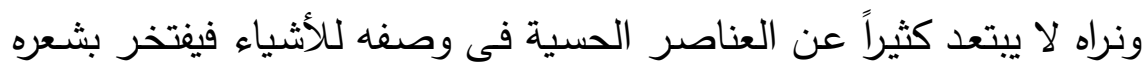
الذى هو ألذ من الماء البارد وأكثر جمالاً من اللؤلؤ المنثور ، فيقول

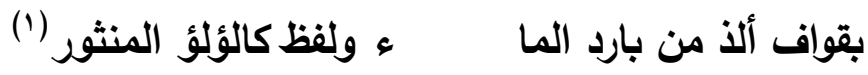

والصورة تكثف عن خيلاء وغرور دأبت نفس أبى فراس على ترديده، وقد

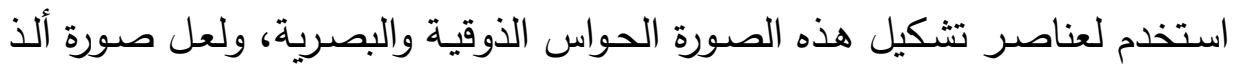

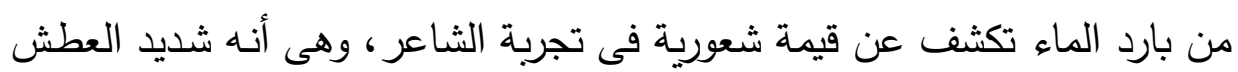

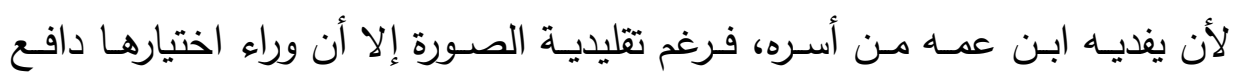
شعورى يؤكد صدق التجربة عنده.

ومثل هذا الضرب من التصوير الذى يعتمد على التشبيه نراه فى قوله:

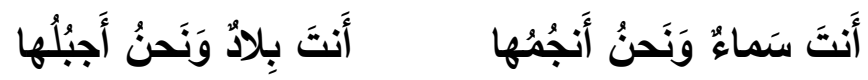

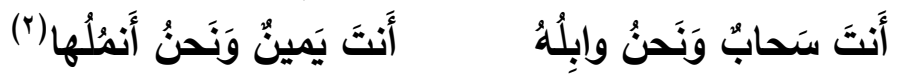

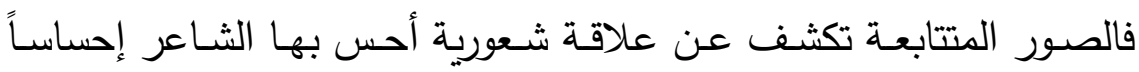

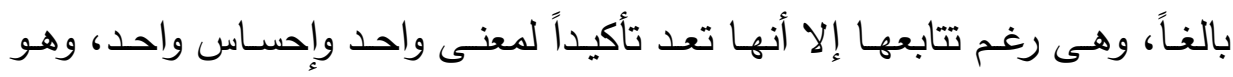

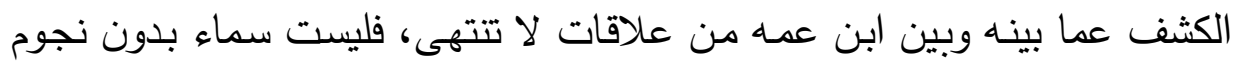
(تتيرها)ولا بلاد بلا جبال (تحميها) ولا سحاب إلا وينزل غيثاً (حتى يتحقق معنى

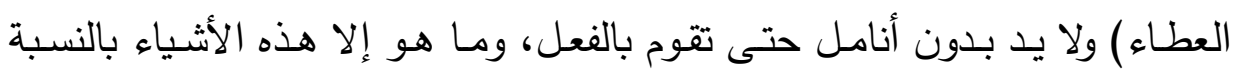

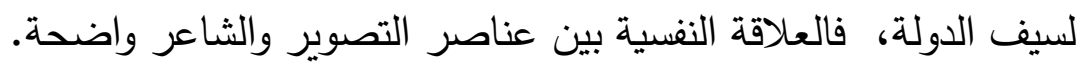
ونراه يعطينا صورة تشبيهية للزهو الذى عرف به وهى سمة ليست لله وحده بل لحصانه، فيقول:

كَأَنَّ تُرابَها قُطبُ النِبالِ (1) وَمَهري لايَمَسُّ الأَرَّنَ زَهواً

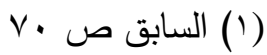

$$
\begin{aligned}
& \text { (r) ديوان أبو فراس ص سب صا •V (1) }
\end{aligned}
$$


الاغتراب بين أبى فراس والمعتمد بن عباد - دراسة وموازنة

فيعتمــ فى هـذه الصـورة على العناصـر الحركيـة والأداة كـأن ذات ظـلال

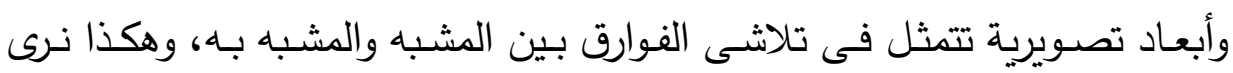

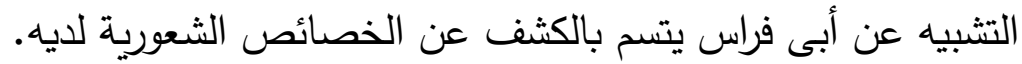
وقد استخدم الاستعارة فى قوله:

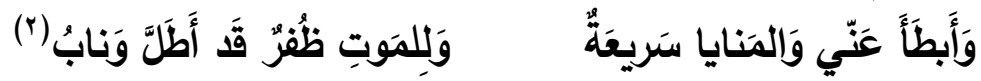

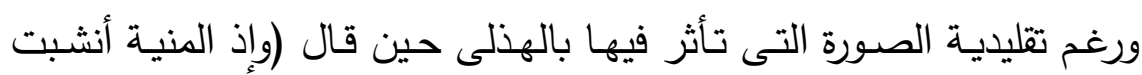
أظفارها) إلا أنها كشفت بوضوح عن إحساس الثاعر ، فنرى صورة تقاعس سيف

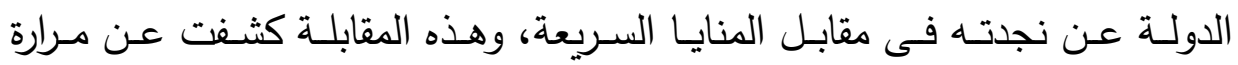

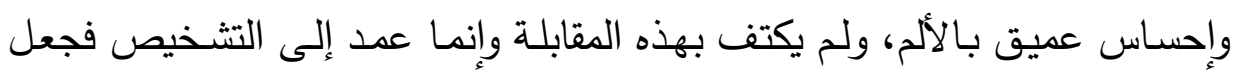
المنية وحشاً فاتكاً، وقد أضاف إلى صورة الوحش صورة أطل ليجعل الأمر قريباً منه، وليوضح مدى الأزمة التى يعانيها.

وقد استخدم أسلوب الكناية والرمز ، من ذلك قوله مصانه مصوراً ملازمته للحرب:

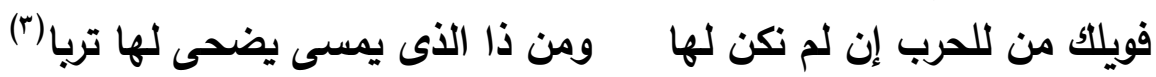
وهى كناية عن ممارسة قومه لأعمال الحرب حتى صاروا لها رفقاء.

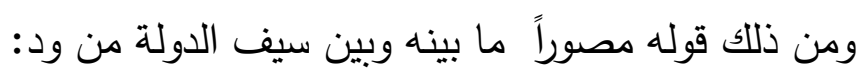
في حُضوري مُحافِظٌ في غِيابي

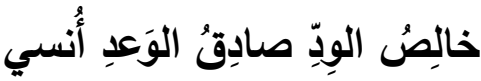

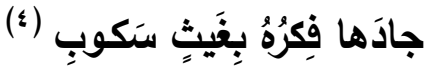

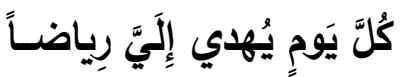
وهى صورة رائعة الجمال اعتمد فيها الشـاعر على تصوير عقله بالروضـة

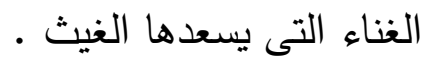
ومن الصور الكنائية أيضا قوله:

متى تخلف الأيام مثلى لكم قتى طويل نجاد السيف رحب المقلد(•) (1) السابق ص و ب اوقطب النبال هى نصل السهام وهى حديدة فى مقدمة السهام. (r) السابق ص الابق صل 10.

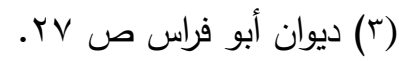

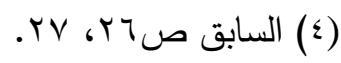

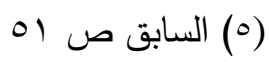




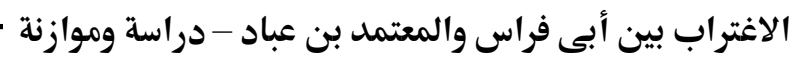

وهى كناية عن طوله وضخامته التى تلقى عليه وقاراً وهيبة. ومن ذلك أيضاً.

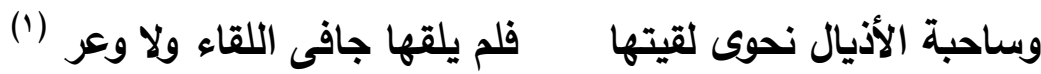

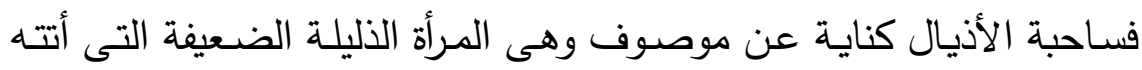
تطلب العفو، ومن الصور الرامزة البديعة قوله:

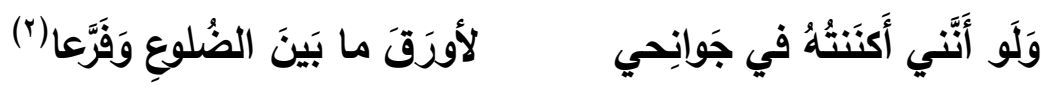
والهى كناية عن عطفه وسعة صدره.

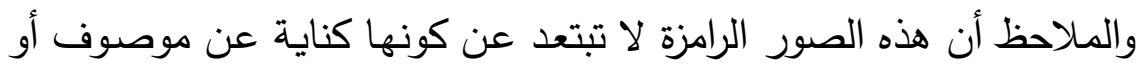
صفة فليس وراءها عمق الرمز الذى نراه فى الثعر الحديث ورغم هذا فهى معبرة

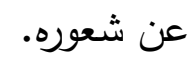

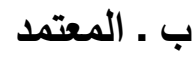

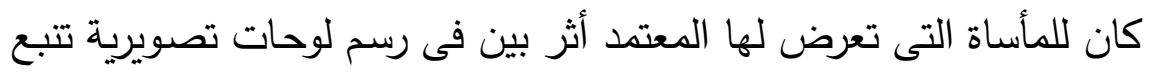

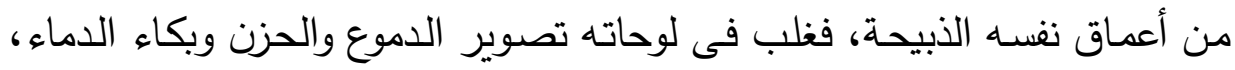

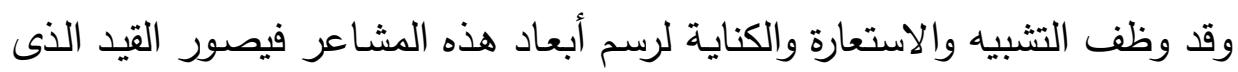
يرى فيه ذلاً لايعدله ذل فيقول:

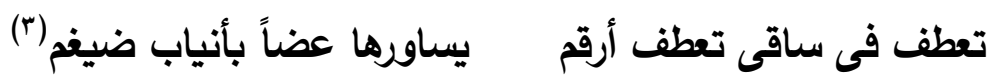

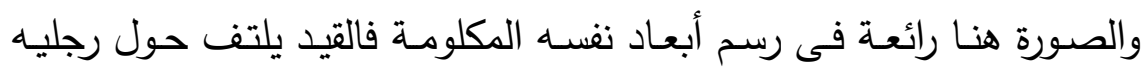

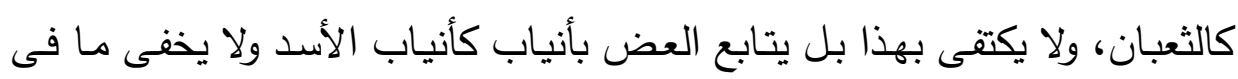

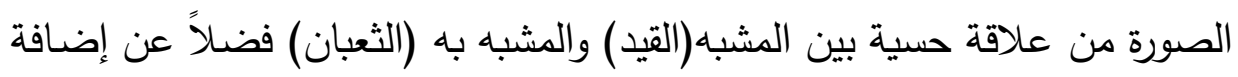

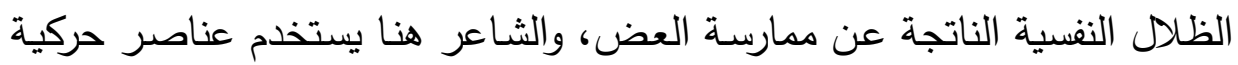

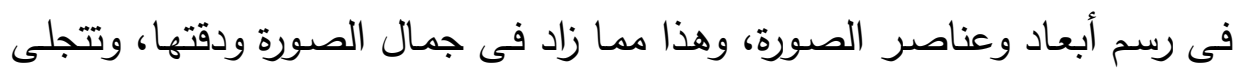

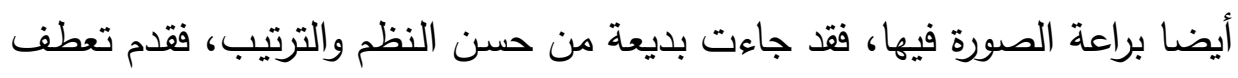

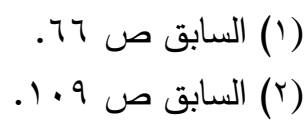

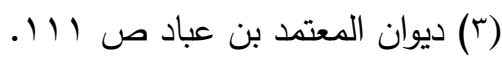




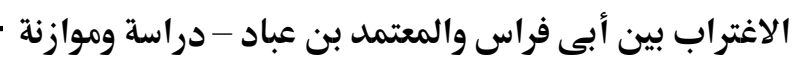

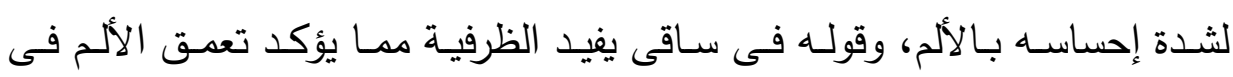

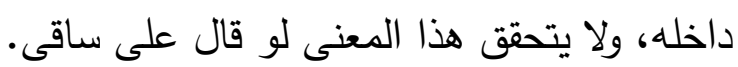

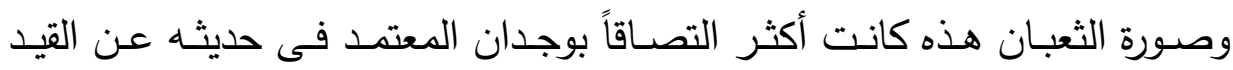
فيقول:

وقد كان كالثعبان رمحك فى الوغى فغذا عليك القيد كالثعبان (1) وقد جمع بين صورة القيد والرمح وتشبيهما بالثعبان لإضافة بعض المالامح

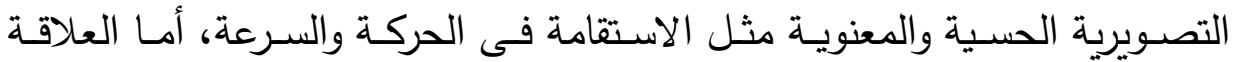

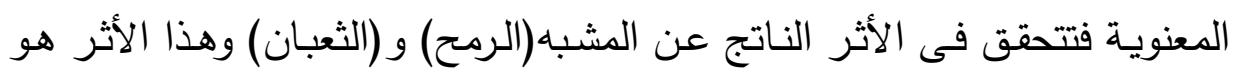

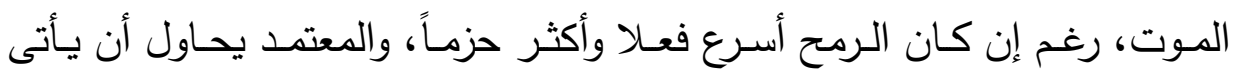
بصورة مقابلة تبين ما كان له فى الماضى من قوة (فرمحه كالثعبان) وما هو عليه اليوم من ذل (فقيده كالثعبان) فكأن كل ما فى الحياة تكاتف ليكون لهون عوناً عليه. ونراه يصور بطولته وشجاعته إثر ثورة ابنه عبد الجبار ، فيقول:

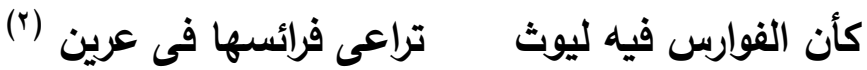

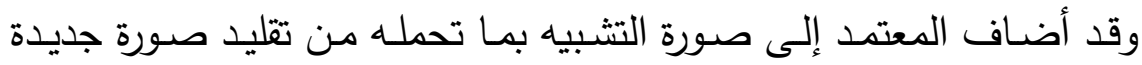

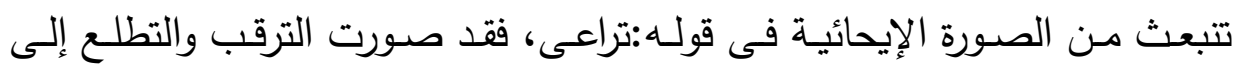
الفريسة وهذا ما يفعله الفرسان.

ويأتى أيضا بصورة تقليدية أيضاً يصف من خلانها مانها قوة يوسف بن تاشفين فيقول:

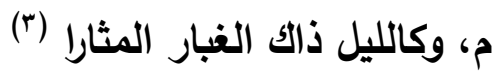
رأينا السيوف ضحى كالنجو والصورة واضحة التأثر بصورة بشار كأن مثار النقع فوق رؤسنا...... ورغم

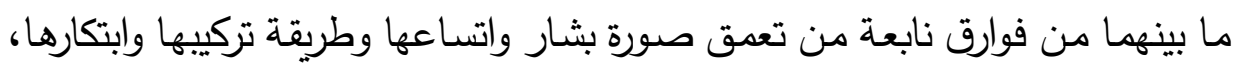

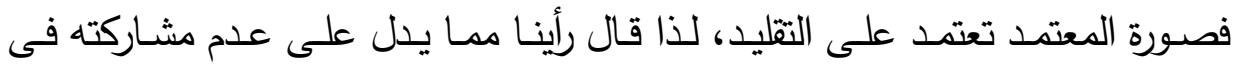

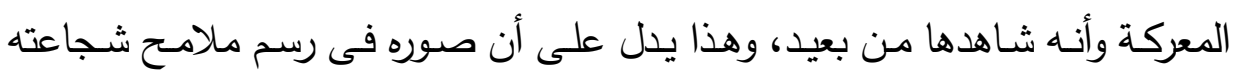

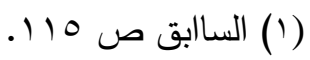

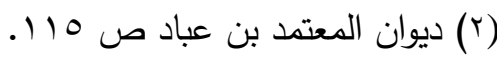

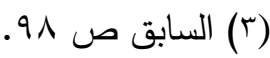


الاغتراب بين أبى فراس والمعتمد بن عباد - دراسة وموازنة

أضسف من صوره فى رسم آلام السجن، فقد أحسن فى تصوير النكبة وأثرها على عناصر الطبيعة فنرى القصور تبكى، يقول:

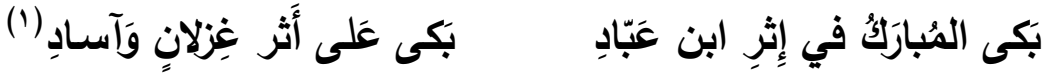
فقد شبه القصـر بالإنسـان ثم حذف المشبه ورمـز إليهه بشـئ من لوازمـهـ(البكاء)

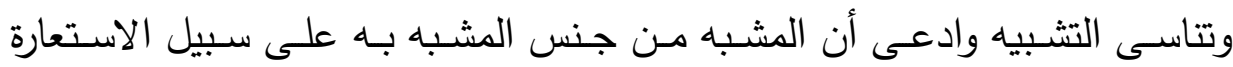
المكنية، وأروع من هذا وأجمل قوله مخاطباً قبره:

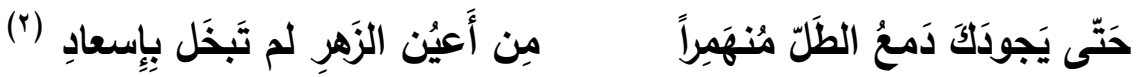
ويعدد إلى الاستعارة التصريحية فى تصوير هذه الآلام فيقول:

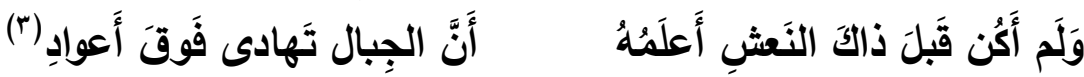
وجمال هذا اللون التصويرى يتمثل فى مقدرة الثاعر على خلق حالة من المشاركة بينه وبين عناصر الكون وهذا مما أضفى على شعره بعض العمق، فنراه يقول: وَكَم مِن مِنبَرِ حَنّت إِلَيسهِ وقد استخدم بعص الصور الموحية التى تفيض بالإيحاء والإشعاع والظلال مرلمديل من ذللك قوله:

قضى وطراً من أهله كل نازح وكر يدوى علة فى الجوارح وب(•)

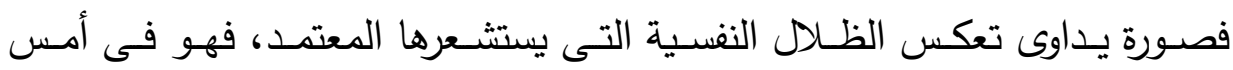
الحاجة إلى الدواء، ورغم هذا فقد أخطأ فى صياغة الصورة فى قوله:

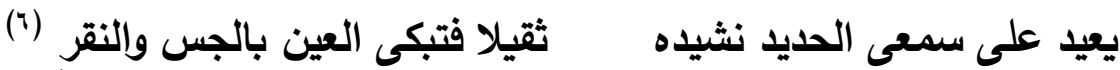

فليس من المقبول أن يكون صوت الحديد والقيود نشيداً .

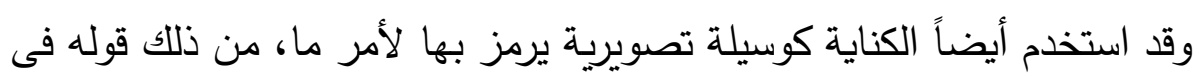
تصوير الألم الذى أبكاه دمعاً ممتزجاً بدم، فقال:

$$
\begin{aligned}
& \text { (1) السابق ص } 90 \\
& \text { (r) السابق ص (r) } 97 \\
& \text { (r) السابق ص (r) } 97
\end{aligned}
$$

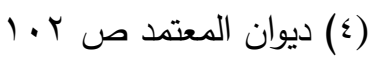

$$
\begin{aligned}
& \text { (0) السابق ص به }
\end{aligned}
$$

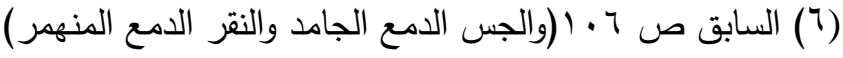


الاغتراب بين أبى فراس والمعتمد بن عباد - دراسة وموازنة -

دَمعي يَنوبُ لَكُمُ عَن الأَنَوايَ

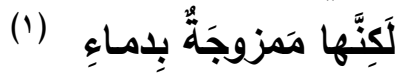

خَرَجوا لِيَستَسقوا فَقُلتُ لَهُم

قالوا حقيق في دَمعِكَ مُقِنُِّ

وهى كناية عن الحزن ومن ذللك قوله فى تصوير غدئ غدر الحياة:

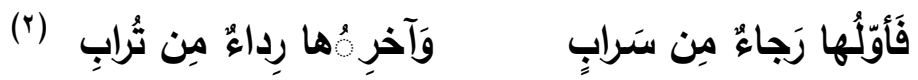

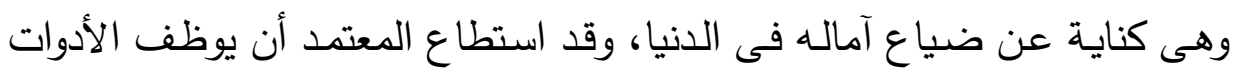
التى تثير الوجدان، فأجاد حين جعل تراب القبر رداءً حين يقابل بين آمال الحياة

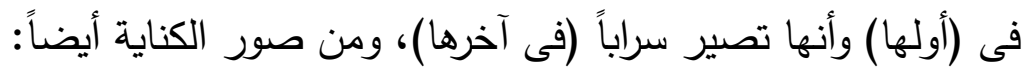

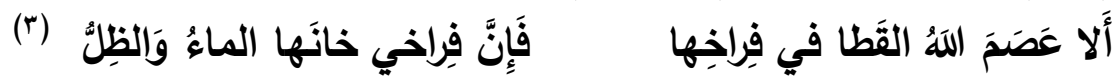

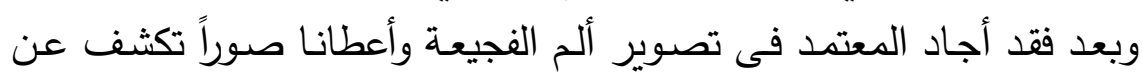
مكنونه وشعوره الدفين.

وقد رسم شـاعرينا لوحات تصويرية غاية فى الروعة والجمال وتحمل كثيراً

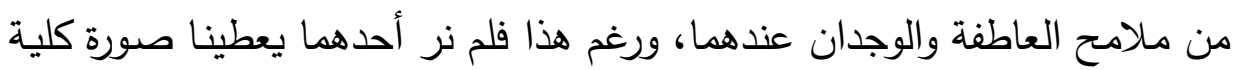

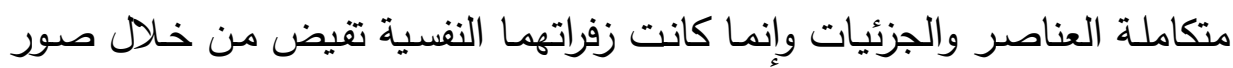

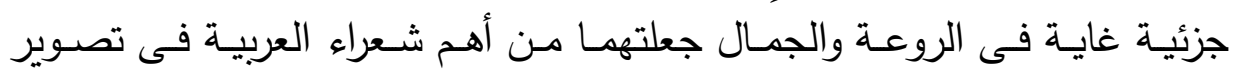

\section{ثالثاً: الموسيقى الثعرية}

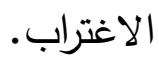

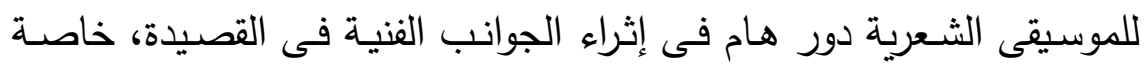

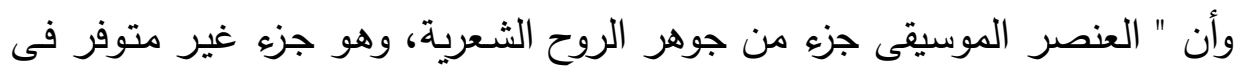
النثر وإذا توفر فيه أصبح شعراً، وهناك حد أدنى لهذا التوفر إذ لابد من التهـ التزام

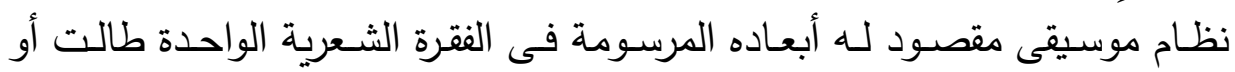

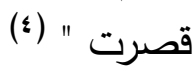

$$
\begin{aligned}
& \text { (1) السابق ص } 19 \\
& \text { (r) السابق ص r (r) } \\
& \text { (r) السابق ص السابق صل } 1111
\end{aligned}
$$

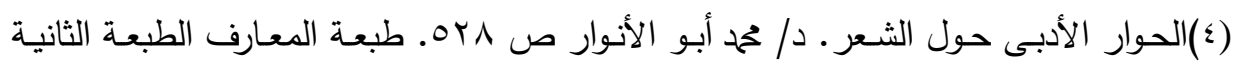

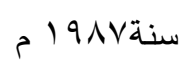


الاغتراب بين أبى فراس والمعتمد بن عباد - دراسة وموازنة

ويجب التنبيه فى قول الدكتور محم أبو الأنوار إلى أنـه لا ترقى الموسيقى

وحدها لتنقل النثر إلى الشعر اللهم إلا إذا كان النثر وجدانياً.

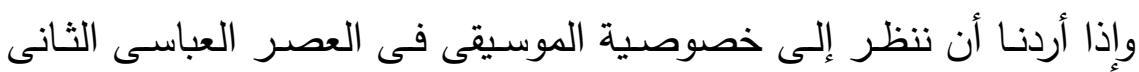

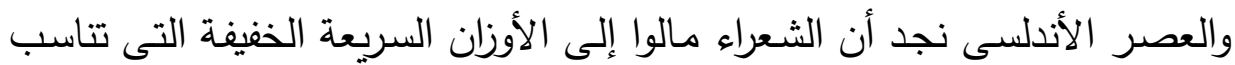

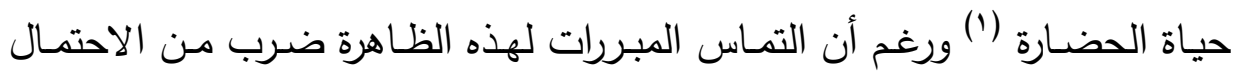

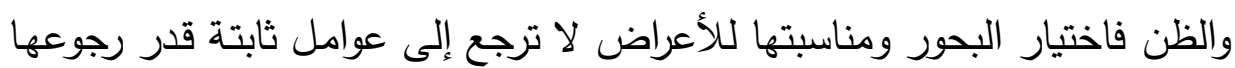

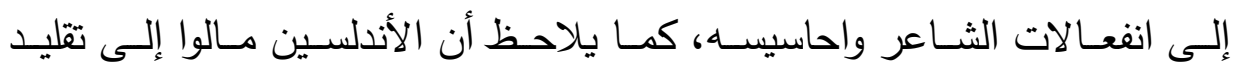

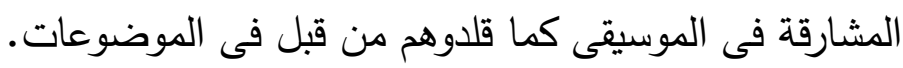
وسوف نطالع نوعية التشكيل الموسيقى عند شاعرينا:

أ. أبو فراس

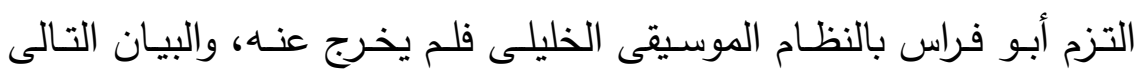

\begin{tabular}{|c|c|c|}
\hline النسبة المئوية & عدد القصائد & البحر \\
\hline$\%$ \%, А & $1 \leq$ & الطويل \\
\hline$\% \backslash 7,7$ & 7 & الوافر \\
\hline$\% \wedge, \Gamma$ & r & الكامل \\
\hline$\% \wedge, \Gamma$ & r & مجزوء الكامل \\
\hline$\% \wedge, \Gamma$ & r & البسيط \\
\hline$\% 0,0$ & r & الخفيف \\
\hline$\% r, v$ & 1 & المتقارب \\
\hline$\% r, v$ & 1 & السريع \\
\hline$\% r, v$ & 1 & المنسرح \\
\hline$\% r, v$ & 1 & المقتضب \\
\hline$\% r, v$ & 1 & مجزوء الرمل \\
\hline
\end{tabular}

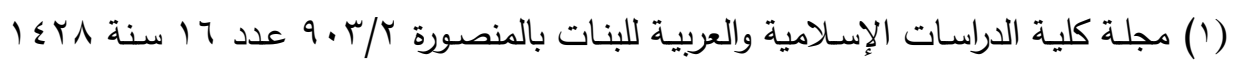
r... $r$ 
الاغتراب بين أبى فراس والمعتمد بن عباد - دراسة وموازنة

\section{مجموع القصائد بr قصيدة}

والملاحظ أنه استخدم البحور التامة أكثر من البحور المجزوءة.

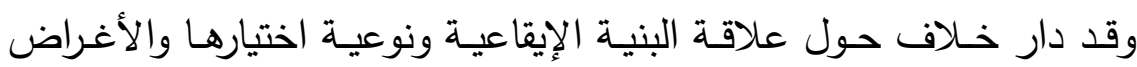

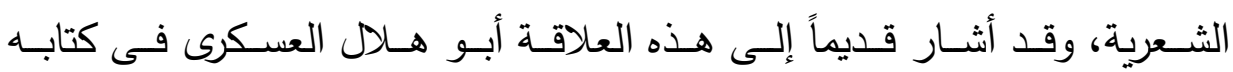

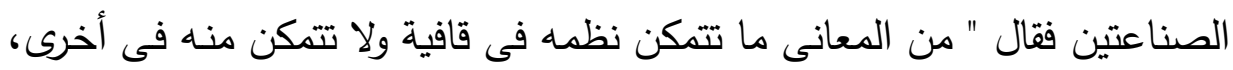

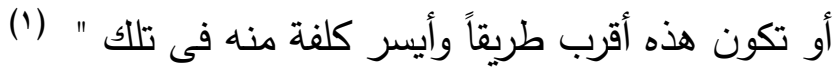

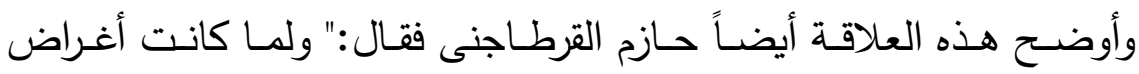
الشعر شتى وكان منها ما يقصد به الجد والرصانة وما يقصد به الهزل والرشاقة،

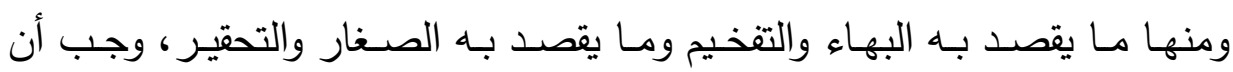

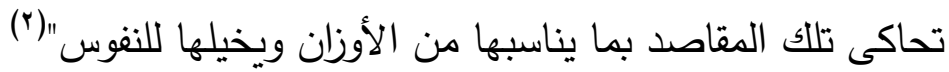
وقد رفض عدد من النقاد وجود هذه العلاقة بين الأوزان والأغراض الثعرية الأنية

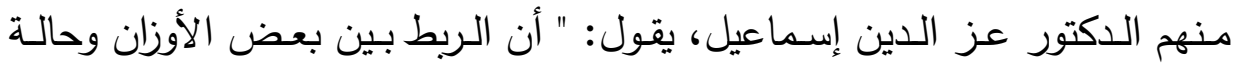

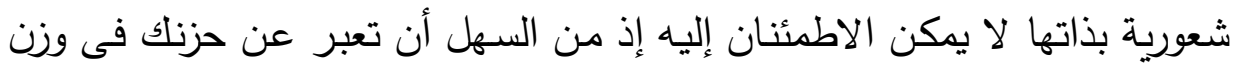

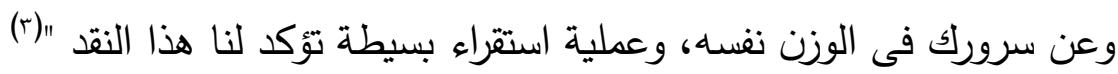

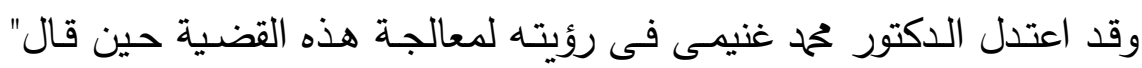
والحق أن القدماء من العرب لن يتخذوا لكل موضوع من هذه الموضوعات وزنـا

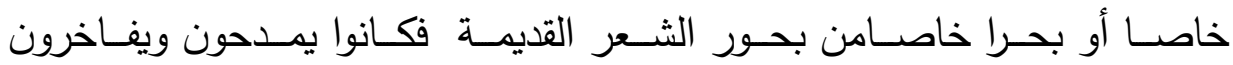
ويتغازلون فى كل بحور الشعر ، وتكاد تتفق المعلقات فى موضوعها وقد نظمت

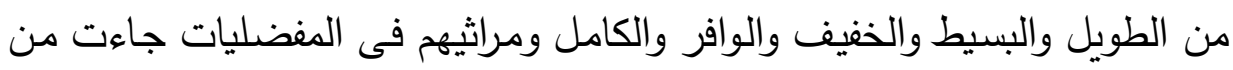

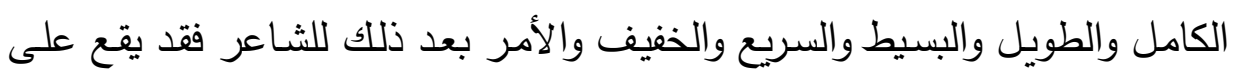

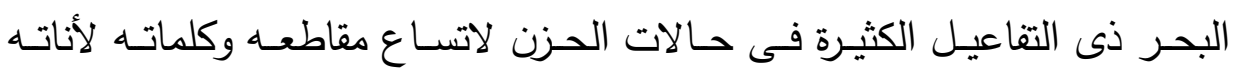

(1) الصناعتين أبو هلال العسكرى ص الأباء

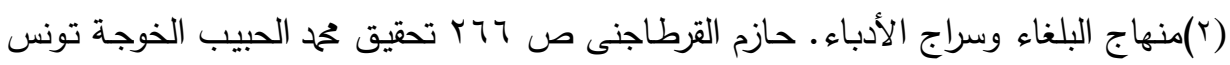
م) 974

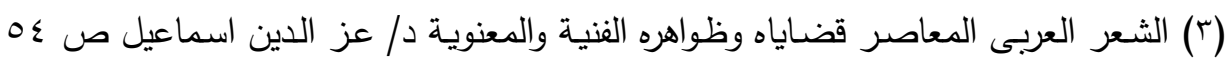
دار الفكر العربى. 
الاغتراب بين أبى فراس والمعتمد بن عباد - دراسة وموازنة

وشكواه محبا كان أو راثيا، أو لملاعمة موسيقاه لأغراضـه الجدية الرزينـة من فخر

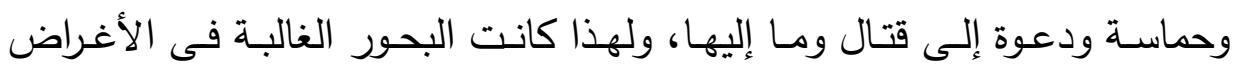

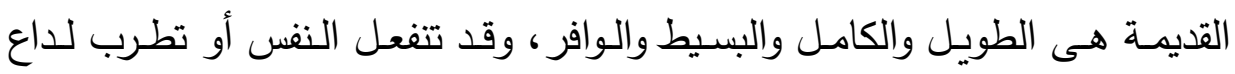

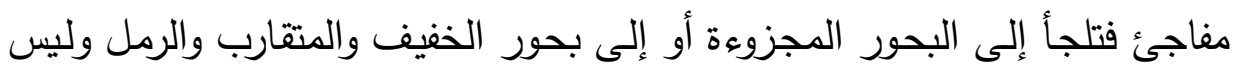
هذا سوى تقرير مجمللا يقوم مقامـه قاعدة وكل بحر بعد ذللك قالب عام يستطيع

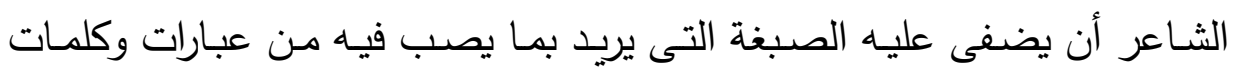

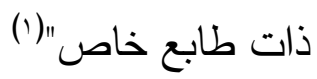
وقد لاحظنا أن أبى فراس يميل إلى ختيـار البحور التامـة والسبب فى ذل

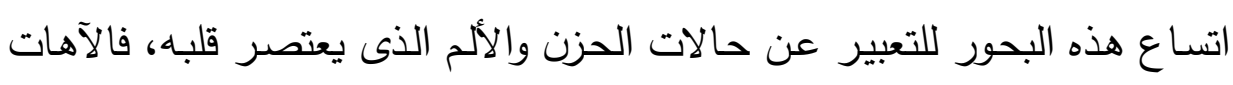

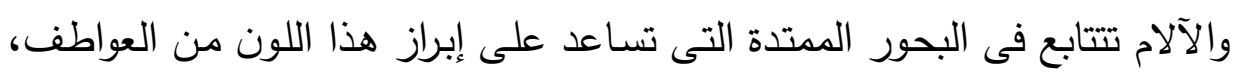
وقد كثر عنده توظيف بحر الطويل وقد ذكر الدكتور إبراهيم أنيس أن بحر الطويل أكثر البحور وروداً فى شعر القدماء وهذه الإحصائية تؤكد هذا الرأى. ولنظظر إلى ملامح امتداد النفس الشعرى عند أبى فراس فى في إحدى روه رومياته الرائعة وهى من بحر الطويل يقول:

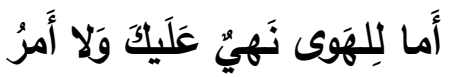

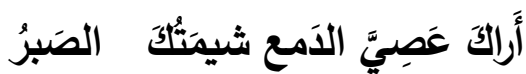

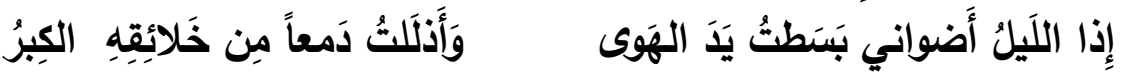

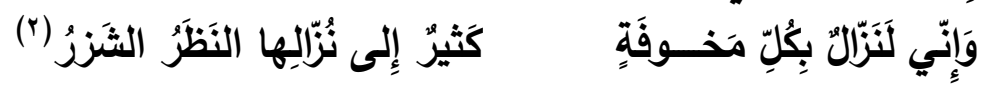
فمشاعر الألم تعتصر قلبه فيى أسره وفراق محبوبته التى هي رمز رئه لبلاده،

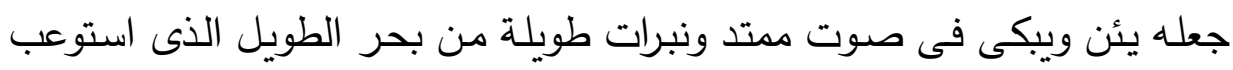
قدراً كبيراً من الانفعالات المتدفقة الممتدة.

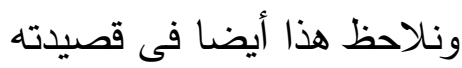

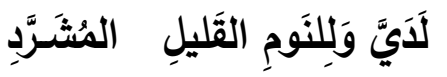

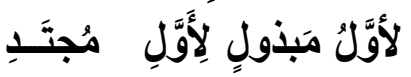

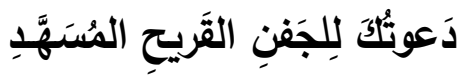

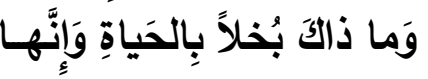

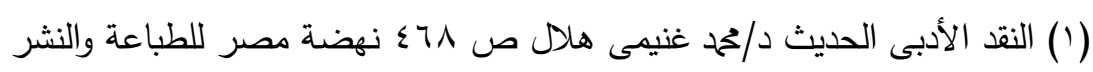

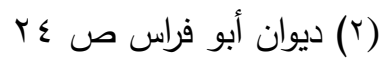


الاغتراب بين أبى فراس والمعتمد بن عباد - دراسة وموازنة

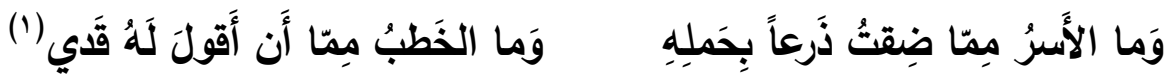

$$
\text { وهى أيضا من بحر الطويل. }
$$

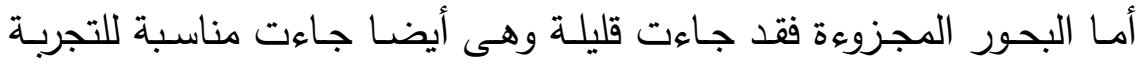

والعاطفة فنراه فى قصيدته التى مطلعها:

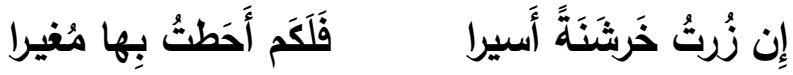

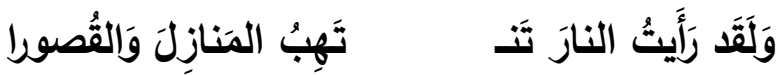

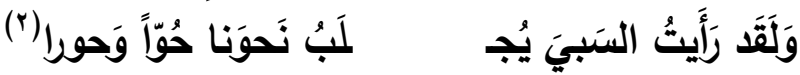

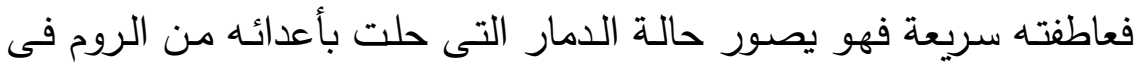

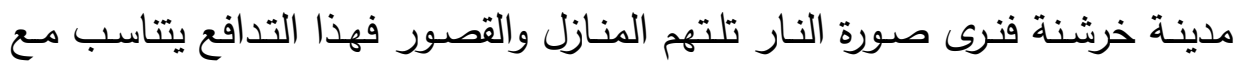
إيقاع بحر الكامل المجزوء. وبهذا نرى أن الموسيقى عنده منسجمة مع الاغتراب ومعانيه.

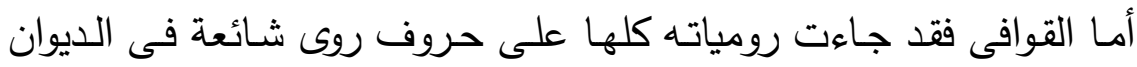
الشعرى العربى، فلم يشأ أن يأتى بالغريب من القوافى من مثل حرف الظاء والخاء

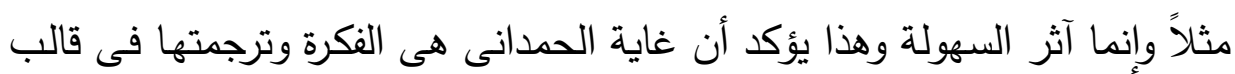
تصويرى تعبيرى.

فقد استخدم حرف الباء فى إحدى عشرة قصيدة، واللام فى سبع قصائد،

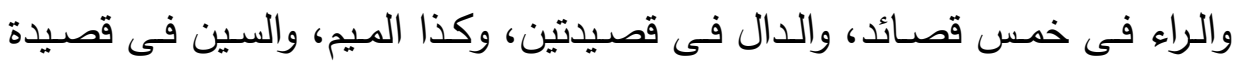
واحدة وكذا العين والياء. وبعـد فملامـح الموسـيقى الخارجيـة عند أبـى فراس لـم تخـرج عـن الإطسار التقليدى، وقد استخدم أبو فراس بعض ملامح الموسيقى الداخلية التى تحمل جانباً

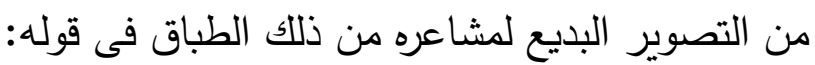

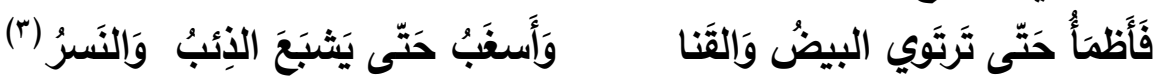

$$
\begin{aligned}
& \text { 0. (1) السابق ص (Y) } \\
& \text { 9V (r) السابق صن (r) }
\end{aligned}
$$

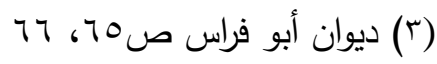


الاغتراب بين أبى فراس والمعتمد بن عباد - دراسة وموازنة - لـ

فهى صسورة رائعـة رامـزة تصسور كريم خصـاله، فأظمأ تقابل ترتوى وأسـب تهب

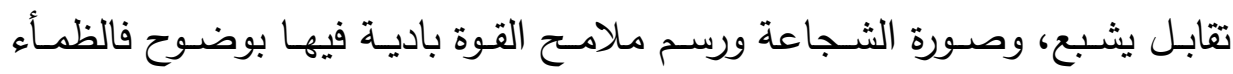
يلازمه حتى ترتوى السيوف من دماء الأعداء، وكذلك صورة أسغب ويشبع، فهو

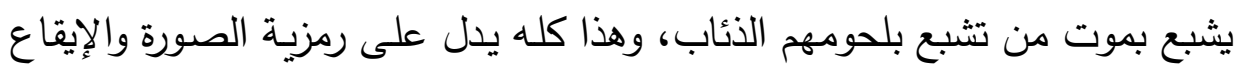

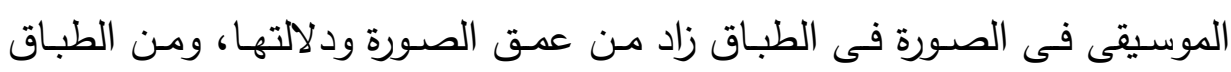
قوله:

وَكَمْ يَنُْصونَ الفَضلَ وَالَهُ واهِبُ (1)

هُهُ يُطِفِؤونَ المَجدَ وَالمَهُ موقُِِّ

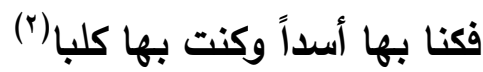

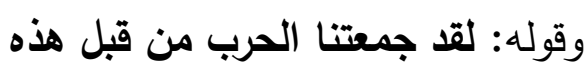

لنا الصدر دون العالمين أو القبر (ז) وقوله: ونحن أناس لا توسط بيننا

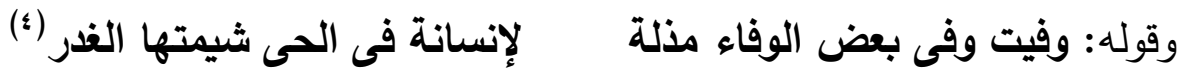

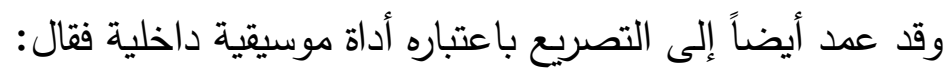

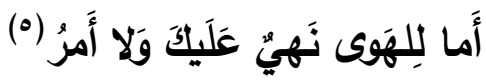

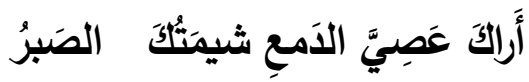

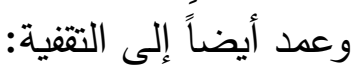

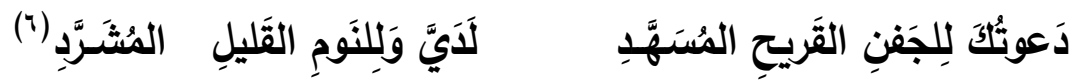
واستخدم أيضاً حسن التقسيم فى قوله:

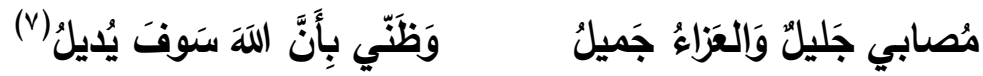

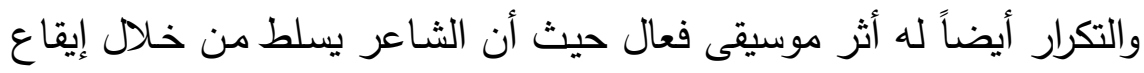

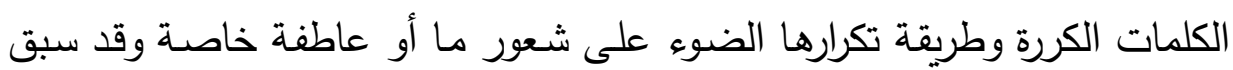
الحديث عنه فى سالف الدراسة.

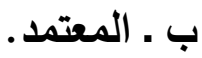

\begin{tabular}{|c|}
\hline (') السابق ص §؟ \\
\hline r r السابق ص rV \\
\hline (r) السابق ص TV \\
\hline (§) السابق ص 107 \\
\hline (0) ديوان أبو فراس ص ع 7 \\
\hline ( آ) السابق ص •0 \\
\hline 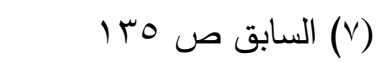 \\
\hline
\end{tabular}


الاغتراب بين أبعى فراس والمعتمد بن عباد - دراسة وموازنة

وقد استخدم المعتمد أيضـاً البحور التامـة أكثر من البحور المجزوءة وهذا

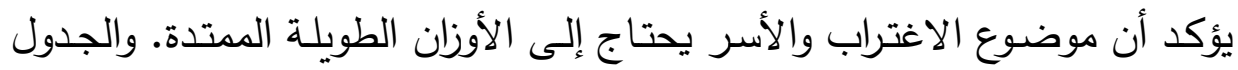
التالى يوضح البحور التى استخدمها المعتمد في أشعاره:

\begin{tabular}{|c|c|c|}
\hline النسبة المئوية & عدد القصائد & البحر \\
\hline$\%$ \%^ & 11 & الطوبل \\
\hline$\%$ r. & $\wedge$ & البسيط \\
\hline$\% \backslash r, \wedge$ & 0 & الكامل \\
\hline$\% r, 0$ & 1 & مجزوء الكامل \\
\hline$\% \vee, 7$ & r & الوافر \\
\hline$\% \vee, 7$ & r & المتقارب \\
\hline$\% 0,1$ & r & 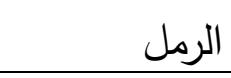 \\
\hline$\% r, 0$ & 1 & مجزوء الرمل \\
\hline$\% 0,1$ & r & الخيف \\
\hline$\% 0,1$ & $r$ & السربع \\
\hline$\% r, 0$ & 1 & مجزوء الرجز \\
\hline
\end{tabular}

مجموع القصائد 9 ب قصيدة

فـآلام المعتمـــ وتوجعاتهـه هـى التـى جعلـت لسـانه فياضـا ينسـال بالمعـانى

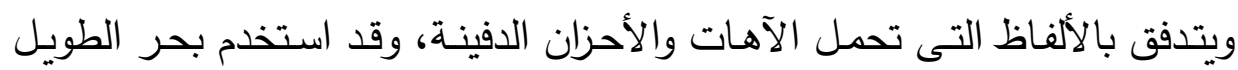

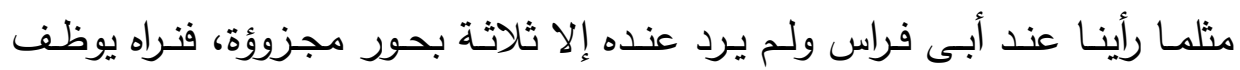
موسيقى بحر الطويل قائلاً:

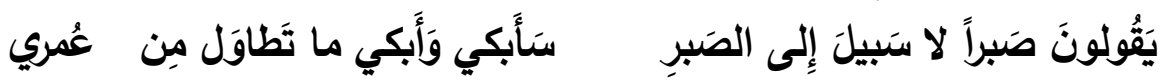

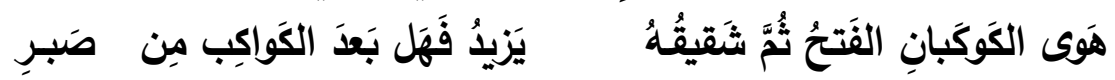

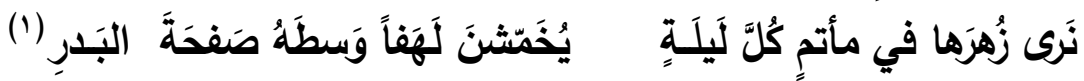


الاغتراب بين أبى فراس والمعتمد بن عباد - دراسة وموازنة - مرك

فنرى حروف المد تتوالى راسمة حالة من الامتداد والطول الذى عانى منـه

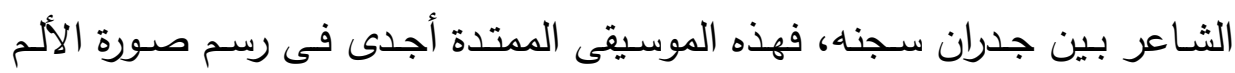
الذى يشعر به المعتمد.

ونرى البحور المجزوءة عنده موظفة فى مكانها، فحينما حلت الكارثة بملكه

كان السقوط مفاجئًا كاسراً فقال:

وتنبه القلب الصديع

فليبدُ مِنك لَهُمْ خُضوعُ الهُع (1)

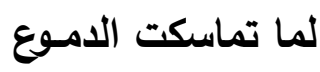

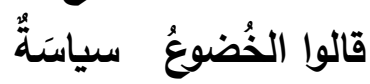

ولعل إيقاع حرف العين رسم الصورة بصورة جيدة، وهذه القصيدة أطول من القصيدتين الأخريتين مما يدلل على عزوفه عن البحور المجزوه.

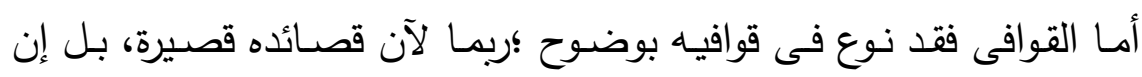

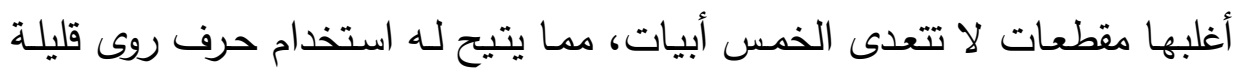

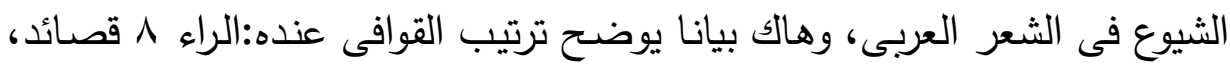

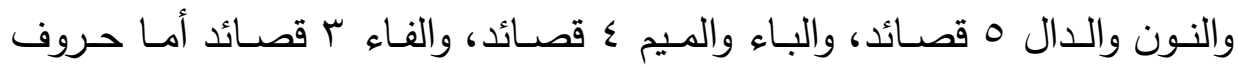

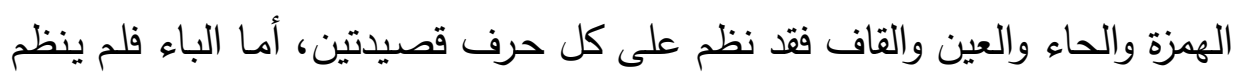

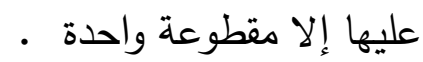

ورغم أن المعتمد كان يكتب أبياتاً قليلة العدد، إلا أنها كانت تحمل زفرات

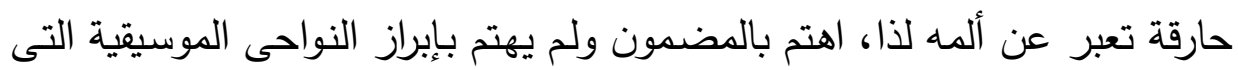

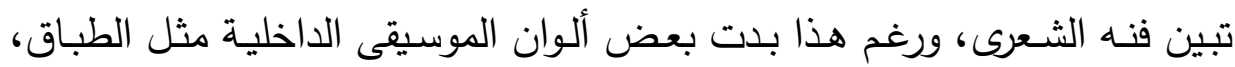
فقال:

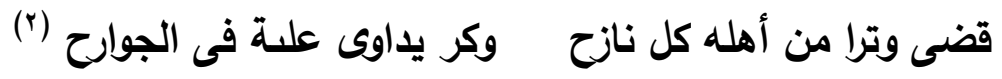

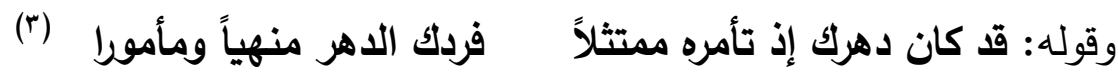
واستخدم التصريع فى قوله:

كلامك حر والكلام غلام وسحر ولكن ليس فيه حرام (1) (1) السابق ص ^1.

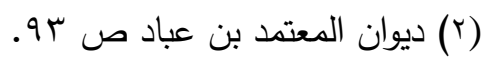

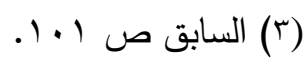


الاغتراب بين أبى فراس والمعتمد بن عباد - دراسة وموازنة -

واستخدم التقفية فى قوله:

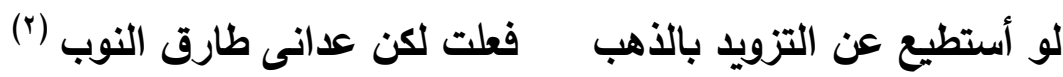
وملامح الجودة فى هذا اللون التصويرى الموسيقى بارعة عند شاعرينا حيث كشفا عن وجدانهما وعاطفتهما بصورة مميزة.

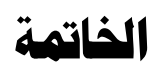

ا ـ وقد امتاز شعر الاغتراب ـ غالباً بصدق العاطفة، وأصالة التجربة فى الديوان

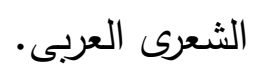

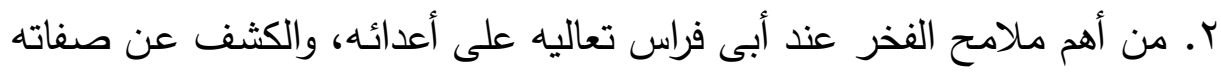

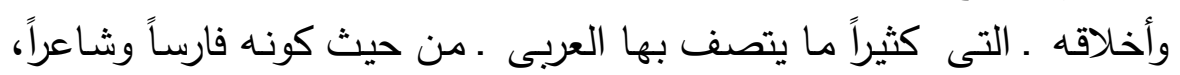

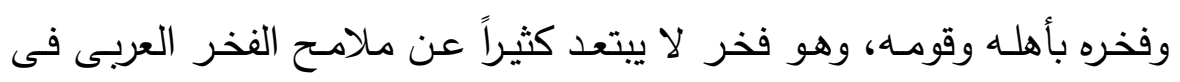

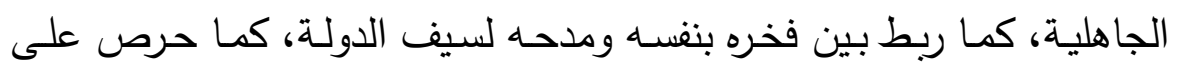

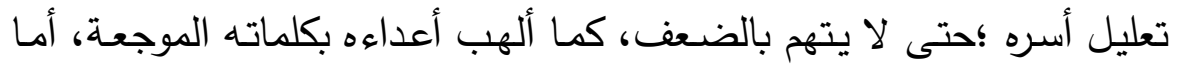

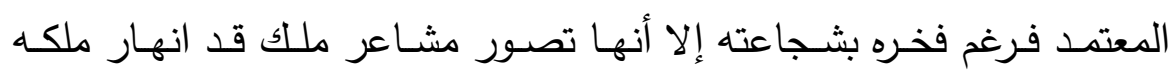

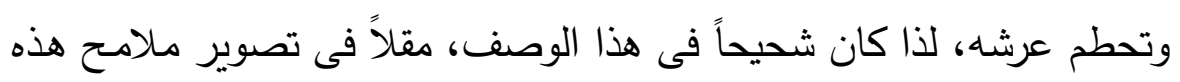

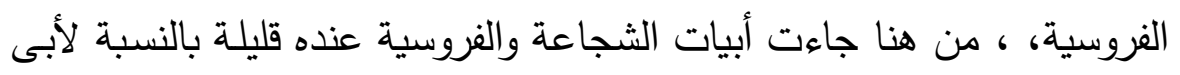
فراس الذى عنى عناية بالغة بتصوير فروسيته النيات النادرة.

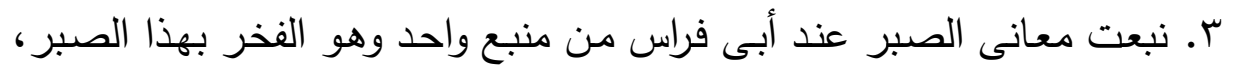

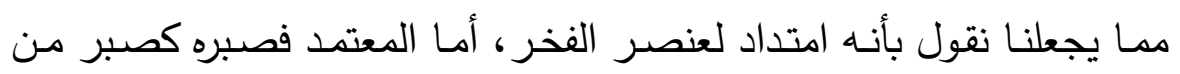

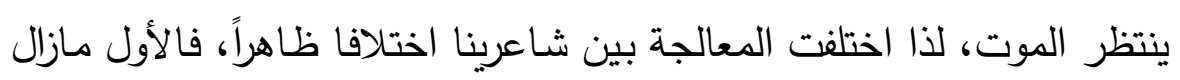
ملك قومه قائما، أما الآخر : فقد زال ملكه، من هنا اختلفت أصداء التجربة. 
الاغتراب بين أبى فراس والمعتمد بن عباد - دراسة وموازنة

ء. رسم الحمدانى صورة مؤلمـة من الثكوى على لسـان ملك فارس يتسم بالعزة والشأن الرفيع الذى يأبى أن يستكين أو يذل، أما المعتمد فقد كان أنس أكثر أنيناً

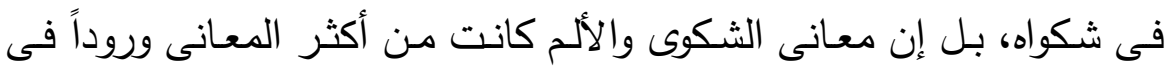

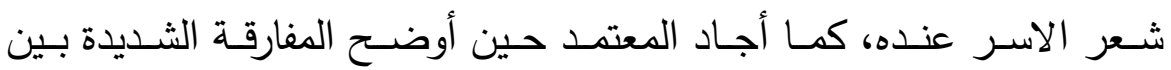

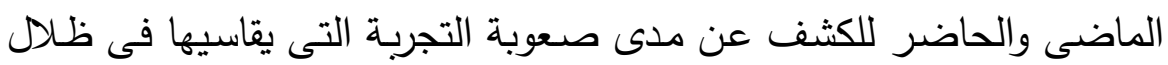
هذا السجن. ه. أن أبا فراس كان يستتجد سيف الدولة وكأنه يطلب العون من نفسه لنفسه أو

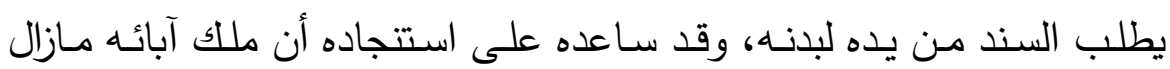

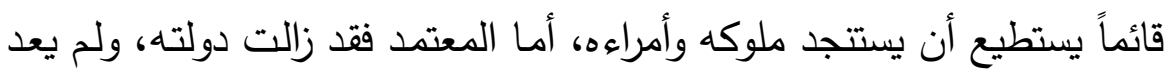

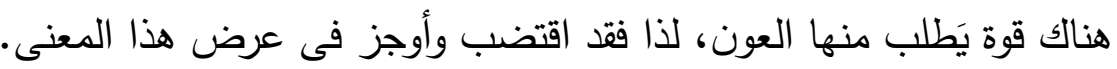
7. اتسم أبو فراس بسهولة الألفاظوالأساليب، أما المعتمد فقد كان أكثر غموضاً

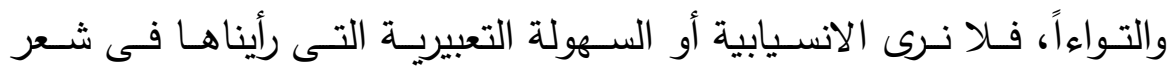
الحمدانى. V. كان أبو فراس أميل إلى السليقة والطبع فى معالجته للألفاظ من المعتمد الذى كان أكثر تقليداً للمشارقة.

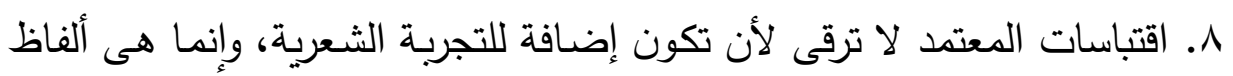
تتشابه بينه وبين من تناولوا المعنى قبله.

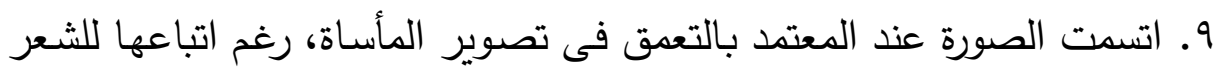
المشرقى فى أغلب الأحوال، فغلب فى لوحاته تصوير الدموع والحزن وبكاء

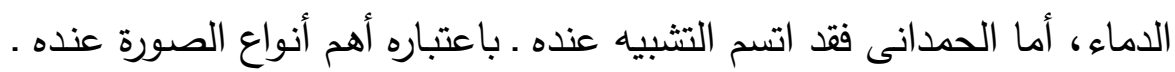
بالكشف عن الخصائص الشعورية لديه رغم تتوع الأغراض.

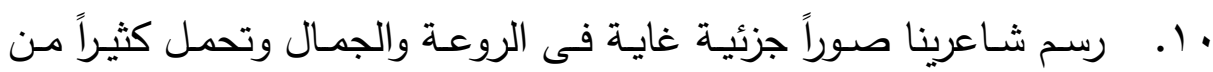

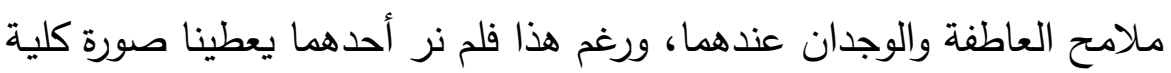

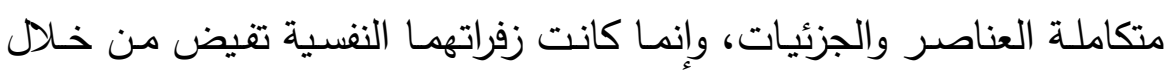




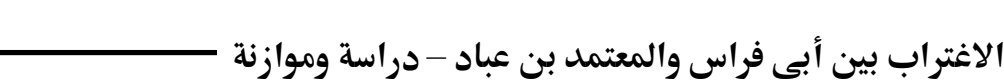

ا ا ـ وملامـح الجودة فى هذا اللون الموسيقى بارعة عند شـاعرينا حيث كشفا عن وجدانهما وعاطفتهما بصورة مميزة. 
الاغتراب بين أبى فراس والمعتمد بن عباد - دراسة وموازنة

\section{ثبت المسادر والمراجع}

ا ـ الأدب العربـى فـى الأتـدلس د/ عبـد العزبـز عتيـق دار النهضــة العربيـة للطباعة والنشر . للن

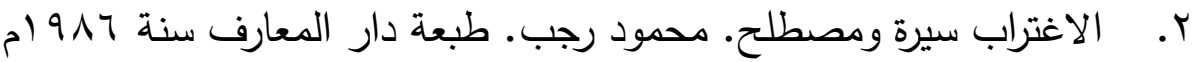

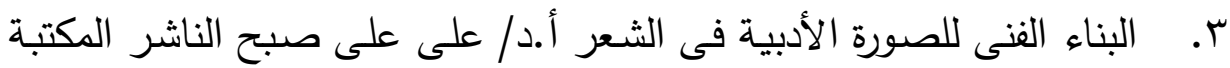

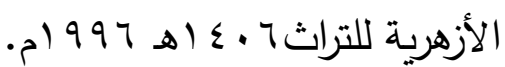
ـ. حركة التجديد الشعرى فى المهجر بين النظرية والتطبيق.د/عبد الحكيم بلبع.

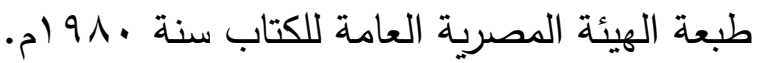

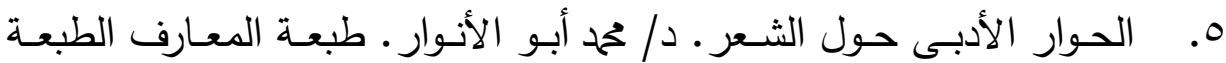

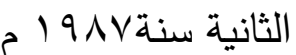
7 ـ خزانـة الأدب. للبغدادى تحقيق عبد السـلام هـارون دار الخـانجى الطبعـة

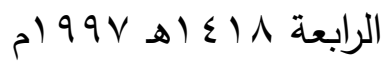
V. ديـوان ابـن الرومسى تحقيـق د/حسـين نصـار طبعـة دار الكتب والوثـائق

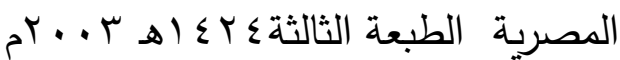

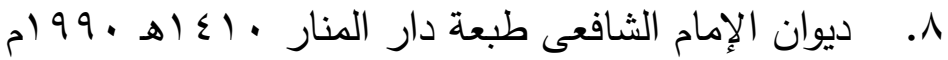
9 . ديوان أبو فراس شـرح وتقديم عباس عبد السـاتر طبعة دار الكتب العلميـة

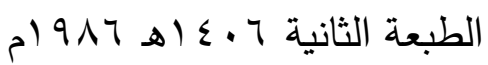

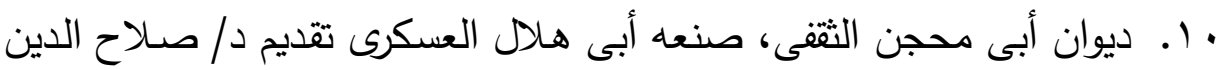

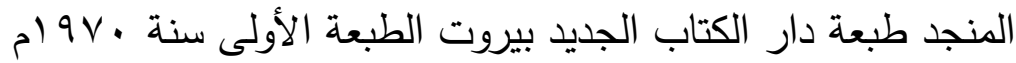

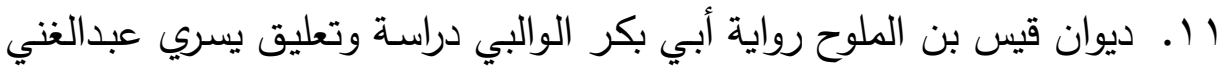

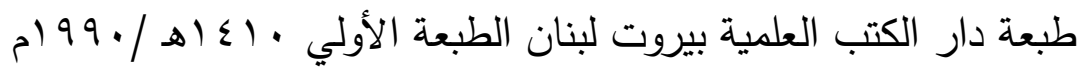
r ا. ديوان المتنبى طبعة صادر

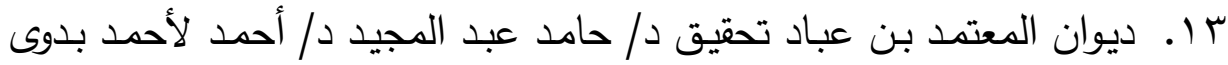

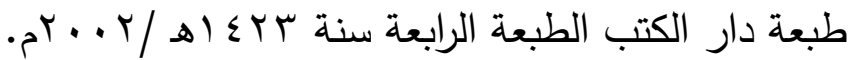

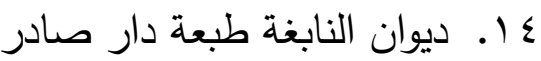




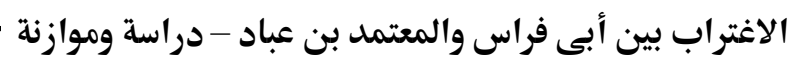

1 ا. الذخيرة فى محاسن أهل الجزيرة لابـن بسام تحقيق د/ إحسـان عباس دار

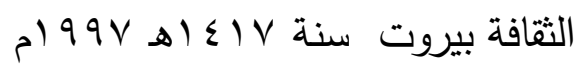

7 ا . شـاعر بنى حمدان د/أحمد بدوى مطبعـة الأنجلو المصرية الطبعـة الثانية

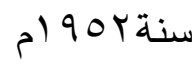

IV

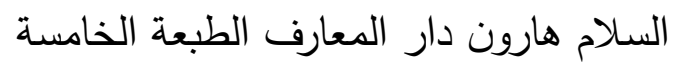

1 ا. الشعر بين الرؤيا والتشكيل د/ عبد العزيز المقالح دار العودة بيروت.

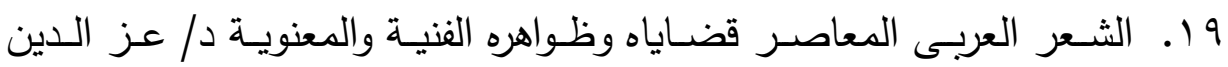
اسماعيل دار الفكر العربى.

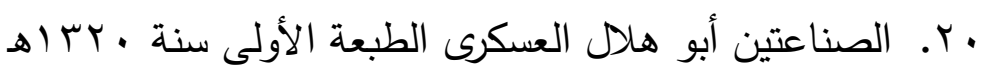
ا ا. عن بناء القصيدة العربية الحديثة د/ على عشرى زايد. دار مرجان للطباعة.

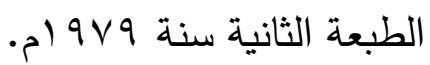

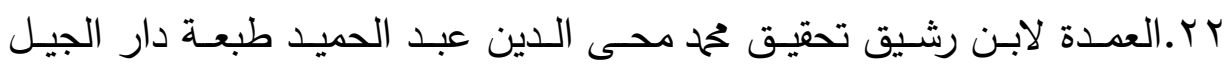

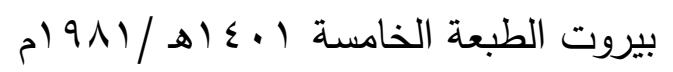

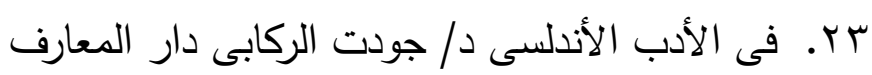

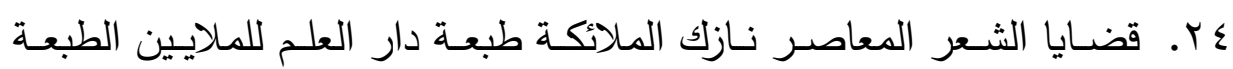
السابعة

هr. لسان العرب لابن منظور طبعة دار المعارف

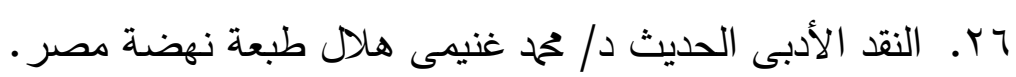
rV

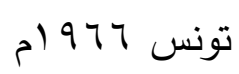

^r. وفيات الأعيان وأنباء أبناء الزمان، لابن خلكان، تحقيق د/ إحسان عباس دار صادر بيروت

9. . مجلـة كليـة الدراسـات الإسـلامية والعربيـة للبنـات بالمنصـورة عدد 17 سـنة r... $r \quad 1 \leq r \wedge$ 


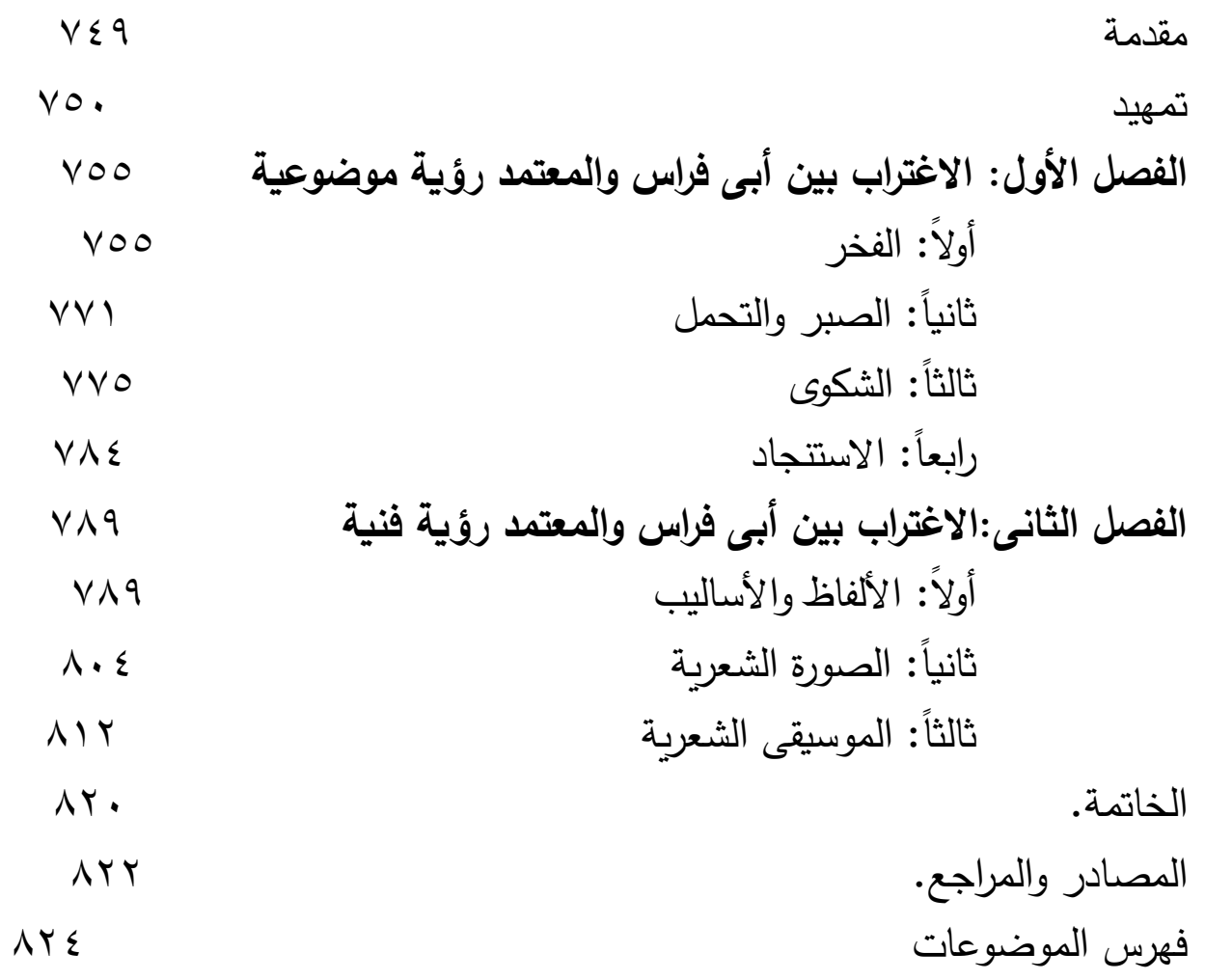

